\title{
PIPELINE CORRIDORS THROUGH WETLANDS - \\ IMPACTS ON PLANT COMMUNITIES: \\ MLL CREEK TRIBUTARY CROSSING, JEFFERSON COUNTY, NEW YORK, 1992 SURVEY
}

\section{TOPICAL REPORT}

(July 1992-July 1994)

\author{
Prepared by \\ G.D. Van Dyke,* L.M. Shem, and R.E. Zimmerman \\ Center for Environmental Restoration Systems \\ Energy Systems Division \\ Argonne National Laboratory \\ 9700 South Cass Avenue \\ Argonne, Illinois 60439
}

For

GAS RESEARCH INSTITUTE

Contract No. 5088-252-1770

GRI Project Manager

Ted A. Williams

Environment and Safety Research Group

December 1994

*Van Dyke is affiliated with the Department of Biology, Trinity Christian College, Palos Heights, Illinois. 
LEGAL NOTICE. This report was prepared by Argonne National Laboratory as an account of work sponsored by the Gas Research Institute (GRI). Neither GRI, members of GRI, nor any person acting on behalf of either:

a. Makes any warranty or representation, express or implied, with respect to the accuracy, completeness, or usefulness of the information contained in this report, or that the use of any apparatus, method, or process disclosed in this report may not infringe privately owned rights; or

b. Assumes any liability with respect to the use of, or for damages resulting from the use of, any information, apparatus, method, or process disclosed in this report. 


\section{DISCLAIMER}

This report was prepared as an account of work sponsored by an agency of the United States Government. Neither the United States Government nor any agency thereof, nor any of their employees, make any warranty, express or implied, or assumes any legal liability or responsibility for the accuracy, completeness, or usefulness of any information, apparatus, product, or process disclosed, or represents that its use would not infringe privately owned rights. Reference herein to any specific commercial product, process, or service by trade name, trademark, manufacturer, or otherwise does not necessarily constitute or imply its endorsement, recommendation, or favoring by the United States Government or any agency thereof. The views and opinions of authors expressed herein do not necessarily state or reflect those of the United States Government or any agency thereof. 


\section{DISCLAIMER}

Portions of this document may be illegible in electronic image products. Images are produced from the best available original document. 
50272-101

\begin{tabular}{|c|c|c|}
\hline $\begin{array}{l}\text { REPORT DOCUMENTATION } \\
\text { PAGE }\end{array}$ & $\begin{array}{l}\text { 1. REPORT NO. } \\
\text { GRI-94/0423 }\end{array}$ & 3. Recipient's Accession No. \\
\hline \multicolumn{2}{|l|}{ 4. Title and subtitle } & 5. Report Date \\
\hline \multirow{2}{*}{\multicolumn{2}{|c|}{$\begin{array}{l}\text { Pipeline Corridors through Wetlands - Impacts on Plant Communities: Mill } \\
\text { Creek Tributary Crossing, Jefferson County, New York, } 1992 \text { Survey }\end{array}$}} & December 1994 \\
\hline & & 6. \\
\hline \multicolumn{2}{|c|}{$\begin{array}{l}\text { 7. Author(s) } \\
\text { G.D. Van Dyke, L.M. Shem, and R.E. Zimmerman }\end{array}$} & 8. Performing Organization Rept. No. \\
\hline \multirow{2}{*}{\multicolumn{2}{|c|}{$\begin{array}{l}\text { 9. Performing Organization Name and Address } \\
\text { Center for Environmental Restoration Systems } \\
\text { Energy Systems Division } \\
\text { Argonne National Laboratory } \\
\text { 9700 South Cass Avenue } \\
\text { Argonne, Ill. } 60439\end{array}$}} & $\begin{array}{l}\text { 10. Projectraskwork Unit No. } \\
\text { ACK } 85872\end{array}$ \\
\hline & & $\begin{array}{l}\text { 11. Contract (c) or Grant (G) No. } \\
\text { (C) } 5088-252-1770 \\
\text { (G) }\end{array}$ \\
\hline \multirow{2}{*}{\multicolumn{2}{|c|}{$\begin{array}{l}\text { 12. Sponsoring Organization Name and Address } \\
\text { Environment and Safety Research Group } \\
\text { Gas Research Institute } \\
8600 \text { West Bryn Mawr Avenue } \\
\text { Chicago, Ill. } 60631\end{array}$}} & $\begin{array}{l}\text { 13. Type of Report \& Period Covered } \\
\text { Topical Report } \\
\text { July 1992-July } 1994\end{array}$ \\
\hline & & 14: \\
\hline
\end{tabular}

15. Supplementary Notes

\section{Abstract (Limit 200 words)}

The goal of the Gas Research Institute Wetland Corridors Program is to identify representative impacts of existing pipelines on the wetlands they traverse. To accomplish this goal, 12 existing wetland crossings were surveyed. These sites varied in elapsed time since pipeline construction, wetland type, pipeline installation techniques, and right-of-way (ROW) management practices. This report presents the results of the survey in July 1992 at Mill Creek tributary crossing, Jefferson County, New York. Data were collected from three wetland communities along the 1991 pipeline and compared with predisturbance data obtained in a June 1991 survey. Within one year after pipeline installation, $50 \%$ of the soil surface of the ROW in the scrub-shrub community was covered by emergent vegetation. Average wetland values for the ROW in 1992 were lower than in 1991, indicating that the removal of woody plants resulted in a community composed of species with greater fidelity to wetlands. In the emergent marsh community, after one year, the average percentage of surface covered by standing water was greater in the ROW than in the adjacent natural areas. The ROW in the forested wetland community also contained standing water, although none was found in the natural forest areas. The entire study site remains a wetland, with the majority of plant species in all sites being either obligate or facultative wetland species. Weighted and unweighted average wetland indices for each community, using all species, indicated wetland vegetation within the newly established ROW.

17. Document Analysis a. Descriptors

b. Identifiers/Open-Ended Terms

c. COSATI Field/Group

\begin{tabular}{|c|c|c|}
\hline $\begin{array}{l}\text { 18. Avallability statement } \\
\text { Release unlimited }\end{array}$ & $\begin{array}{l}\text { 19. Security class (this Report) } \\
\text { Unclassified }\end{array}$ & 21. No. of Pages \\
\hline & $\begin{array}{l}\text { 20. Security Class (this Page) } \\
\text { Unclassified }\end{array}$ & 22. Price \\
\hline
\end{tabular}




\section{Research Summary}

Title Pipeline Corridors through Wetlands - Impacts on Plant Communities: Mill Creek Tributary Crossing, Jefferson County, New York, 1992 Survey

Contractor

Principal Investigators

Report Period

Objective

Technical Perspective
Argonne National Laboratory

G.D. Van Dyke, L.M. Shem, and R.E. Zimmerman

July 1992-July 1994

Document the historical impacts of pipeline rights-of-way (ROWs) on wetlands.

The impact of pipeline construction in wetlands is a very sensitive issue and one that is under strict regulatory control. Neither the natural gas industry nor the regulatory community has a documented basis to define the type, value, or environmental consequences of past pipeline activities in wetlands. This is one of a series of reports documenting these impacts. This data report is the result of field studies in three wetland community types (scrub-shrub, emergent marsh, forested wetland) along a one-year-old pipeline in the state of New York. Plant data from this study are compared to data collected just prior to installation of the pipeline.

Results
Observable impacts of the ROW on hydrology and vegetation varied by community. In the scrub-shrub wetland community, the topography of the ROW was similar to that in the adjacent natural areas (NAs) unaffected by pipeline installation. In the forested wetland and the emergent marsh, a greater percentage of the ROW's surface was covered by standing water compared to the NAs. Within the scrub-shrub community, $50 \%$ of the ROW's surface was covered by emergent vegetation; lesser percentages were found in the emergent marsh and the forested wetland. In each community, the number of plant species occurring in the ROW was less than the number in the adjacent NAs. About $30 \%$ of the species occurring in the ROW in each community were not found in the NAs. The number of introduced species in the ROW compared to the NAs was much lower in the scrub-shrub community, somewhat lower in the emergent marsh, and slightly greater in the forested wetland. Reestablishment of vegetation on the ROW within the various 
communities was progressing rapidly without seeding or soil amendments.

Technical Approach

An attempt was made to select a relatively homogeneous study site within the scrub-shrub community and the emergent marsh. These sites occupied at least 150 meters along the ROW. Five transects were established across the ROW at each site for sampling. No such sites were available in the forested wetland, so a single transect was sampled within this community. Data were collected on soils, hydrology, and plant cover from transect plots within both sides of the ROW and within the NAs on either side of the ROW. Plant data were analyzed to determine similarities and differences between the two sides of the ROW and the two adjacent NAs.

Project Implications

This study shows that within one year after installation of the pipeline in this wetland (in 1991), vegetation had developed on the ROW within each of the three community types that included many species found in the adjacent NAs and collectively fewer introduced species than were present in the NAs. Vegetation was developing rapidly within the newly created ROW without seeding or soil amendments. Vegetation developing within the ROW consisted of wetland species. Further studies are needed to determine the length of time necessary for newly developing ROW plant communities to achieve the same level of diversity and total areal coverage as the plant communities in the adjacent NAs.

Ted A. Williams

GRI Project Manager

Environment and Safety Research Group 


\section{Contents}

Acknowledgment ................................................................

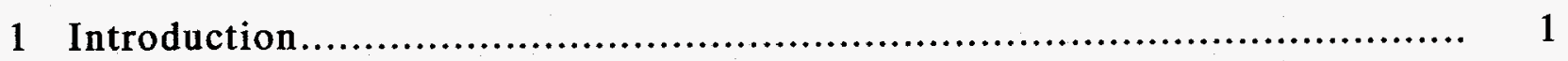

1.1 Background .................................................................... 1

1.2 Goals and Objectives......................................................... 2

2 Description of Study Area ...................................................... 4

2.1 Site Selection and Location ................................................... 4

2.2 Soils .............................................................................. 5

2.3 Hydrology ........................................................................ 7

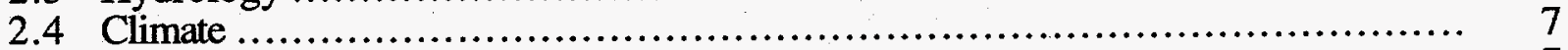

2.5 History and Management Practices .............................................. 7

3 Approach and Methods ...................................................... 9

3.1 General Approach ........................................................... 9

3.2 Habitat Description............................................................ 9

3.3 Sampling Design for Vegetational Studies .................................... 9

3.4 Data Analysis .............................................................. 14

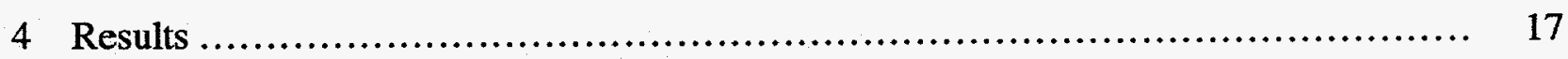

4.1 Scrub-Shrub Community.......................................................... 17

4.1.1 General Ecology .................................................... 17

4.1.2 Plant Community .................................................... 18

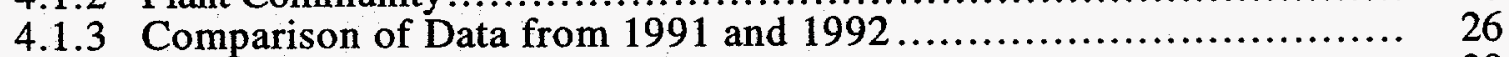

4.2 Emergent Marsh Community.......................................................... 30

4.2.1 General Ecology ..................................................... 30

4.2.2 Plant Community .......................................................... 30

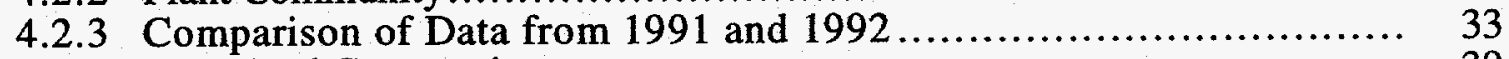

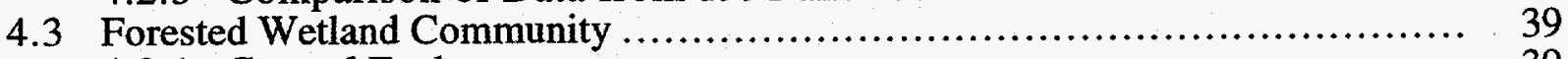

4.3.1 General Ecology ....................................................... 39

4.3.2 Plant Community ................................................ 41

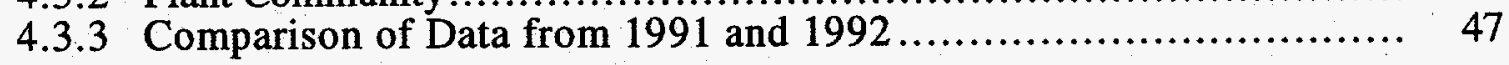

5 Discussion ............................................................... 52

5.1 Scrub-Shrub Community........................................................ 52

5.2. Emergent Marsh Community ..................................................... 53

5.3 Forested Wetland Community ................................................ 54

6 Summary and Conclusions..................................................... 56

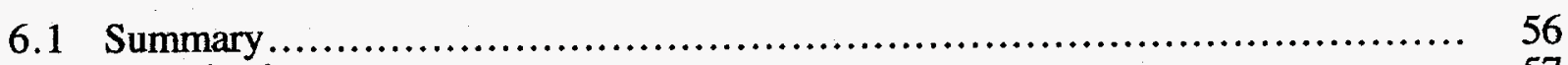

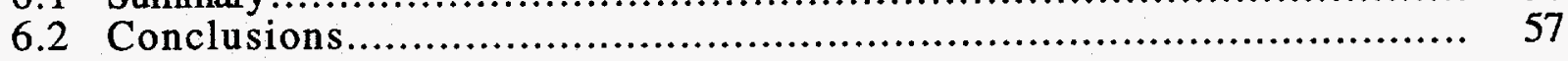

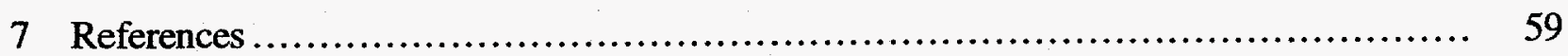




\section{Contents (Cont.)}

Appendix A： Definition of Jurisdictional Wetlands ............................... 61

Appendix B: Data Analysis — Definitions and Equations............................... 65

Appendix C: Plant Species List, Areal Coverage Data, and Species Distribution...... 71

Appendix D: Comparisons of Plant Species Found on Each Site:

1991 and 1992

\section{Figures}

1 Location of the Mill Creek Tributary Study Site in Jefferson County, New York.

2 Relative Locations of the Three Wetland Communities Studied

3 Generalized Cross-Section Showing the ROW, 1966 and 1991 Pipeline Locations, and Vegetation Types in the Scrub-Shrub Community.

4 Generalized Cross-Section Showing the ROW, 1991 Pipeline Location, and Vegetation Types in the Emergent Marsh Community

5 Generalized Cross-Section Showing the ROW, 1966 and 1991 Pipeline Locations, and Vegetation Types in the Forested Wetland Community.

6 Plan View Showing Belt Transects and Study Plot Sizes for the

Scrub-Shrub Community

7 Plan View Showing Belt Transects and Study Plot Sizes for the Emergent Marsh Community

8 Number of Plant Species in Each Wetland Indicator Category by Area in the Scrub-Shrub Community

9 Percentage of Species in Each Wetland Indicator Category by Area in the Scrub-Shrub Community

10 Number of Species in Each Wetland Indicator Category by Area in the Emergent Marsh Community

11 Percentage of Species in Each Wetland Indicator Category by Area in the Emergent Marsh Community

12 Number of Species in Each Wetland Indicator Category by Area in the Forested Wetland Community....

13 Percentage of Species in Each Wetland Indicator Category by Area in the Forested Wetland Community.... 


\section{Figures (Cont.)}

A.1 Schematic Diagram of the Wetland Delineation Process.

\section{Tables}

1 Number of Plant Species by Wetland Indicator Category Found in the Study Plots in the NAs and the ROW - Scrub-Shrub Community..............

2 Number of Plant Species by Wetland Indicator Category Found in the Study Plots in the North and South Sides of the ROW - Scrub-Shrub Community

3 Number of Plant Species by Wetland Indicator Category Found in the Study Plots in the NNA and SNA - Scrub-Shrub Community.

4 Dominant Species by Vegetative Stratum in Each Habitat Scrub-Shrub Community

5 Coefficient of Community Values Comparing Areas on the Basis of Species Composition - Scrub-Shrub Community

6 Prevalence Index and Average Wetland Values for All Species and Dominant Species Only in the NAs and the ROW

Scrub-Shrub Community

$7 \quad$ Number of Plant Species Present in 1991 Only, 1992 Only, and Both 1991 and 1992 by Wetland Indicator Category -

Scrub-Shrub Community

8 Coefficient of Community Values Comparing 1991 and 1992 Data on the Basis of Species Composition - Scrub-Shrub Community

9 Prevalence Index and Average Wetland Values for All Species and Dominant Species Only in the NAs and the ROW Scrub-Shrub Community

10 Number of Plant Species by Wetland Indicator Category Found in the Study Plots in the NAs and the ROW - Emergent Marsh Community

11 Number of Plant Species by Wetland Indicator Category Found in the Study Plots in the East and West Sides of the ROW - Emergent Marsh Community....

12 Number of Plant Species by Wetland Indicator Category Found in the Study Plots in the ENA and WNA - Emergent Marsh Community

13 Dominant Species by Vegetative Stratum for Each Habitat Emergent Marsh Community 


\section{Tables (Cont.)}

14 Coefficient of Community Values Comparing Areas on the Basis of

Species Composition - Emergent Marsh Community

15 Prevalence Index Values and Average Wetland Values for All Species and Dominant Species Only in the NAs and the ROW - Emergent

Marsh Community....

16 Number of Plant Species Present in 1991 Only, 1992 Only, and Both 1991 and 1992 by Wetland Indicator Category - Emergent Marsh Community.....

17 Coefficient of Community Values Comparing 1991 and 1992 Data on the

Basis of Species Composition - Emergent Marsh Community.

18 Prevalence Index and Average Wetland Values for All Species and Dominant Species Only in the NAs and the ROW - Emergent Marsh Community

19 Number of Plant Species by Wetland Indicator Category Found in the Study Plots in the NAs and the ROW - Forested Wetland Community

20 Number of Plant Species by Wetland Indicator Category Found in the Study Plots in the North and South Sides of the ROW - Forested Wetland Community.

21 Number of Plant Species by Wetland Indicator Category Found in the Study Plots in the NNA and SNA - Forested Wetland Community

22 Dominant Species by Vegetative Stratum - Forested Wetland Community.

23 Coefficient of Community Values Comparing Areas on the Basis of Species Composition - Forested Wetland Community.

24 Prevalence Index and Average Wetland Values for all Species and Dominant Species Only in the NAs and the ROW - Forested Wetland Community

25 Number of Plant Species Present in 1991 Only, 1992 Only, and Both 1991 and 1992 by Wetland Indicator Category - Forested Wetland Community........

26 Coefficient of Community Values Comparing 1991 and 1992 Data on the Basis of Species Composition - Forested Wetland Community...

27 Prevalence Index and Average Wetland Values for all Species and Dominant Species Only in the NAs and the ROW - Forested Wetland Community........

C.1 Plant Species List - Scrub-Shrub Community

C.2 Percent Areal Coverage Estimates by Stratum for Plant Species in the Scrub-Shrub Community.... 


\section{Tables (Cont.)}

C.3 Average Percent Coverage, Absolute Frequencies, and Distribution by Stratum for Plant Species in the Scrub-Shrub Community.

C.4 Plant Species List - Emergent Marsh Community

C.5 Percent Areal Coverage Estimates by Stratum for Plant Species in the Emergent Marsh Community

C.6 Average Percent Coverage, Absolute Frequencies, and Distribution by Stratum for Plant Species in the Emergent Marsh Community.

C.7 Plant Species List - Forested Wetland Community 89

C.8 Percent Areal Coverage Estimates by Stratum for Plant Species in the Forested Wetland Community

D.1 Plant Species Present in Study Plots in 1991 Only Scrub-Shrub Community.

D.2 Plant Species Present in Study Plots in 1992 Only -

Scrub-Shrub Community.

D.3 Plant Species Present in Study Plots in 1991 and $1992-$

Scrub-Shrub Community

D.4 Plant Species Present in Study Plots in 1991 Only Emergent Marsh Community

D.5 Plant Species Present in Study Plots in 1992 Only -

Emergent Marsh Community.

D.6 Plant Species Present in Study Plots in Both 1991 and 1992

Emergent Marsh Community .

D.7 Plant Species Present in Study Plots in 1991 Only -

Forested Wetland Community

D.8 Plant Species Present in Study Plots in 1992 Only -

Forested Wetland Community.

D.9 Plant Species Present in Study Plots in 1991 and $1992-$

Forested Wetland Community. 


\section{Acknowledgment}

Recognition is given to Dr. Dudley J. Raynal, a professor on the faculty of Environmental and Forest Biology, College of Environmental Science and Forestry, State University of New York, for assisting in field identification of plants and later verification of species identification of the plants found at the Mill Creek tributary site. 


\title{
Pipeline Corridors through Wetlands - \\ Impacts on Plant Communities: Mill Creek Tributary Crossing, Jefferson County, New York, 1992 Survey
}

by

\author{
G.D. Van Dyke, L.M. Shem, and R.E. Zimmerman
}

\section{Introduction}

\subsection{Background}

Pipelines for the distribution of natural gas traverse all types of terrain, including wetlands. Prior to the wetlands regulatory climate of the late 1980 s and the early 1990 s, the construction of right-of-way (ROW) corridors through wetlands was often welcomed by landowners and local communities; ROW corridors opened up wetlands, thereby providing public access. With the promulgation of more stringent regulations related to development activities (including no-net-loss wetland policies), an assessment of the historical impacts of pipeline ROWs through wetlands is needed to evaluate construction and reclamation methods, assist in future permit application processes, and evaluate future construction costs.

The Gas Research Institute (GRI) Wetland Corridors Program was designed to evaluate impacts of gas-pipeline construction and subsequent maintenance on wetlands. The data gathered through this GRI program provide a better understanding of the type, degree, and duration of impacts of various pipeline-construction techniques. This information will enable the industry to evaluate current construction practices and provide factual input to regulatory bodies.

Careful evaluation of the impacts of pipeline installation on wetlands is necessary because specific impacts may be beneficial to some plant and/or animal species and detrimental to others. Some impacts may appear to be detrimental when, in fact, they improve conditions for certain sensitive species or provide for greater diversity of species and habitat.

The initial questions addressed by the GRI Wetland Corridors Program are as follows:

1. Do ROW construction and/or management practices lead to differences in ROW plant communities with respect to adjacent wetland communities?

2. Does the ROW alter the diversity of the adjacent wetland community? If so, how far do the impacts extend?

3. Does the ROW enhance species diversity of the wetland? 
4. Are there ROW construction and management practices that can enhance the positive contributions of ROWs to wetlands and minimize detrimental impacts?

Answers to these broad questions will provide information related to a number of more specific questions. Data on the type of plant communities that develop on ROWs in various wetlands when specific pipeline construction and management practices are utilized and comparison of the ROW plant communities with the plant communities in areas adjacent to the ROW will provide a basis for comparing environmental impacts of previous and current construction and management practices. Valuable data for such comparisons include numbers of plant species present, species that are dominant, percentage of the species that are native to the area, and fidelity of the plants to wetlands. Other measures of the quality of species present are also valuable, but those data are not available at present.

Concern exists as to whether pipeline corridors provide avenues of access for nonnative and invasive plants. Whether such plants become established along pipeline ROWs and from there invade adjacent areas, and the extent to which such invaders modify the plant communities in adjacent areas, are important to determining potential impacts of pipelines on wetlands.

Potential positive impacts are also important to assess. The degree to which ROWs provide habitat for rare or endangered species and other desirable species that are poorly represented in the adjacent areas is important information. Assessments of impacts of pipeline corridors on wetlands should also include the contribution of corridors to both plant and animal species diversity.

Answers to the above questions will assist the industry and regulatory agencies in evaluating current installation and management practices and making modifications that are beneficial to wetland quality enhancement.

\subsection{Goals and Objectives}

The goal of the GRI Wetland Corridors Program is to document impacts of existing pipelines on the wetlands they transverse. To accomplish this goal, 12 existing wetland crossings were surveyed. The sites evaluated differed in years since pipeline installation (ranging from 8 months to 31 years), wetland type, installation technology used, and management practices. Each wetland survey had the following specific objectives:

- Document vegetative communities existing in the ROW and in adjacent wetland communities;

- Evaluate similarities and differences between the plant communities in the ROW and in the adjacent wetland communities; 
- Document qualitative changes to the topography, soils, and hydrology attributable to ROW construction; and

- Identify impacts caused by ROW construction on rare, threatened, endangered, or sensitive species.

These individual wetland objectives were fulfilled by the collection and analysis of field data and the presentation of those data and their analysis in nine individual site reports. An upcoming summary report further synthesizes and interprets the data from all individual sites.

The following sections constitute a data report on a field survey conducted between July 7 and July 10, 1992, along a pipeline crossing of a wetland adjacent to the south-southwest boundary of the city of Watertown, New York. The wetland occupies the floodplain of a tributary of Mill Creek. The pipeline, installed in the summer of 1991, traverses several community types within the wetland. Data collected from the July 1992 field survey are compared with data collected in June 1991, before installation of the new pipeline. 


\section{Description of Study Area}

\subsection{Site Selection and Location}

In April 1991, personnel from a local power company assisted a team from Argonne National Laboratory (ANL) in selecting an area classified as "Jurisdictional Wetlands" under Section 404 of the Clean Water Act. (See Appendix A for information on jurisdictional wetlands.) The pipeline crossing in the Mill Creek tributary floodplain was selected because it included several types of wetland habitats. Figure 1 shows the location of the wetland adjacent to the southsouthwest boundary of the city of Watertown. The wetland is bordered by Holcomb Street on the west and extends along the city boundary for approximately $600 \mathrm{~m}^{*}$ east-southeast toward Washington Street.

This site was particularly interesting because of the opportunity it provided to collect data from an existing ROW, and to establish a pre-disturbance baseline for a planned second pipeline to be installed during the summer of 1991. Because the route of the planned pipeline joined the existing ROW approximately midway across the wetland, several different study areas were available: (1) an emergent marsh along the planned pipeline; (2) the existing pipeline, which would not be affected by installation of the planned pipeline; and (3) one or more sites along the existing pipeline where the planned pipeline would be installed on the same ROW.

The pipeline company personnel expressed interest in conducting baseline and follow-up studies on innovative installation techniques planned for the emergent marsh. These techniques would involve removing the vegetative mat intact and replacing it (with minimal disturbance) following pipeline installation.

The existing pipeline ROW, with its 8-in. (20-cm)-diameter pipeline, was constructed in 1966. Three sites along this ROW and one additional site in the emergent wetland along the ROW of the planned pipeline were sampled in early June 1991. Results of that study are presented in a separate report (Van Dyke et al. 1994).

The new 12-in. (30.5-cm)-diameter pipeline was installed during the summer of 1991. Figure 2 illustrates the locations of the 1966 and 1991 pipelines as they traverse the wetland. The north-south segment of the 1991 pipeline ROW passes through about $200 \mathrm{~m}$ of emergent cattail marsh before it enters a scrub-shrub community about $30 \mathrm{~m}$ north of the 1966 pipeline ROW. From the junction of the two pipeline ROWs, the 1991 pipeline follows the 1966 pipeline ROW east-southeast until it exits the wetland. The first $150 \mathrm{~m}$ of the ROW containing both pipelines passes through a scrub-shrub community that intergrades into a forested wetland community, which in turn intergrades into a lowland forest.

\footnotetext{
* Measurements are given in metric units except where they were actually made in English units; in these cases, metric equivalents are given in parentheses.
} 


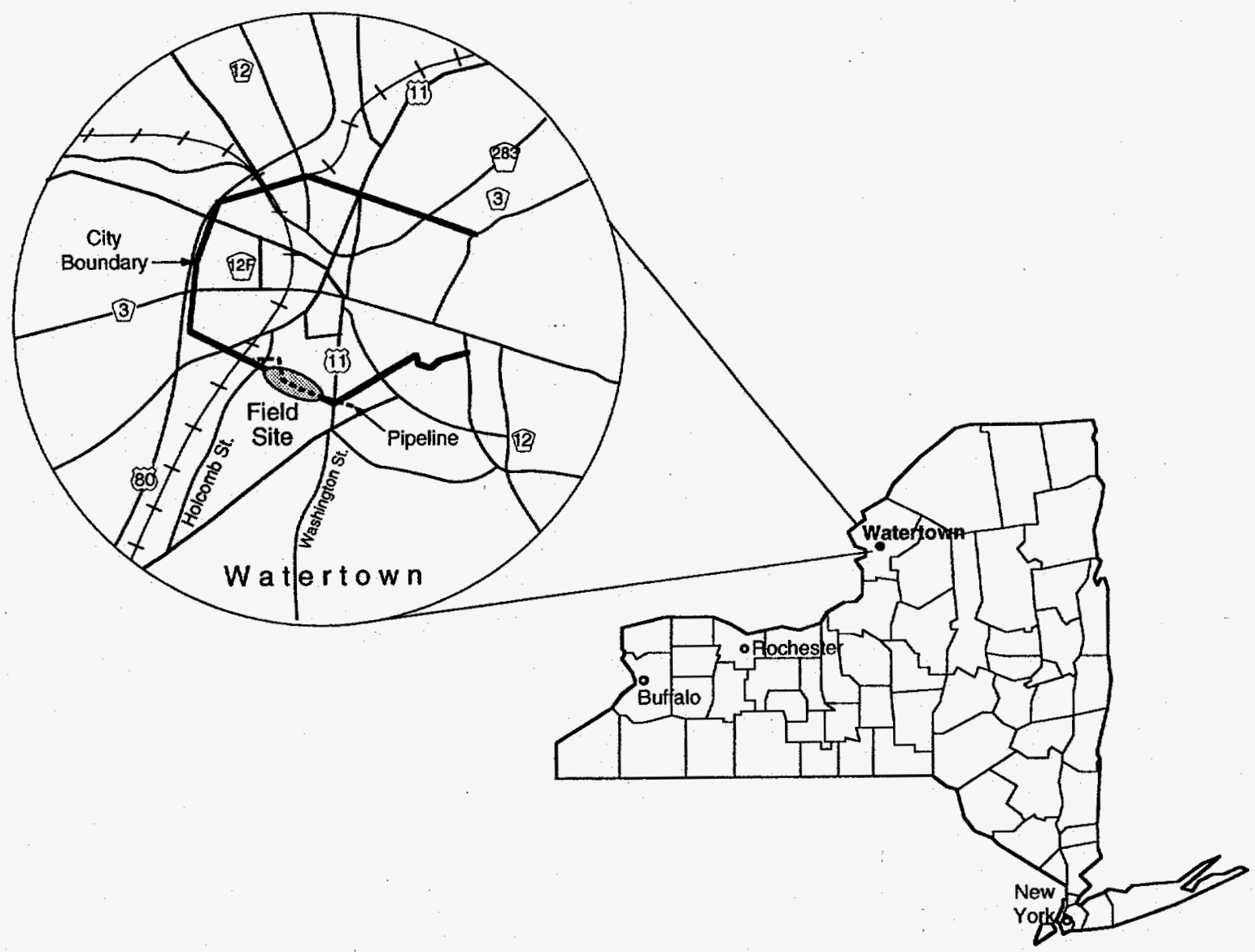

FIGURE 1 Location of the Mill Creek Tributary Study Site in Jefferson County, New York

\subsection{Soils}

The soils found at the subject wetland consisted mainly of four types: Lamson fine sandy loam, Canadaiqua silt loam, Minoa fine sandy loam, and Palms muck (Soil Conservation Service [SCS] 1989). The soils at the study sites consisted of mostly Lamson soils, which are very deep, poorly to very poorly drained soils that formed in stream- or lake-laid sediments and are dominated by fine to very fine sand. Canadaiqua soils are very deep, poorly to very poorly drained soils that formed in lake deposits on glacial lake plains. Minoa soils are very deep, somewhat poorly drained soils that formed in water-sorted sediments and are dominated by fine to very fine sand. Palms muck soils are very poorly drained soils that formed in deposits of organic materials, 16 to 50 in. thick, over loamy mineral soil deposits in bogs and depressions on lake plains, till plains, and outwash plains. All four of these soil types are found in areas with slopes ranging from 0 to 3 in. $(0$ to $8 \mathrm{~cm})$. All but Minoa are listed as hydric soils in Hydric Soils of the United States (SCS 1991). 


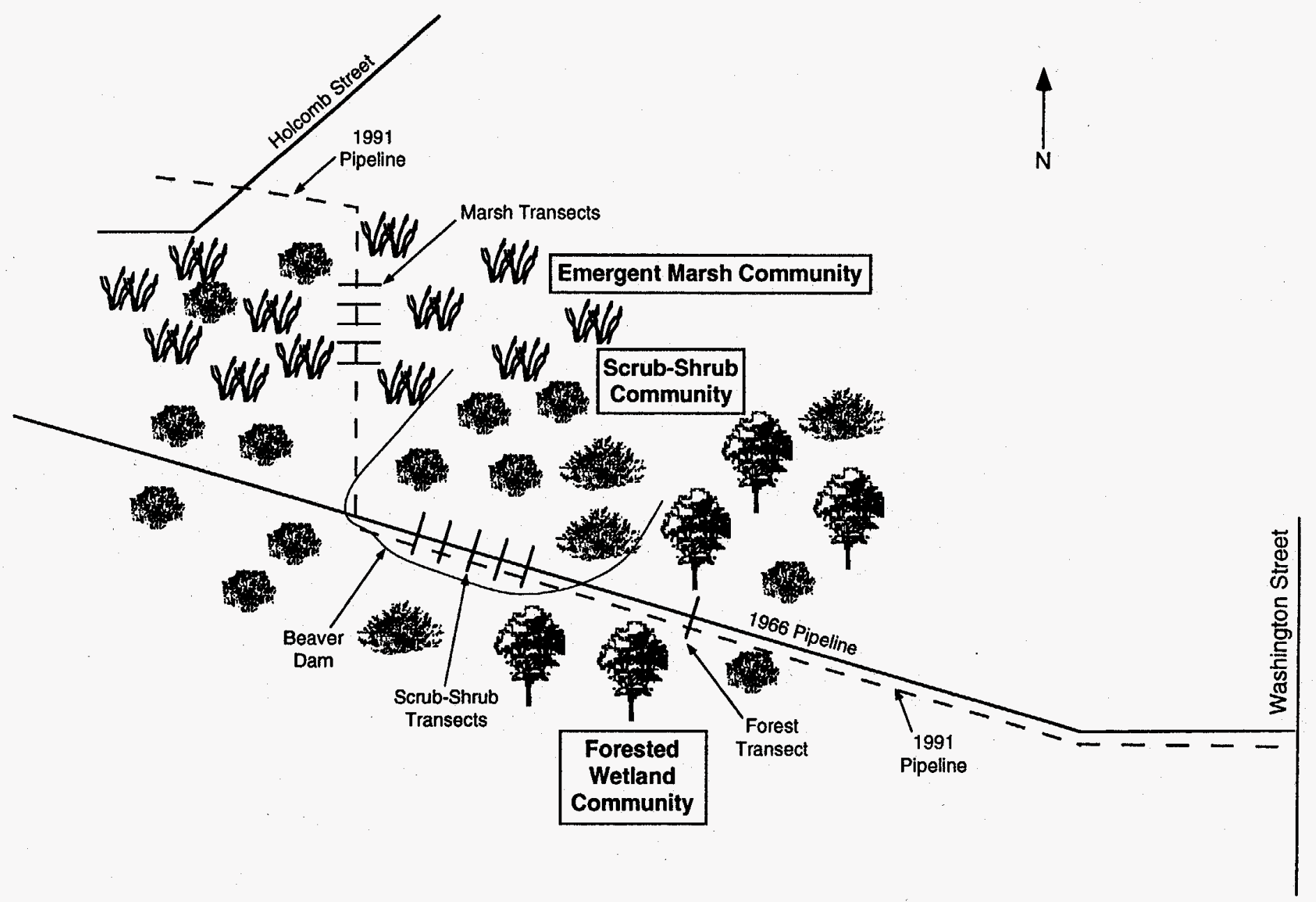

a

FIGURE 2 Relative Locations of the Three Wetland Communities Studied 


\subsection{Hydrology}

The soil surface of the wide valley floor along the route of the 1966 pipeline shows little relief from its western edge, just east of Holcomb Street, for about $400 \mathrm{~m}$, until it slopes upward very gradually to its forested eastern edge. There are no well-defined drainage channels in the valley floor. Sheet water flow is from north-northeast to south-southwest, crossing the pipeline ROW at a right angle. Sewage effluent is discharged into the wetland at its western edge near the pipeline ROW.

Although attempts have been made to improve drainage, and the wetland has been drained in the past, water levels at the pipeline crossing are presently at or above the soil surface in much of the wetland throughout most of the year. An extensive U-shaped beaver dam maintains standing water over an area measuring approximately $100 \mathrm{~m} \times 100 \mathrm{~m}$ just east of the center of the wetland along the ROW. The location of this dam is shown in Figure 2.

\subsection{Climate}

Jefferson County has a temperate climate of cold winters and moderately warm summers with occasional hot spells (SCS 1989). The average winter temperature is $21^{\circ} \mathrm{F}\left(-6^{\circ} \mathrm{C}\right.$ ) and the average daily minimum temperature is $12^{\circ} \mathrm{F}\left(-11^{\circ} \mathrm{C}\right)$. The lowest recorded temperature at Watertown is $-32^{\circ} \mathrm{F}\left(-35^{\circ} \mathrm{C}\right)$. Summer temperatures average $68^{\circ} \mathrm{F}\left(20^{\circ} \mathrm{C}\right)$ with average daily highs of $77^{\circ} \mathrm{F}\left(25^{\circ} \mathrm{C}\right)$. The highest recorded temperature at Watertown is $97^{\circ} \mathrm{F}\left(36^{\circ} \mathrm{C}\right)$.

Total annual precipitation is 40 in. $(101.6 \mathrm{~cm})$, which is distributed fairly evenly throughout the year and is almost always adequate for all crops. Monthly precipitation ranges from 2.65 to 4.01 in. $(6.73$ to $10.19 \mathrm{~cm})$; the lower range occurs in the late winter and the higher range in the late summer and fall. The average seasonal snowfall is $101 \mathrm{in}$. $(256.5 \mathrm{~cm})$.

In nine out of ten years, the growing season ranges from 122 to 181 days, depending on the daily minimum temperature. In one out of ten years, the growing season ranges from 173 to 234 days.

\subsection{History and Management Practices}

Area History. The wetland area, designated as "W-2" on the New York State Department of Transportation (NYSDT) map for Jefferson County (NYSDT 1986), is described in the pipeline application permit to the U.S. Army Corps of Engineers as an emergent wet meadow with an outer area consisting of abandoned hayfields that are presently used for septic disposal. A verbal account of the wetland's history was given by Tim Wright (Wright 1991). Wright indicated that the area had been partially drained by plowed furrows along the drainage gradient to allow pasturing during the 1950 s and 1960s. Following the construction of nearby Interstate Highway 
81 (in approximately 1960), the water levels were elevated and the natural vegetation was allowed to grow back. Water levels in the area have been further elevated by an extensive series of beaver dams. Most of those dams are less than 20 in. $(50.8 \mathrm{~cm})$ in height.

Pipeline Construction. The existing 8-in. (20.3-cm)-diameter pipeline was installed in 1966, using the conventional methods of the time. Specific information on the construction methods was not available. However, if typical pipeline industry guidelines were followed, it is likely that the slash from clearing the area was used as corduroy and support pads were used in wetland areas. Information was not available on any maintenance activity that may have occurred on the ROW from 1966 to 1991. During our June 1991 survey, it appeared that little or no maintenance had been performed at this site, except for hand-clearing of a few shrubs to facilitate recent survey work in the ROW.

Construction of the 12-in (30-cm)-diameter 1991 pipeline was started during the last week of June and completed by the end of August. Slash from the scrub-shrub and the forested wetland areas provided support for the backhoe used to excavate the ditch and for the heavy equipment used for pipeline fabrication and installation. Support pads were brought in for use in the emergent wetland. Plans called for keeping sections of the emergent vegetation mat intact during excavation and backfilling. 


\section{Approach and Methods}

\subsection{General Approach}

The primary objectives listed in the Introduction (Section 1.2) provided the general guidelines for this study. To allow comparison of results across sites, methodologies for site reconnaissance, vegetation data collection, and data analysis used at this site were similar to those used at the other sites.

The initial sampling of the four vegetative communities in this wetland occurred during early June 1991 (Van Dyke et al. 1994). Resampling of three of these communities - the scrubshrub community, the emergent marsh, and the forested wetland - was completed during July 1992 to evaluate the impacts from the installation of the new pipeline through these communities during late June and July 1991. The general approach in 1992 was the same as in 1991 to allow comparison of data from the two sampling periods.

\subsection{Habitat Description}

General site data including topography, water levels, water flow direction, soil surface conditions, and ROW characteristics were recorded based on general reconnaissance of the sites. ROW boundaries were identified on the basis of survey flags remaining at the northern edge of the ROW and on width measurements.

Figure 3 depicts a generalized cross-section of the scrub-shrub vegetation along a northsouth line perpendicular to the 1966/1991 ROW. The vegetation ranged from mostly shrubs north of the ROW to mostly saplings and small trees south of the ROW. Shallow, standing water was maintained throughout the scrub-shrub area by a low, extensive beaver dam. The scrub-shrub community intergraded eastward into a forested wetland that soon intergraded into a lowland forest. Figure 4 is a generalized cross-section of the emergent marsh vegetation along an eastwest line perpendicular to the 1991 ROW. A generalized north-south cross-section of the vegetation at the 1966/1991 forested wetland ROW site is shown in Figure 5.

\subsection{Sampling Design for Vegetational Studies}

At each of the three study sites, four sampling areas were defined on the basis of their relationship to the ROW: the two sides of the ROW on either side of the ROW midline, and the two adjacent natural areas (NAs), undisturbed by pipeline installation, on either side of the ROW. Defining these four areas allows for comparisons between the two vegetative communities in the 


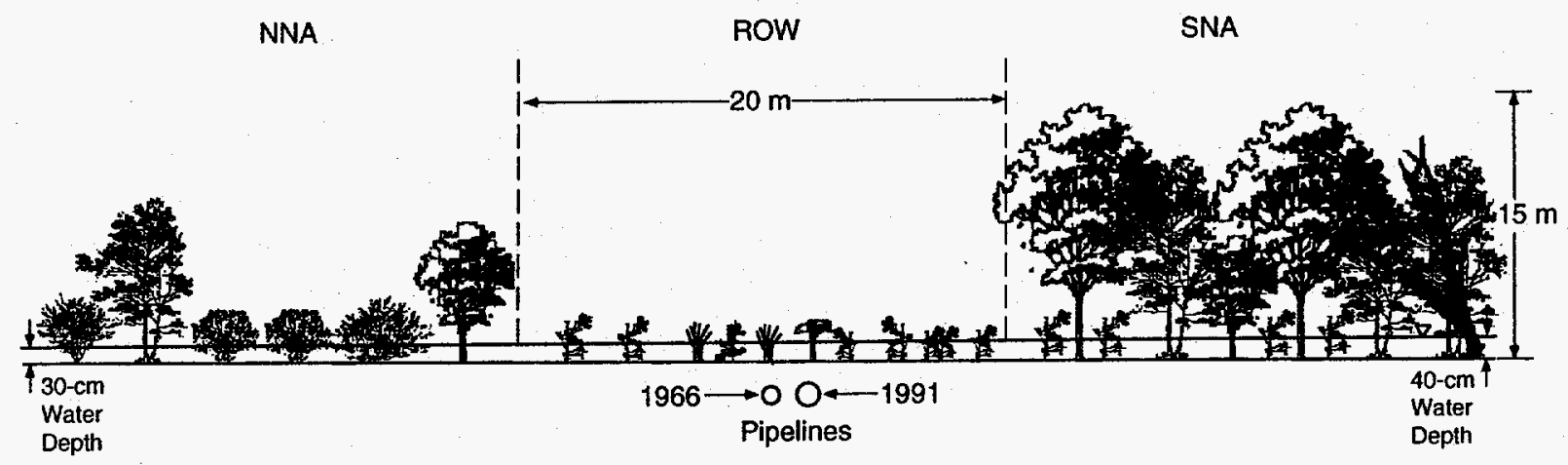

FIGURE 3 Generalized Cross-Section Showing the ROW, 1966 and 1991 Pipeline Locations, and Vegetation Types in the Scrub-Shrub Community

WNA

ROW

ENA

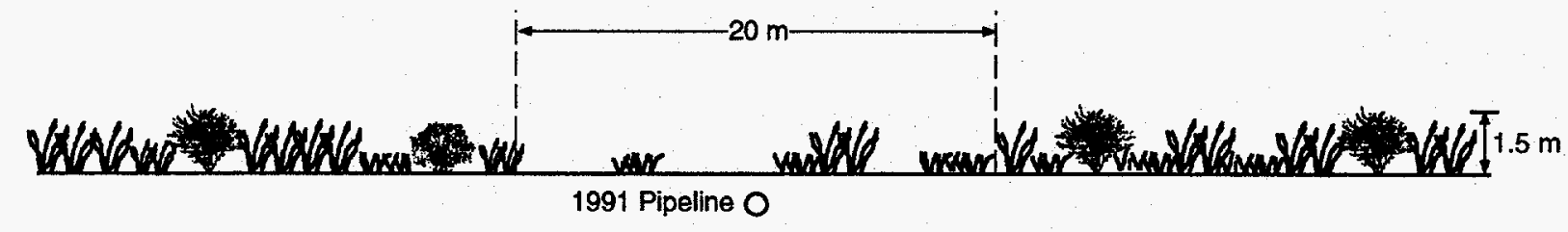

FIGURE 4 Generalized Cross-Section Showing the ROW, 1991 Pipeline Location, and Vegetation Types in the Emergent Marsh Community

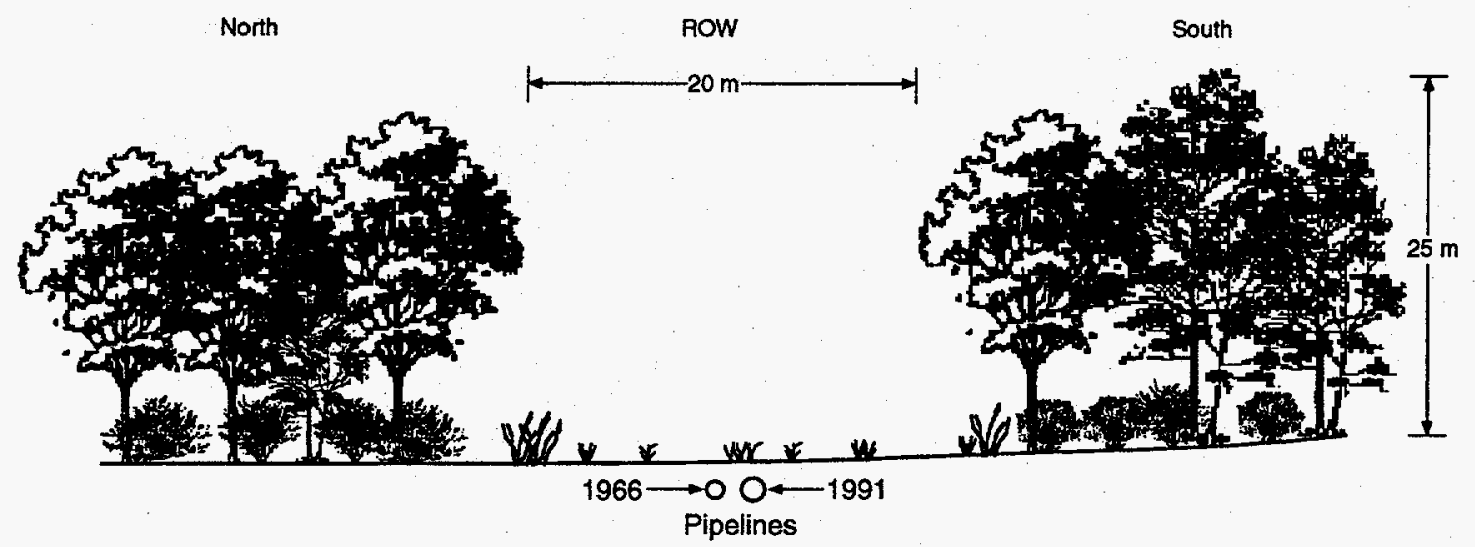

FIGURE 5 Generalized Cross-Section Showing the ROW, 1966 and 1991 Pipeline Locations, and Vegetation Types in the Forested Wetland Community 
NAs, the vegetative communities developing on the two sides of the ROW, and the vegetative communities developing on the ROW and those occurring in the NAs. For convenience, these four sampling areas are designated at each site by their direction from the midline of the ROW.

Transects. Sampling sites were established in each of the three communities. Figure 2 shows the locations of the scrub-shrub, emergent marsh, and forested wetland communities.

Scrub-Shrub Site. A primary sampling site was established along the 1966/1991 pipeline ROW within the scrub-shrub community. Five stations were established, at 30-m intervals, along the center of the ROW at this site. The first, the westernmost station, was randomly located within the scrub-shrub community near the western edge. At each station, $60-\mathrm{m}$-long transects perpendicular to and centered on the existing pipeline were established. Five belt transects, each $20 \mathrm{~m}$ wide and $60 \mathrm{~m}$ long, were established by using the station transects as a centerline for each belt transect. Each belt transect was divided into four segments: the north and south sides of the ROW, represented by $10-\mathrm{m}$ segments on either side of the ROW midline, and the north natural area (NNA) and south natural area (SNA), represented by the segments between 10 and $30 \mathrm{~m}$ from the center of the ROW. Plot sizes were $10 \mathrm{~m} \times 20 \mathrm{~m}$ in the ROW and $20 \mathrm{~m} \times 20 \mathrm{~m}$ in the NAs. Figure 6 shows the layout of the five transects (T1 through T5) and plots. Figure 2 shows the location of the transects.

Emergent Marsh Site. A second primary site was established in the emergent marsh community along the 1991 pipeline ROW. As at the scrub-shrub site, five stations were established at 30-m intervals; the first (northernmost) station was located randomly along the ROW at a sufficient distance (approximately $80 \mathrm{~m}$ ) into the marsh to avoid wetland edge effects. At each station, a 60-m transect was established perpendicular to the midline of the ROW. Five belt transects, each $10 \mathrm{~m}$ wide, were established by using each of the station transects as a northern boundary. Each belt transect was divided into four segments. Two $10-\mathrm{m} \times 10-\mathrm{m}$ segments, consisting of the first $10 \mathrm{~m}$ on either side of the ROW midline, were used as the sampling plots to collect data on the ROW. The outer two $10-\mathrm{m} \times 20-\mathrm{m}$ segments, extending from 10 to $30 \mathrm{~m}$ on either side of the ROW midline, were used as the sampling plots to provide data on the NAs undisturbed during pipeline installation. Figure 7 shows the layout of these transects and plots. Figure 2 shows the locations of the five transects.

Forested Wetland Site. The third sampling area, a secondary site consisting of a single station, was established in the forested wetland east of the scrub-shrub community, along the 1966/1991 pipeline ROW. A single station was used in this community because an insufficient uniform area was available for multiple stations. The terrain gradually increased in elevation along the ROW from west to east after exiting the scrub-shrub community. A station was randomly located approximately $100 \mathrm{~m}$ east of the nearest transect in the scrub-shrub community, in approximately the same area sampled in 1991. The transect and four sampling plots were established using the same procedures and dimensions as those used in the scrub-shrub community. Figure 2 shows the location of the transect. 


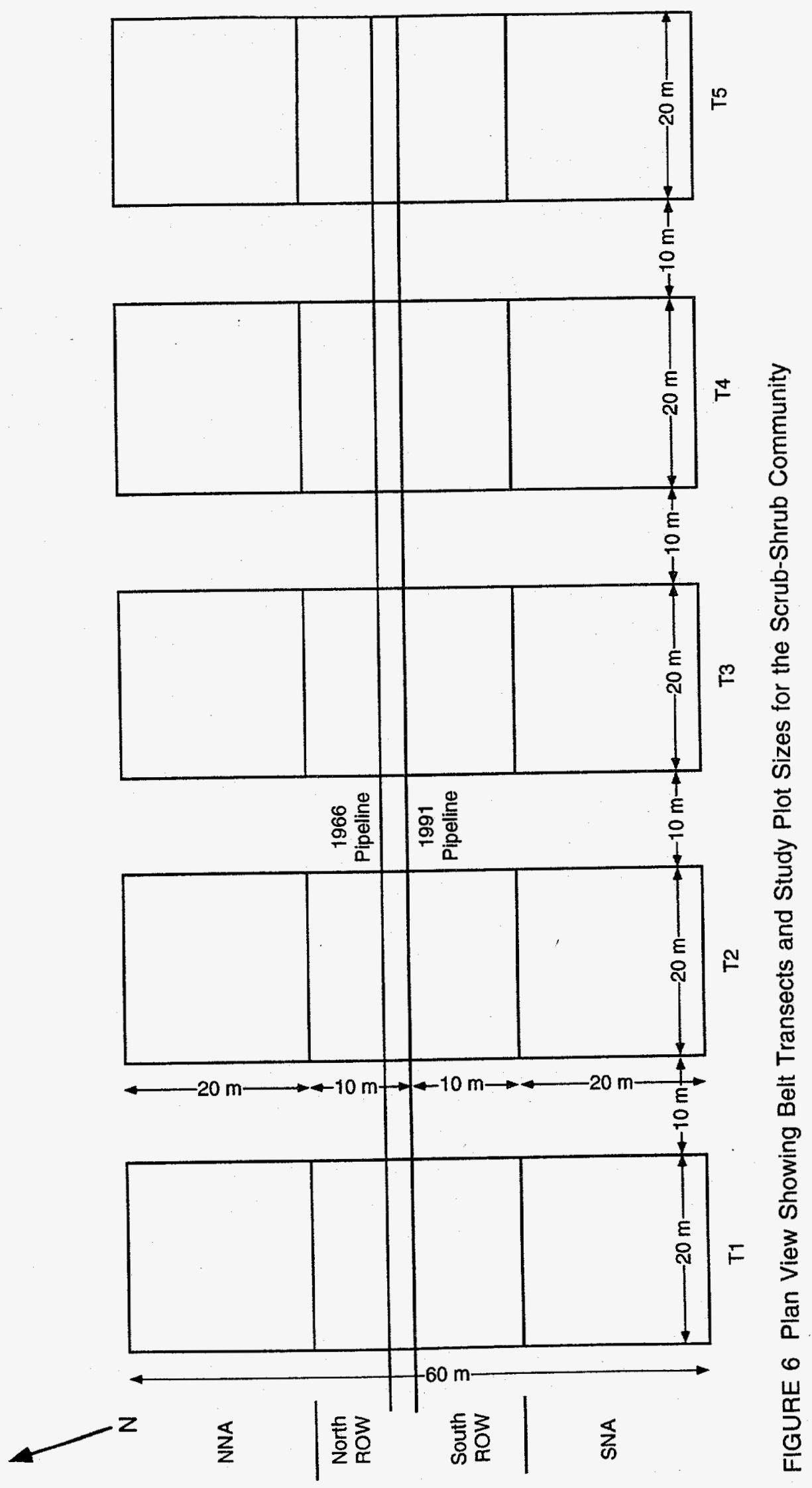




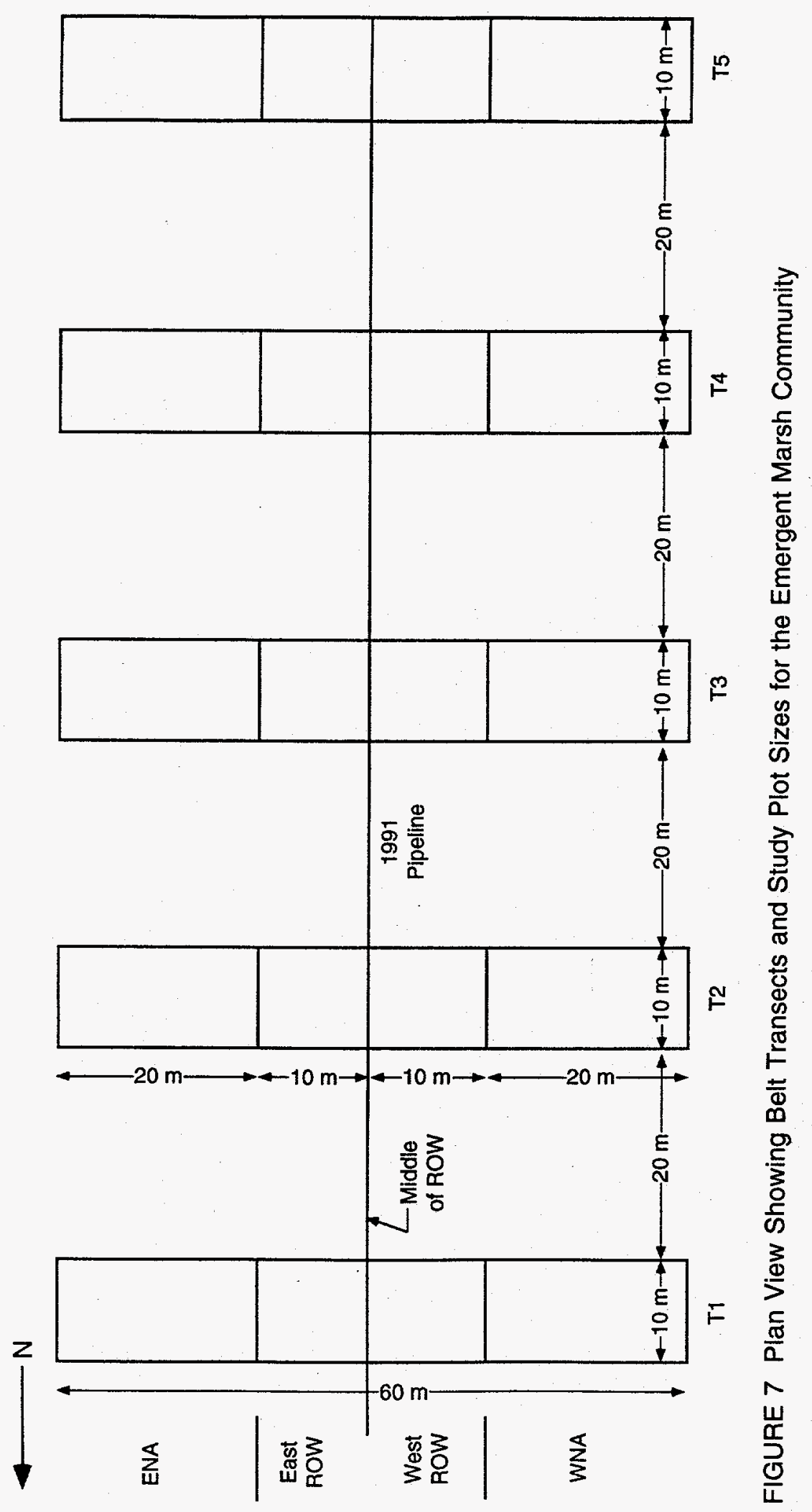


Sampling Procedures. Vegetational data were collected in July 1992 on each of the measured plots at each of the three sites. Two specimens of each plant species (found on or near the plots) that had not been collected in 1991 were collected as voucher specimens. Plant names, wetland indicator categories, life-forms, and the origin of each species were derived from the national list of plant species (Reed 1988). Vegetational data were collected using areal coverage estimates within sampling plots. At each site, estimates were made separately for the herb stratum, the shrub stratum, the sapling stratum, and the tree stratum, as defined in the 1989 Federal Manual for Identifying and Delineating Jurisdictional Wetlands (FICDW 1989), hereafter referred to as the "Federal Manual." Herbs are defined as herbaceous plants, including graminoids, forbs, ferns, herbaceous vines, and woody species under $3 \mathrm{ft}(1 \mathrm{~m})$ in height. Shrubs include multistemmed bushy shrubs, small saplings, and trees between $3 \mathrm{ft}$ and $20 \mathrm{ft}(.91 \mathrm{~m}$ and $6.1 \mathrm{~m})$ in height. Saplings are defined as having a diameter at breast height (dbh) of 0.4 to 4.9 in. (1 to $12 \mathrm{~cm}$ ) and a height exceeding $20 \mathrm{ft}(6.1 \mathrm{~m})$. Trees are defined as having a dbh of greater than or equal to $5.0 \mathrm{in} .(12.7 \mathrm{~cm})$ and a height exceeding $20 \mathrm{ft}(6.1 \mathrm{~m})$.

\subsection{Data Analysis}

Analyses of vegetative data collected from sampling plots for all 17 sites studied as part of the GRI Wetland Corridors Program were consistent. Analyses focused on comparing the plant communities on the ROW with those in the NAs and determining hydrophytic characteristics of the plant communities in each area. Particular attention was given to dominant species because they are used in several wetland delineation methods. Although the number of species dominant, species richness, and the variety of plant life-forms present are all aspects of community diversity, no diversity indices were calculated. Diversity indices that use coverage values as measures of species importance were considered, but they were judged inappropriate because of differences in the number of strata in the ROW and NAs for the sites included in the Wetland Corridors Program and because coverage values are not additive across strata.

Species Richness, Wetland Indicator Categories, and Species Characteristics. The total number of species present (species richness) was determined for each side of the ROW, for the total ROW, for each NA, and for the NAs combined. Wetland indicator categories (Reed 1988) were identified for each species in the study plots. These categories are defined in Appendix B, Section B.1. The number of species in each category was determined for each area by stratum and for all strata combined. Because one plant species could occur in any or all strata, when data from different strata were combined, each species was considered only once, independent of the number of strata in which it occurred. Species characteristics, including lifeforms and origins, were also determined from Reed (1988). Symbols for life-forms and species origins are given in Appendix B, Section B.2.

Dominant Species. The definition of and methodology for the determination of dominant species in this study were taken from the 1989 Federal Manual (FICWD 1989). In the manual, dominance refers "strictly to the spatial extent of a species that is directly discernible or measurable in the field," as opposed to number of individuals present. Using this definition, dominant species were identified by plant stratum, rather than by total community. For each area, 
the dominant species were determined for each stratum by ranking each species in a plant stratum in descending order relative to total areal coverage of all plants in that stratum. The highest ranking species, which make up 50\% of the total areal coverage or half of the total relative percent coverage (RPC), are the dominant species for that stratum. Any remaining species with $20 \%$ or more RPC are also considered dominant.

Community Similarity Indices. Sørensen's coefficient of community index $\left(\mathrm{CC}_{\mathrm{s}}\right)$ was used to measure similarity between vegetative communities (Brower, Zar, and von Ende 1990). This index uses the following formula:

$$
\mathrm{CC}_{\mathrm{s}}=2 \mathrm{c} /(\mathrm{a}+\mathrm{b})
$$

where

$$
\begin{aligned}
& a=\text { the number of species in community } A, \\
& b=\text { the number of species in community } B, \text { and } \\
& c=\text { the number of species in common between communities A and B. }
\end{aligned}
$$

A $\mathrm{CC}_{\mathrm{s}}$ value of 1.00 indicates $100 \%$ similarity in species composition between communities A and B. A value of 0.00 represents no species in common. Community similarity indices that use coverage values as measures of species importance were considered, but they were judged inappropriate because of differences in the strata present in the plant communities on the ROW compared to those in the NAs and because of the nonadditive characteristic of coverage data.

Comparisons were made between the combined ROWs and combined NAs, the two portions of the ROW, each portion of the ROW and its adjacent NA, and the two NAs.

Prevalence Index Values. Prevalence index values (PIVs) were calculated according to methods outlined in the 1989 Federal Manual (FICWD 1989), substituting RPC data from quadrat coverage estimates for relative frequencies from intercept data. This substitution is logical because both relative frequency and RPC are estimates of relative coverage (Bonham 1989). The PIV is an average wetland indicator value ranging from 1.0 to 5.0 and weighted by the RPC. Because areal coverage was determined by stratum, the PIVs were calculated for each area by stratum only. The average RPCs for each species in the five plots in each area were used in calculating the PIV for the area. The equation for calculating a PIV is presented in Appendix B, Section B.3.

Average Wetland Values. Average wetland values (AWVs) (Zimmerman et al. 1991) were calculated for the species in each of the five areas. This index is an average of the wetland indicator values for all plants present. It differs from the PIV in that it is not weighted by RPC; rather, all plants present are represented equally, regardless of their frequency of occurrence. 
Because areal coverage is not considered, the calculation of an index value is not restricted to one vegetative stratum. An overall site AWV was determined, as well as values for each stratum. See Appendix B, Section B.4, for the equation. 


\section{Results}

Three wetland vegetational communities were sampled along the route of the newly installed 1991 pipeline. These included a scrub-shrub community, an emergent marsh, and a forested wetland. The emergent marsh and the scrub-shrub community were relatively uniform for a sufficient distance along the ROW to permit extensive sampling. The route of the new pipeline enters the wetland just east of Holcomb Street and passes south through an emergent cattail marsh until it enters the scrub-shrub community just north of where the new ROW for the 1991 pipeline joins the ROW for the 1966 pipeline.

Two primary sampling sites were established: one in the emergent marsh along the 1991 pipeline ROW and one in the scrub-shrub community along the 1966/1991 pipeline ROW. A secondary site was established (along the 1966/1991 pipeline ROW) in the forested wetland just east of the scrub-shrub community. (Figure 2 shows the location of each of these sampling sites.) All sites were sampled between July 7 and July 10, 1992.

Vascular plants belonging to 127 different taxa were collected from the three study sites. Of these, 119 were identified to species. The eight plants not identified to species were immature at the time of sampling. (Site-specific lists of species are presented in Appendix C, Tables C.1, C.4, and C.7.)

\subsection{Scrub-Shrub Community}

\subsubsection{General Ecology}

The scrub-shrub community (Figure 2) occupies a nearly level area, with shallow standing water throughout the site. The standing water was maintained at a depth of $10-25$ in. $(25-60 \mathrm{~cm})$ in the sampling area by an extensive, $U$-shaped beaver dam that surrounded the site on the south, east, and west sides. Some standing water was also present on the low side of the dam about $40 \mathrm{~m}$ south of the center of the ROW. This dam was present at the time of the 1991 sampling and had been rebuilt where it was breached by pipeline installation during June 1991. In July 1992, slash used to support construction equipment remained on the working (south) side of the ROW one year after construction. In most places, this slash had been pressed into the saturated soil, presumably by heavy construction equipment. However, toward the south edge of the ROW, some of the ends of the slash and associated soil were near or above the water surface. The rest of the ROW surface was relatively level.

Soil profiles throughout this site were consistent with Lamson soils, as described earlier (Section 2.2). Ninety-seven percent of the ground surface was covered by standing water. Estimates of the standing water for each plot are given in Appendix C, Table C.2. 


\subsubsection{Plant Community}

North of the ROW, the vegetation consisted predominantly of shrubs, with scattered saplings and young trees. The vegetation south of the ROW consisted mainly of saplings and young trees. A number of large willows were present near the beaver dam, close to the southern ends of the transects. Some of these were lodged to the north within the transects. These lodged willows contributed to the diversity of the vegetation in the area because their tilted root masses contained soils exposed above the standing water, providing habitats for a number of more mesic species. A number of young maples had lodged in this area following the 1991 construction activities. Very little emergent herbaceous vegetation was present. The floating lesser duckweed (Lemna minor) covered most of the water surface while the submerged star duckweed (Lemna trisulca) was abundant below the water surface in areas of sufficient direct sunlight.

Plant Species, Life-Forms, and Species Origins. Fifty-five taxa were observed at this site (see Appendix C, Table C.1); 51 of these were identified to species. Their wetland indicator categories, life-forms and origins, and whether they are native to the area, were determined using the National List of Plant Species that Occur in Wetlands, Region 1 (Reed 1988). Eight of the species are listed as regionally introduced species; seven of these are forbs and one a tree. Six of the seven introduced forbs were limited in distribution to the exposed soil entrapped in the roots of the lodged large willow trees. Coverage values for each species in each plot are given in Appendix C, Table C.2. (See Appendix B, Section B.2, for a description of symbols used for describing life-forms and origins.) The distribution by area, along with average percent coverage and absolute frequency, is given for each species in each stratum in Appendix C, Table C.3.

Species Richness and Wetland Indicator Categories. Table 1 lists the number of plant species found in the combined NAs and combined sides of the ROW at the scrub-shrub site. Species counts are given by wetland indicator categories for each vegetative stratum and for all strata combined. Definitions of the strata are provided in Section 3.3, "Sampling Procedures."

Table 1 gives the total number of species found in the NAs and the ROW (columns 3 and 4), the number of species found in both habitats (column 5), and the number of species that occurred in one habitat but not the other (columns 6 and 7). Of the 55 taxa of vascular plants occurring in the transects at the scrub-shrub site, $87 \%$ were present in the combined NAs, while only $45 \%$ were present on the ROW. Most of the $55 \%$ unique to the NAs were unique to the SNA and occurred on the exposed soil associated with the lodged willows.

Thirty-eight percent of all the species in the herb stratum were obligate wetland (OBL) and $23 \%$ were facultative wetland (FACW) species. In other strata, more than $50 \%$ of the species were FACW species. Although the herb stratum was sparse, it contained the greatest number of species and the most OBL species. It also had the greatest number of facultative upland (FACU) species (11) and the only upland (UPL) species present on the site. Nine of the FACU and the single UPL species occurred on the exposed soil associated with the lodged willows in the SNA. Two FACU 
TABLE 1 Number of Plant Species by Wetland Indicator Category Found in the Study Plots in the NAs and the ROW (by individual stratum and combined strata) - ScrubShrub Community

\begin{tabular}{|c|c|c|c|c|c|c|c|}
\hline \multirow[b]{2}{*}{ Stratum } & \multirow{2}{*}{$\begin{array}{l}\text { Wetland } \\
\text { Indicator } \\
\text { Category }\end{array}$} & \multicolumn{6}{|c|}{ Number of Species } \\
\hline & & $\begin{array}{l}\text { Occurring } \\
\text { in NAs }\end{array}$ & $\begin{array}{l}\text { Occurring } \\
\text { in ROW }\end{array}$ & $\begin{array}{l}\text { Common to } \\
\text { Both Areas }\end{array}$ & $\begin{array}{l}\text { Unique } \\
\text { to NAs }\end{array}$ & $\begin{array}{l}\text { Unique } \\
\text { to ROW }\end{array}$ & Total \\
\hline Herb & $\begin{array}{l}\text { OBL } \\
\text { FACW } \\
\text { FAC } \\
\text { FACU } \\
\text { UPL } \\
\text { Unid } \\
\text { TOTAL }^{\text {TOTAL }}\end{array}$ & $\begin{array}{r}16 \\
12 \\
3 \\
9 \\
1 \\
4 \\
45\end{array}$ & $\begin{array}{r}12 \\
6 \\
2 \\
2 \\
0 \\
2 \\
24\end{array}$ & $\begin{array}{r}8 \\
6 \\
1 \\
0 \\
0 \\
2 \\
17\end{array}$ & $\begin{array}{r}8 \\
6 \\
2 \\
9 \\
1 \\
2 \\
28\end{array}$ & $\begin{array}{l}4 \\
0 \\
1 \\
2 \\
0 \\
0 \\
7\end{array}$ & $\begin{array}{r}20 \\
12 \\
4 \\
11 \\
1 \\
4 \\
52\end{array}$ \\
\hline Shrub & $\begin{array}{l}\text { OBL } \\
\text { FACW } \\
\text { FAC } \\
\text { FACU } \\
\text { UPL } \\
\text { Unid } \\
\text { TOTAL }\end{array}$ & $\begin{array}{l}1 \\
6 \\
2 \\
0 \\
0 \\
0 \\
9\end{array}$ & $\begin{array}{l}1 \\
2 \\
0 \\
0 \\
0 \\
0 \\
3\end{array}$ & $\begin{array}{l}1 \\
2 \\
0 \\
0 \\
0 \\
0 \\
3\end{array}$ & $\begin{array}{l}0 \\
4 \\
2 \\
0 \\
0 \\
0 \\
6\end{array}$ & $\begin{array}{l}0 \\
0 \\
0 \\
0 \\
0 \\
0 \\
0\end{array}$ & $\begin{array}{l}1 \\
6 \\
2 \\
0 \\
0 \\
0 \\
9\end{array}$ \\
\hline Sapling & $\begin{array}{l}\text { OBL } \\
\text { FACW } \\
\text { FAC } \\
\text { FACU } \\
\text { UPL } \\
\text { Unid } \\
\text { TOTAL }\end{array}$ & $\begin{array}{l}0 \\
2 \\
1 \\
0 \\
0 \\
0 \\
3\end{array}$ & $\begin{array}{l}0 \\
0 \\
0 \\
0 \\
0 \\
0 \\
0\end{array}$ & $\begin{array}{l}0 \\
0 \\
0 \\
0 \\
0 \\
0 \\
0\end{array}$ & $\begin{array}{l}0 \\
2 \\
1 \\
0 \\
0 \\
0 \\
3\end{array}$ & $\begin{array}{l}0 \\
0 \\
0 \\
0 \\
0 \\
0 \\
0\end{array}$ & $\begin{array}{l}0 \\
2 \\
1 \\
0 \\
0 \\
0 \\
3\end{array}$ \\
\hline Tree & $\begin{array}{l}\text { OBL } \\
\text { FACW } \\
\text { FAC } \\
\text { FACU } \\
\text { UPL } \\
\text { Unid } \\
\text { TOTAL }\end{array}$ & $\begin{array}{l}0 \\
2 \\
1 \\
0 \\
0 \\
0 \\
3\end{array}$ & $\begin{array}{l}0 \\
0 \\
0 \\
0 \\
0 \\
0 \\
0\end{array}$ & $\begin{array}{l}0 \\
0 \\
0 \\
0 \\
0 \\
0 \\
0\end{array}$ & $\begin{array}{l}0 \\
2 \\
1 \\
0 \\
0 \\
0 \\
3\end{array}$ & $\begin{array}{l}0 \\
0 \\
0 \\
0 \\
0 \\
0 \\
0\end{array}$ & $\begin{array}{l}0 \\
2 \\
1 \\
0 \\
0 \\
0 \\
3\end{array}$ \\
\hline $\begin{array}{l}\text { Combined } \\
\text { Strata }^{c}\end{array}$ & $\begin{array}{l}\text { OBL } \\
\text { FACW } \\
\text { FAC } \\
\text { FACU } \\
\text { UPL } \\
\text { Unid } \\
\text { TOTAL }\end{array}$ & $\begin{array}{r}16 \\
14 \\
4 \\
9 \\
1 \\
4 \\
48\end{array}$ & $\begin{array}{r}13 \\
6 \\
2 \\
2 \\
0 \\
2 \\
25\end{array}$ & $\begin{array}{r}9 \\
6 \\
1 \\
0 \\
0 \\
2 \\
18\end{array}$ & $\begin{array}{r}7 \\
8 \\
3 \\
9 \\
1 \\
2 \\
30\end{array}$ & $\begin{array}{l}4 \\
0 \\
1 \\
2 \\
0 \\
0 \\
7\end{array}$ & $\begin{array}{r}20 \\
14 \\
5 \\
11 \\
1 \\
4 \\
55\end{array}$ \\
\hline
\end{tabular}

a $\mathrm{OBL}=$ obligate wetland species; $F A C W=$ facultative wetland species; $F A C=$ facultative species; FACU = facultative upland species; and UPL = upland species. See Appendix B for more detailed information on wetland indicator categories.

b Plants not identified to species or not assigned a wetland indicator category according to Reed (1988).

c When data from different strata are combined, each species is considered only once. 
species were present in the ROW only. Four taxa in the herb stratum could not be identified to species and therefore could not be classified. No OBL species were found in either the sapling or the tree stratum.

Table 2 summarizes the distribution of plants in the plots on the south and north sides of the ROW at the scrub-shrub site. Of the 25 species found in the ROW, $52 \%$ occurred in both the north and south sides, $40 \%$ in the south side only, and $8 \%$ in the north side only. The 10 species unique to the south side of the ROW occurred mostly in areas where the soil surface was elevated by embedded slash. Shrub-sized specimens were found only near the northern edge of the ROW, which was the storage side during pipeline construction. These specimens remained because of incomplete clearing of the ROW. No saplings or trees remained in the ROW.

As shown in Table 3, the NAs at the scrub-shrub site contained a total of 48 taxa, with $25 \%$ occurring in both the NNA and SNA. Sixty-three percent were unique to the SNA, and $13 \%$ were unique to the NNA. In the herb stratum, $69 \%$ of the species were unique to the SNA and $11 \%$ were unique to the NNA. The shrub stratum contained nine species, $67 \%$ of which were unique to the NNA with $33 \%$ occurring in both the NNA and SNA. The three species common to both the NNA and SNA were all tree species represented by shrub-size specimens. Two species of saplings, silver maple (Acer saccharinum) and green ash (Fraxinus pennsylvanicum), occurred in both areas, while crack willow (Salix fragilis) was unique to the SNA. In the tree stratum, silver maple and crack willow occurred in both areas, while green ash was unique to the NNA.

Figure 8 shows a graphic presentation of the number of species by wetland indicator category for each area in the scrub-shrub community. Figure 9 shows the percentage of species by wetland indicator category for each area. The percentages of OBL, FACW, and facultative (FAC) species in the NAs totaled $70.8 \%$, while the percentages of OBL, FACW, and FAC species in the ROW totaled $84.0 \%$. The NNA contained $100 \%$ OBL, FACW, and FAC species, while only $66.7 \%$ of the species in the SNA belong in these categories.

Dominance. The dominant species in each stratum of the scrub-shrub community are listed with the RPC for each in Table 4. The strata in all areas were dominated by OBL or FACW species, except for the tree stratum, which was dominated by one FACW and one FAC species.

The herb stratum in the NAs was dominated by subsurface suspended star duckweed and surface floating lesser duckweed with RPCs of $48.9 \%$ and $43.6 \%$, respectively. The cumulative sum of the absolute average coverage for the two duckweeds was $122 \%$; the sum of the coverage for all emergent rooted vascular plants in the herbaceous stratum was $9.95 \%$. Many of the rooted vascular plants occurred on the exposed soil in the roots of the lodged willows; however, some seedlings of the woody species were emerging from standing water. Blue cattail (Typha $\times$ glauca) was the leading dominant in the ROW; lesser duckweed was the second dominant. RPCs for these two species were $26.8 \%$ and $25.5 \%$, respectively. Total absolute coverage for the ROW was $90.9 \%$ with a $50.5 \%$ coverage of emergent vegetation. 
TABLE 2 Number of Plant Species by Wetland Indicator Category Found in the Study Plots in the North and South Sides of the ROW (by individual stratum and combined strata) Scrub-Shrub Community

\begin{tabular}{|c|c|c|c|c|c|c|c|}
\hline \multirow[b]{2}{*}{ Stratum } & \multirow[b]{2}{*}{$\begin{array}{l}\text { Wetland } \\
\text { Indicator } \\
\text { Category }\end{array}$} & \multicolumn{6}{|c|}{ Number of Species } \\
\hline & & $\begin{array}{l}\text { Occurring } \\
\text { in North } \\
\text { Side of } \\
\text { ROW }\end{array}$ & $\begin{array}{l}\text { Occurring } \\
\text { in South } \\
\text { Side of } \\
\text { ROW }\end{array}$ & $\begin{array}{c}\text { Common to } \\
\text { Both Sides } \\
\text { of ROW }\end{array}$ & $\begin{array}{l}\text { Unique } \\
\text { to North } \\
\text { Side of } \\
\text { Row }\end{array}$ & $\begin{array}{l}\text { Unique } \\
\text { to South } \\
\text { Side of } \\
\text { ROW }\end{array}$ & Total \\
\hline \multirow[t]{7}{*}{ Herb } & OBL & 10 & 11 & 9 & 1 & 2 & 12 \\
\hline & FACW & 1 & 6 & 1 & 0 & 5 & 6 \\
\hline & FAC & 0 & 2 & 0 & 0 & 2 & 2 \\
\hline & FACU & 1 & 2 & 1 & 0 & 1 & 2 \\
\hline & UPL & 0 & 0 & 0 & 0 & 0 & 0 \\
\hline & Unida & 1 & 2 & 1 & 0 & 1 & 2 \\
\hline & TOTAL & 13 & 23 & 12 & 1 & 11 & 24 \\
\hline \multirow[t]{7}{*}{ Shrub } & OBL & 1 & 0 & 0 & 1 & 0 & 1. \\
\hline & FACW & 2 & 0 & 0 & 2 & 0 & 2 \\
\hline & FAC & 0 & 0 & 0 & 0 & 0 & 0 \\
\hline & FACU & 0 & 0 & 0 & 0 & 0 & 0 \\
\hline & UPL & 0 & 0 & 0 & 0 & 0 & 0 \\
\hline & Unid & 0 & 0 & 0 & 0 & 0 & 0 \\
\hline & TOTAL & 3 & 0 & 0 & 3 & 0 & 3 \\
\hline Combined & $\mathrm{OBL}$ & 11 & 11 & 9 & 2 & 2 & 13 \\
\hline \multirow[t]{6}{*}{ Strata } & FACW & 2 & 6 & 2 & 0 & 4 & 6 \\
\hline & FAC & 0 & 2 & 0 & 0 & 2 & 2 \\
\hline & FACU & 1 & 2 & 1 & 0 & 1 & 2 \\
\hline & UPL & 0 & 0 & 0 & 0 & 0 & 0 \\
\hline & Unid & 1 & 2 & 1 & 0 & 1 & 2 \\
\hline & TOTAL & 15 & 23 & 13 & 2 & 10 & 25 \\
\hline
\end{tabular}

a Plants not identified to species or not assigned a wetland indicator category according to Reed (1988). 
TABLE 3 Number of Plant Species by Wetland Indicator Category Found in the Study Plots in the NNA and SNA (by individual stratum and combined strata) - Scrub-Shrub Community

\begin{tabular}{|c|c|c|c|c|c|c|c|}
\hline \multirow[b]{2}{*}{ Stratum } & \multirow{2}{*}{$\begin{array}{l}\text { Wetland } \\
\text { Indicator } \\
\text { Category }\end{array}$} & \multicolumn{6}{|c|}{ Number of Species } \\
\hline & & $\begin{array}{l}\text { Occurring } \\
\text { in NNA }\end{array}$ & $\begin{array}{l}\text { Occurring } \\
\text { in SNA }\end{array}$ & $\begin{array}{l}\text { Common to } \\
\text { Both Areas }\end{array}$ & $\begin{array}{l}\text { Unique } \\
\text { to NNA }\end{array}$ & $\begin{array}{l}\text { Unique } \\
\text { to SNA }\end{array}$ & Total \\
\hline \multirow[t]{7}{*}{ Herb } & OBL & 8 & 14 & 6 & 2 & 8 & 16 \\
\hline & FACW & 4 & 10 & 2 & 2 & 8 & 12 \\
\hline & FAC & 1 & 2 & $\overline{0}$ & 1 & 2 & 3 \\
\hline & FACU & 0 & 9 & 0 & 0 & 9 & 9 \\
\hline & UPL & 0 & 1 & 0 & 0 & 1 & 1 \\
\hline & Unid ${ }^{a}$ & 1 & 4 & 1 & 0 & 3 & 4 \\
\hline & TOTAL & 14 & 40 & 9 & 5 & 31 & 45 \\
\hline \multirow[t]{7}{*}{ Shrub } & OBL & 1 & 0 & 0 & 1 & 0 & 1 \\
\hline & FACW & 6 & 3 & 3 & 3 & 0 & 6 \\
\hline & FAC & 2 & 0 & 0 & 2 & 0 & 2 \\
\hline & FACU & 0 & 0 & 0 & $\overline{0}$ & 0 & 0 \\
\hline & UPL & 0 & 0 & 0 & 0 & 0 & 0 \\
\hline & Unid & 0 & 0 & 0 & 0 & 0 & 0 \\
\hline & TOTAL & 9 & 3 & 3 & 6 & 0 & 9 \\
\hline \multirow[t]{7}{*}{ Sapling } & OBL & 0 & 0 & 0 & 0 & 0 & 0 \\
\hline & FACW & 2 & 2 & 2 & 0 & 0 & 2 \\
\hline & FAC & 0 & 1 & 0 & 0 & 1 & 1 \\
\hline & FACU & 0 & 0 & 0 & 0 & 0 & 0 \\
\hline & UPL & 0 & 0 & 0 & 0 & 0 & 0 \\
\hline & Unid & 0 & 0 & 0 & 0 & 0 & 0 \\
\hline & TOTAL & 2 & 3 & 2 & 0 & 1 & 3 \\
\hline \multirow[t]{7}{*}{ Tree } & OBL & 0 & 0 & 0 & 0 & 0 & 0 \\
\hline & FACW & 2 & 1 & 1 & 1 & 0 & 2 \\
\hline & FAC & 1 & 1 & 1 & 0 & 0 & 1 \\
\hline & FACU & 0 & 0 & 0 & 0 & 0 & 0 \\
\hline & UPL & 0 & 0 & 0 & 0 & 0 & 0 \\
\hline & Unid & 0 & 0 & 0 & 0 & 0 & 0 \\
\hline & TOTAL & 3 & 2 & 2 & 1 & 0 & 3 \\
\hline Combined & OBL & 8 & 14 & 6 & 2 & 8 & 16 \\
\hline \multirow[t]{6}{*}{ Stratab } & FACW & 6 & 11 & 3 & 3 & 8 & 14 \\
\hline & FAC & 3 & 3 & 2 & 1 & 1 & 4 \\
\hline & FACU & 0 & 9 & 0 & 0 & 9 & 9 \\
\hline & UPL & 0 & 1 & 0 & 0 & 1 & 1 \\
\hline & Unid & 1 & 4 & 1 & 0 & 3 & 4 \\
\hline & TOTAL & 18 & 42 & 12 & 6 & 30 & 48 \\
\hline
\end{tabular}

a Plants not identified to species or not assigned a wetland indicator category according to Reed (1988).

b When data from different strata are combined, each species is counted only once. 


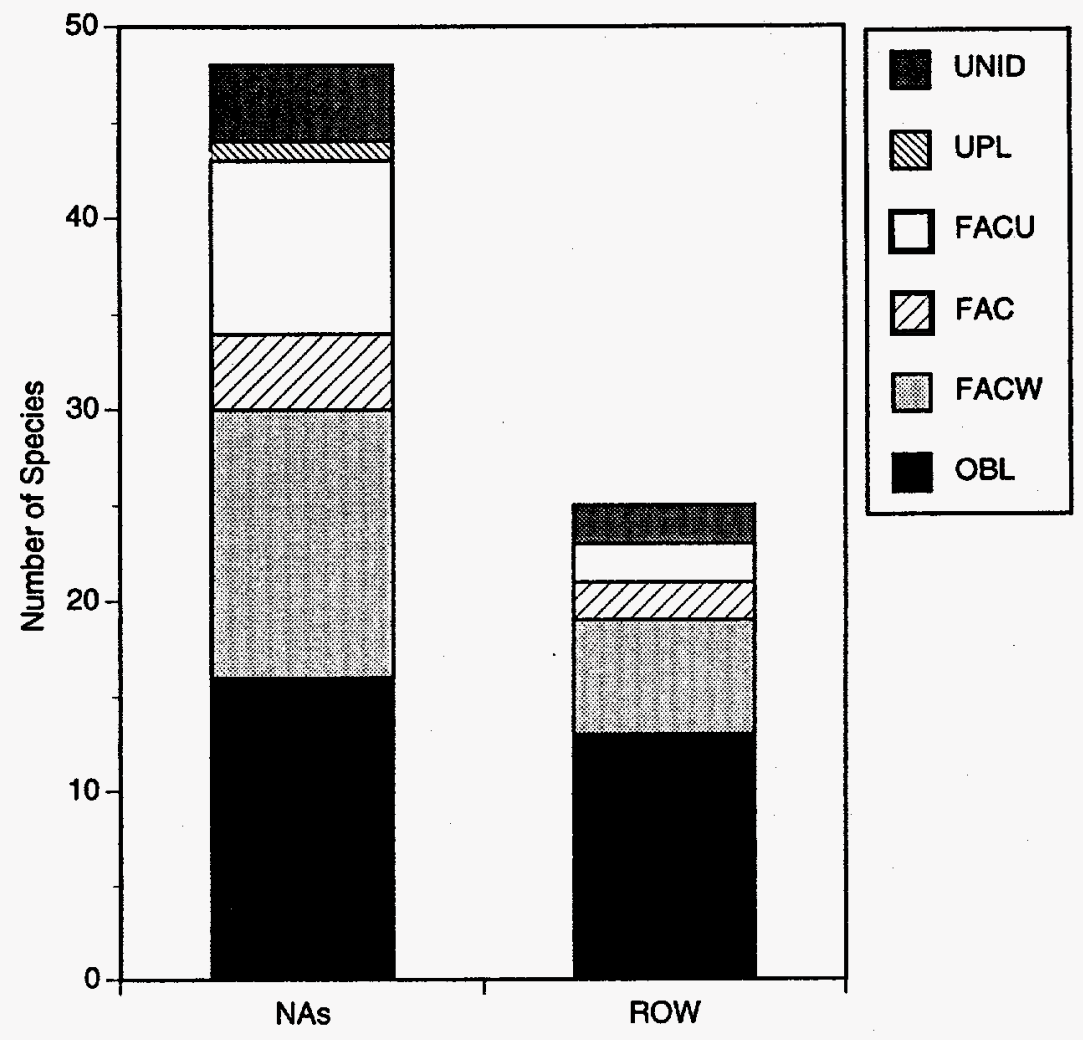

FIGURE 8 Number of Plant Species in Each Wetland Indicator Category by Area in the Scrub-Shrub Community

The dominant species in the shrub stratum in the NAs were meadow willow (Salix petiolaris), an OBL species, and pussy willow (Salix discolor), a FACW species (see Table 4 for RPCs). The sum of the absolute coverages for individual species in the shrub stratum in the NAs was $22.5 \%$. The sum of absolute coverages of individual species in the shrub stratum in the ROW was $1.1 \%$. Only three species were present in the shrub stratum in the ROW: two tree species and one shrub species. The two tree species were dominant, as listed in Table 4.

A sapling stratum, present only in the NAs, was dominated by silver maple, which accounted for $80.1 \%$ of the RPC. Green ash and crack willow were also present.

The tree stratum, also present only in the NAs, was dominated by crack willow and silver maple, which together accounted for $98.9 \%$ of the RPC.

Coefficient of Community. Table 5 lists Sørensen's coefficient of community $\left(\mathrm{CC}_{\mathrm{s}}\right)$ values, derived by comparing species present in the various areas. When the strata are combined and when only herb stratum species are considered, the $\mathrm{CC}_{\mathrm{S}}$ obtained by comparing species on the two sides of the ROW was higher than the $\mathrm{CC}_{s}$ obtained by comparing the two NAs. The low similarity for the herb stratum in the two NAs is related to the presence of unique species 


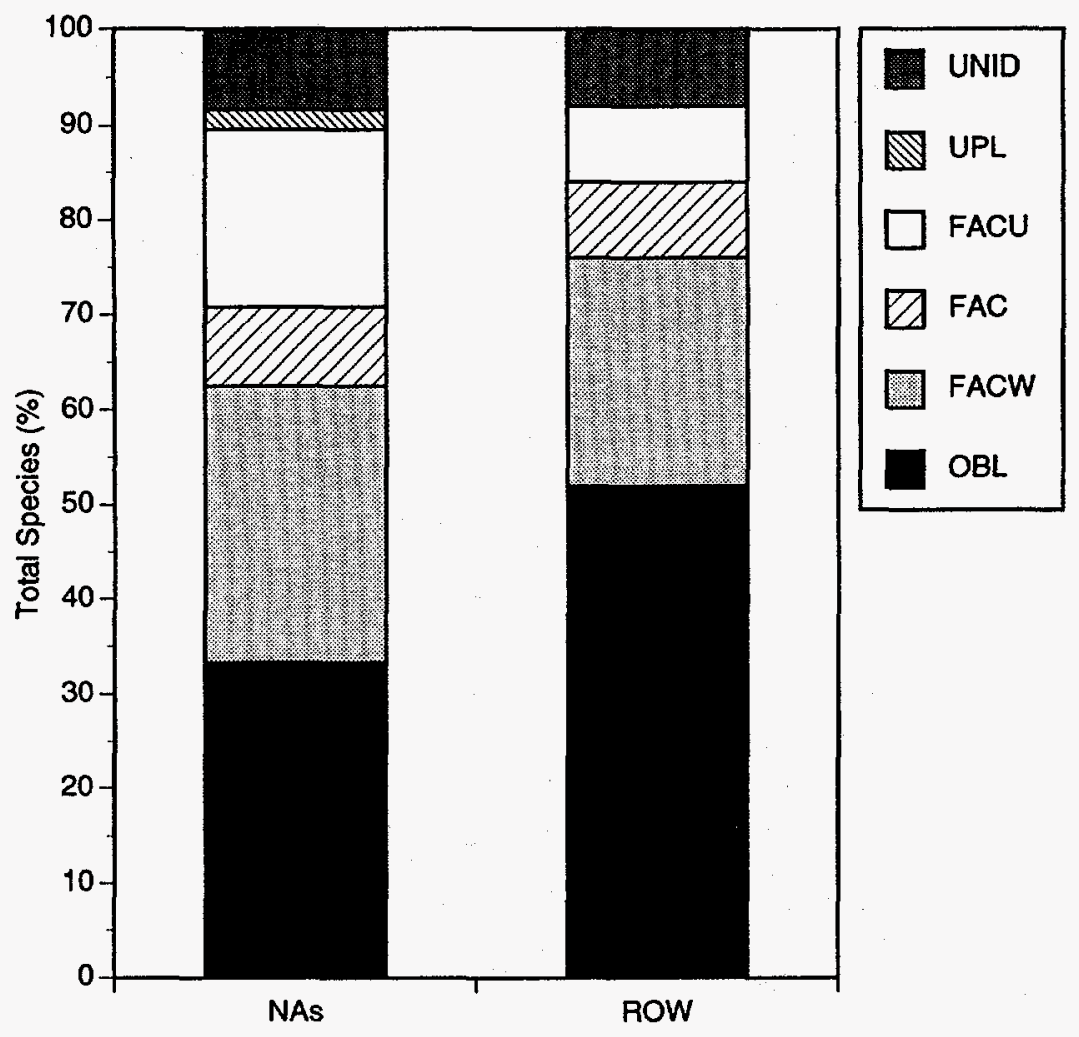

FIGURE 9 Percentage of Species in Each Wetland Indicator Category by Area in the Scrub-Shrub Community

associated with the exposed soil of the lodged willows in the SNA only. The shrub strata in the two NAs had a $\mathrm{CC}_{\mathrm{s}}$ of 0.50 ; the sapling and tree strata both had a $\mathrm{CC}_{\mathrm{s}}$ of 0.80 . Shrubs were present only on the north side of the ROW.

Prevalence Index Values and Average Wetland Values. Table 6 presents, by stratum, the PIVs and AWVs for the combined ROW and the combined NAs for all species and for dominants only. The PIVs and AWVs for all species and for dominants only in the herb, shrub, and sapling strata were less than 3.00, indicating wetland vegetation. Both the PIV and the AWV for all tree stratum species in the NAs were less than 3.00; the PIV and the AWV for dominant tree stratum species only were 3.00 .

The large difference between the AWV for the NAs and the AWV for the ROW, when all species in the herb stratum were considered, was related to the more mesic conditions of the exposed soil in the roots of the lodged willows. The low wetland indicator values for the dominants in the herb stratum in both areas were due to the abundance of the duckweeds and cattails, which are OBL species. The dominants in the shrub stratum in the NAs also had lower wetland indicator values than did all species combined. The values for the shrub stratum on the ROW probably have little meaning because the few shrubs present on the ROW are a result of incomplete destruction of the ROW vegetation during pipeline construction, rather than a result of habitat differences. 
TABLE 4 Dominant Species by Vegetative Stratum in Each Habitat - Scrub-Shrub Community

\begin{tabular}{|c|c|c|c|c|c|c|}
\hline Stratum & Areas & $\begin{array}{l}\text { Species } \\
\text { Scientific Name }\end{array}$ & Common Name & $\begin{array}{l}\text { Wetland } \\
\text { Indicator } \\
\text { Category }\end{array}$ & $\begin{array}{l}\text { Relative } \\
\text { Percent } \\
\text { Coverage }\end{array}$ & $\begin{array}{l}\text { Sum of } \\
\text { Relative } \\
\text { Percent } \\
\text { Coverage }\end{array}$ \\
\hline Herb & NAs & $\begin{array}{l}\text { Lemna trisulca } \\
\text { Lemna minor }\end{array}$ & $\begin{array}{l}\text { Star duckweed } \\
\text { Lesser duckweed }\end{array}$ & $\begin{array}{l}\text { OBL } \\
\text { OBL }\end{array}$ & $\begin{array}{l}48.9 \\
43.6\end{array}$ & 92.5 \\
\hline & ROW & $\begin{array}{l}\text { Typha } \times \text { glauca } \\
\text { Lemna minor }\end{array}$ & $\begin{array}{l}\text { Blue cattail } \\
\text { Lesser duckweed }\end{array}$ & $\begin{array}{l}\mathrm{OBL} \\
\mathrm{OBL}\end{array}$ & $\begin{array}{l}26.8 \\
25.5\end{array}$ & 52.3 \\
\hline Shrub & NAs & $\begin{array}{l}\text { Salix petiolaris } \\
\text { Salix discolor }\end{array}$ & $\begin{array}{l}\text { Meadow willow } \\
\text { Pussy willow }\end{array}$ & $\begin{array}{l}\text { OBL } \\
\text { FACW }\end{array}$ & $\begin{array}{l}44.5 \\
14.7\end{array}$ & 59.2 \\
\hline & ROW & $\begin{array}{l}\text { Acer saccharinum } \\
\text { Fraxinus pennsylvanica }\end{array}$ & $\begin{array}{l}\text { Silver maple } \\
\text { Green ash }\end{array}$ & $\begin{array}{l}\text { FACW } \\
\text { FACW }\end{array}$ & $\begin{array}{l}45.5 \\
36.4\end{array}$ & 81.9 \\
\hline Sapling & NAs & Acer saccharinum & Silver maple & FACW & 80.1 & 80.1 \\
\hline Tree & NAs & $\begin{array}{l}\text { Salix fragilis } \\
\text { Acer saccharinum }\end{array}$ & $\begin{array}{l}\text { Crack willow } \\
\text { Silver maple }\end{array}$ & $\begin{array}{l}\text { FAC } \\
\text { FACW }\end{array}$ & $\begin{array}{l}70.2 \\
28.7\end{array}$ & 98.9 \\
\hline
\end{tabular}

TABLE 5 Coefficient of Community Values Comparing Areas on the Basis of Species Composition - Scrub-Shrub Community

\begin{tabular}{lccc} 
& \multicolumn{3}{c}{ Comparison } \\
\cline { 2 - 4 } Stratum & NAs to ROW & $\begin{array}{c}\text { North ROW to } \\
\text { South ROW }\end{array}$ & NNA to SNA \\
\hline Herb & 0.49 & 0.67 & 0.33 \\
Shrub & 0.50 & 0.00 & 0.50 \\
Sapling & 0.00 & NCa & 0.80 \\
Tree & 0.00 & NC & 0.80 \\
Combined & 0.49 & 0.68 & 0.40 \\
\hline
\end{tabular}

a $\mathrm{NC}=$ not calculated. No species were present in this stratum. 
TABLE 6 Prevalence Index and Average Wetland Values for All Species and Dominant Species Only in the NAs and the ROW (by individual stratum and combined strata) - Scrub-Shrub Community

\begin{tabular}{|c|c|c|c|c|}
\hline Stratum & Areas & Species: & $\begin{array}{l}\text { Prevalence } \\
\text { Index Value }\end{array}$ & $\begin{array}{c}\text { Average } \\
\text { Wetland Value }\end{array}$ \\
\hline \multirow[t]{4}{*}{ Herb } & NAs & All & 1.05 & 2.20 \\
\hline & & Dominant only & 1.00 & 1.00 \\
\hline & Row & All & 1.02 & 1.73 \\
\hline & & Dominant only & 1.00 & 1.00 \\
\hline \multirow[t]{4}{*}{ Shrub } & NAS & All: & 1.67 & 2.11 \\
\hline & & Dominant only & 1.25 & 1.50 \\
\hline & ROW & All: & 1.82 & 1.67 \\
\hline & & Dominant only & 2.00 & 2.00 \\
\hline \multirow[t]{2}{*}{ Sapling } & NAS & All & 2.05 & 2.33 \\
\hline & & Dominant only & 2.00 & 2.00 \\
\hline \multirow[t]{2}{*}{ Tree } & NAs: & All & 2.71 & 2.33 \\
\hline & & Dominant only & 3.00 & 3.00 \\
\hline \multirow{2}{*}{$\begin{array}{l}\text { Combined } \\
\text { Strata }\end{array}$} & NAs: & All & $N C^{a}$ & 2.20 \\
\hline & ROW & All & NC & 1.70 \\
\hline
\end{tabular}

a $\mathrm{NC}=$ not calculated. Values could not be calculated for combined strata because areal cover (which is not additive) is used in its calculation.

The tree stratum had the highest PIVs and AWVs for all species and for dominants only. The value of 3.00 for dominant tree stratum species indicated neither wetland nor upland vegetation.

\subsubsection{Comparison of Data from 1991 and 1992}

Sampling was performed in June 1991, just before pipeline construction, and again in July 1992, after the 1991 pipeline had been in place for a year. Water levels in the scrub-shrub community in 1992 were similar to those that occurred just prior to pipeline construction in 1991. (All references to 1991 data in this section refer to Van Dyke et al. 1994.) Visual inspection indicted that the beaver dam responsible for maintaining the water levels had been repaired at the two sites where it had been breached during pipeline construction. In 1992, the ROW surface lacked the depressions that had been present in 1991. Instead, the southern side was elevated by 
partially buried slash, with some of the ends of the woody slash exposed above the water near the southern edge of the ROW.

Shrubs, saplings, and trees had been almost entirely removed from the ROW by construction of the 1991 pipeline, except for the few remaining shrubs occurring near the northern edge. Emergent herb stratum vegetation on the ROW covered 50.5\% of the surface area in 1992, compared to 5.6\% in 1991. Two species of duckweed were abundant in 1992: lesser duckweed, a surface floating species, and star duckweed, a submerged suspended species. These contributed $40.4 \%$ of the total herb stratum in 1992 , compared with $99 \%$ coverage for the floating lesser duckweed in 1991. Star duckweed was not recorded in 1991.

Pussy willow and meadow willow were both dominant in the shrub stratum in both years. Silver maple qualified as a dominant shrub in 1991, but not in 1992. The sapling stratum was dominated by silver maple both years. Silver maple and crack willow dominated the tree stratum both years. Estimates of percent coverage for dominant species varied considerably between years, and the rankings of the dominants also changed.

The numbers of shrub, sapling, and tree species encountered in sampling plots in the NAs were slightly higher in 1991, compared to 1992 . However, the number of herb species encountered in NA sampling plots in 1992 (45) was more than double the number encountered in 1991 (20). In both years, total coverage by emergent herbs was low, with an average cover of 9.95\% in 1992 and $4.15 \%$ in 1991 . Most of the herbs in the NAs, other than the duckweeds, occurred on exposed soil associated with the lodged willows.

Table 7 presents a comparison of the numbers of plants present in sampling plots in the ROW and the NAs (scrub-shrub community) in 1991 and 1992. Individual species present only in 1991, present only in 1992, and present in both years are listed in Appendix D, Tables D.1, D.2, and D.3, respectively. Sixteen species were present in the plots during both years; eleven of these were shrub or tree species. Seven species, all shrubs or trees occurring in the NAs, were encountered in 1991 but not in 1992. Fifteen percent of the 39 species that were encountered in 1992 but not in 1991 were found only in the ROW, while $62 \%$ were found only in the NAs; $23 \%$ occurred in both. Although the ROW had been severely disturbed, 15 of the 18 species present in 1991 were again present in 1992, along with 15 new species, resulting in an $83 \%$ increase in the number of species in the ROW.

Table 8 provides a comparison of plant species collected in 1991 to those collected in 1992 using Sørensen's $\mathrm{CC}_{\mathrm{s}}$ values. The shrub and sapling strata in the NAs showed the greatest similarity. Comparison of the species composition of the herb stratum in the ROW in 1991 and 1992 and the herb stratum in the NAs in 1991 and 1992 resulted in low $\mathrm{CC}_{\mathrm{S}}$ values.

Table 9 compares AWVs and PIVs by stratum for all species and for dominants only for 1991 and 1992. Little variation occurred between the two years. 
TABLE 7 Number of Plant Species Present in 1991 Only, 1992 Only, and Both 1991 and 1992 by Wetland Indicator Category - Scrub-Shrub Community

\begin{tabular}{|c|c|c|c|c|c|c|c|c|c|}
\hline \multirow{2}{*}{$\begin{array}{l}\text { Wetland } \\
\text { Indicator } \\
\text { Category }\end{array}$} & \multicolumn{4}{|c|}{ Present in 1991 Only } & \multicolumn{4}{|c|}{ Present in 1992 Only } & \multirow{2}{*}{$\begin{array}{c}\begin{array}{c}\text { Present in } 1991 \\
\text { and } 1992^{b}\end{array} \\
\text { Total }\end{array}$} \\
\hline & ROW & NAs & Both & Total & ROW & NAs & Both & Total & \\
\hline OBL & 0 & 1 & 0 & 1 & 4 & 7 & 5 & 16 & 0 \\
\hline FACW & 0 & 2 & 0 & 2 & 0 & 4 & 2 & 6 & 4 \\
\hline FAC & 0 & 0 & 2 & 2 & 0 & 1 & 0 & 1 & 8 \\
\hline FACU & 0 & 0 & 0 & 0 & 2 & 9 & 0 & 11 & 4 \\
\hline UPL & 0 & 0 & 1 & 1 & 0 & 1 & 0 & 1 & 0 \\
\hline Unida & 0 & 1 & 0 & 1 & 0 & 2 & 2 & 4 & 0 \\
\hline Total & 0 & 4 & 3 & 7 & 6 & 24 & 9 & 39 & 16 \\
\hline
\end{tabular}

a Plants not identified to species or not assigned a wetland indicator category according to Reed (1988).

b Species that were present in both areas in at least one of the two years.

TABLE 8 Coefficient of Community Values

Comparing 1991 and 1992 Data on the

Basis of Species Composition - Scrub-

Shrub Community

\begin{tabular}{|c|c|c|}
\hline \multirow[b]{3}{*}{ Stratum } & \multicolumn{2}{|c|}{ Comparison } \\
\hline & NAs & ROW \\
\hline & 1991 to 1992 & 1991 to 1992 \\
\hline Herb & 0.40 & 0.44 \\
\hline Shrub & 0.86 & 0.40 \\
\hline Sapling & 0.75 & 0.00 \\
\hline Tree & 0.57 & 0.00 \\
\hline Combined & 0.43 & 0.53 \\
\hline
\end{tabular}


TABLE 9 Prevalence Index and Average Wetland Values for All Species and Dominant Species Only in the NAs and the ROW (by individual stratum and combined strata) - Scrub-Shrub Community

\begin{tabular}{|c|c|c|c|c|c|c|}
\hline \multirow[b]{2}{*}{ Stratum } & \multirow[b]{2}{*}{ Areas } & \multirow[b]{2}{*}{ Species } & \multicolumn{2}{|c|}{$\begin{array}{l}\text { Prevalence } \\
\text { Index Value }\end{array}$} & \multicolumn{2}{|c|}{$\begin{array}{c}\text { Average } \\
\text { Wetland Value }\end{array}$} \\
\hline & & & 1991 & 1992 & 1991 & 1992 \\
\hline \multirow[t]{4}{*}{ Herb } & NAs & All & 1.04 & 1.05 & 2.00 & 2.20 \\
\hline & & Dominant only & 1.00 & 1.00 & 1.00 & 1.00 \\
\hline & ROW & All & 1.06 & 1.02 & 2.08 & 1.73 \\
\hline & & Dominant only & 1.00 & 1.00 & 1.00 & 1.00 \\
\hline \multirow[t]{4}{*}{ Shrub } & NAs & All & 1.96 & 1.67 & 2.42 & 2.11 \\
\hline & & Dominant only & 1.79 & 1.25 & 1.67 & 1.50 \\
\hline & ROW & All & 1.86 & 1.82 & 2.42 & 1.67 \\
\hline & & Dominant only & 1.57 & 2.00 & 1.67 & 2.00 \\
\hline \multirow[t]{4}{*}{ Sapling } & NAs & All & 2.00 & 2.05 & 2.20 & 2.33 \\
\hline & & Dominant only & 2.00 & 2.00 & 2.00 & 2.00 \\
\hline & Rowa & All & 2.00 & none & 2.00 & none \\
\hline & & Dominant only & 2.00 & none & 2.00 & none \\
\hline \multirow[t]{4}{*}{ Tree } & NAs & All & 2.38 & 2.71 & 2.50 & 2.33 \\
\hline & & Dominant only & 2.35 & 3.00 & 2.50 & 3.00 \\
\hline & ROWa & All & 2.94 & none & 2.67 & none \\
\hline & & Dominant only & 3.00 & none & 3.00 & none \\
\hline Combined & NAs & All & $N C^{b}$ & NC & 2.20 & 2.20 \\
\hline Strata & ROW & All & NC & NC & 2.27 & 1.83 \\
\hline
\end{tabular}

a No trees or saplings were present on the ROW in 1992.

b $N C=$ not calculated. Values could not be calculated for combined strata because areal cover (which is not additive) is used in its calculation. 


\subsection{Emergent Marsh Community}

\subsubsection{General Ecology}

The emergent marsh is a nearly level area draining toward the south (Figure 2). The soil surface is partially covered by standing water in each transect. The percentage of the surface covered by standing water, averaged across all transects, was $14 \%$ for the NAs and $40 \%$ for the ROW. Less than $1 \%$ of the soil surface was not covered by water or vegetation in the NAs; $6 \%$ of the soil in the one-year-old ROW was exposed.

The soils in this area are mapped as Lamson soils on the Jefferson County soil maps. (A description of Lamson soils is given in Section 2.2.) Observations of hand-augured soil cores taken along each transect confirmed the presence of Lamson soils throughout the study site.

\subsubsection{Plant Community}

The dense vegetation in the NAs consisted predominantly of cattails, horsetails, and a wide variety of forbs and shrubs. The shrubs were most abundant toward the center of the site (transects T2, T3, and T4). Vegetation in the ROW was poorly developed, with only $25 \%$ total vegetative areal coverage.

Plant Species, Life-Forms, and Species Origins. A total of 79 plant taxa were observed in the emergent marsh site; 75 of these were represented in the transects. Wetland indicator values, life-forms, and origins (Reed 1988) for the 70 plants identified to species are given in Appendix C, Table C.4. Fifteen species (two grasses, twelve forbs, and one shrub) were introduced, non-native species. Coverage values for each species in each plot are given in Table C.5. Sixty-two of the species occurred in plots in the NAs and 37 in plots within the ROW. Species distributions, average percent coverages (by area), and absolute frequencies are provided in Table C.6. (Appendix B, Section B.2, provides definitions of the symbols used to describe life-forms and origins.)

The herb stratum in the NAs contained 57 taxa, consisting of two ferns, two horsetails, fifteen sedges, seven grasses, two rushes, twenty forbs, five woody species, and four forbs that could not be identified to species. Seven of the eight introduced species were represented in the herb stratum.

The shrub stratum in the NAs contained eight species, including shrub-sized specimens of one tree species. No sapling or tree-size specimens were present. 
The herb stratum in the ROW was composed of 37 species, including one fern, two horsetails, four rushes, two sedges, five grasses, twenty-one forbs, and two woody species. No shrubs or larger plants were present in the ROW.

Species Richness and Wetland Indicator Categories. Table 10 gives the number of species by wetland indicator category for the NAs and the ROW at the emergent marsh site. Of the 75 species present, 24 occurred in both areas, 38 were unique to the NAs, and 13 were unique to the ROW. In the NAs, $82 \%$ of the species found were OBL (45\%), FACW (26\%), or FAC (11\%) species. Only 5\% FACU and 6\% UPL species were present. In the ROW, $84 \%$ of the species found were OBL (51\%), FACW (22\%), or FAC (11\%) species. Only 8\% FACU and 3\% UPL species were present. Thus, the vegetation in both communities consisted primarily of wetland species.

Table 11 compares species in the east and west sides of the ROW at the emergent marsh site. The two sides of the ROW were similar in total number of species ( 33 on the east and 31 on the west ROW). Seventy-three percent of the species in the ROW occurred in plots on both sides of the ROW. The two sides of the ROW were also similar in the distribution of species within the wetland indicator categories.

As shown in Table 12,63\% of the species occurring in the NAs occurred in both NAs. Sixty-seven percent of the species in the herb stratum occurred in both NAs, while $38 \%$ of the shrub species occurred in both NAs. Some of the differences between the two NAs may relate to differences in the percentage of the soil surface covered by standing water, which ranged from 5\% to $55 \%$ for plots in the ENA and from $1 \%$ to $15 \%$ for plots in the WNA.

Figure 10 is a graphic representation of the number of species by wetland indicator category and by area. Figure 11 compares the percentages of species in each category by area. Although the numbers of species are lower for the ROW, the percentages of species in the various wetland indicator categories for the combined NAs and the combined ROW are very similar.

Dominance. The dominant species for each area, by stratum, at the emergent marsh site are listed in Table 13, along with the RPC for each species, based on 10 plots per habitat. Two OBL species, blue cattail and water horsetail (Equisetum fluviatile), were dominant in the herb stratum in the NAs. Dominants in the ROW were blue cattail, broad-leaf water plantain (Alisma plantago-aquatica), and water horsetail - all OBL species. The dominant species in the shrub stratum were silky dogwood (Cornus amomum) and red-osier dogwood (Cornus stolonifera), both FACW species. No shrubs were present in the ROW.

Coefficient of Community. Table 14 shows the $\mathrm{CC}_{s}$ values between areas, by stratum, for the emergent marsh site. The two sides of the ROW were very similar $\left(\mathrm{CC}_{\mathrm{s}}\right.$ of 0.84$)$. The NAs have similar herb strata $\left(\mathrm{CC}_{s}\right.$ of 0.80$)$, but have a less similar shrub stratum $\left(\mathrm{CC}_{s}\right.$ of 0.55$)$. The lower $\mathrm{CC}_{\mathrm{s}}$ for the shrub stratum may be caused partially by actual areal differences and partially by a sample area that was insufficient to obtain an adequate sample of larger plants. Comparisons between the herb stratum of the ROW and the NAs yielded a $\mathrm{CC}_{S}$ of 0.49 . 
TABLE 10 Number of Plant Species by Wetland Indicator Category Found in the Study Plots in the NAs and the ROW (by individual stratum and combined strata) - Emergent Marsh Community

Number of Species

\begin{tabular}{|c|c|c|c|c|c|c|c|}
\hline Stratum & $\begin{array}{l}\text { Wetland } \\
\text { Indicator } \\
\text { Category }\end{array}$ & $\begin{array}{l}\text { Occurring } \\
\text { in NAs }\end{array}$ & $\begin{array}{l}\text { Occurring } \\
\text { in ROW }\end{array}$ & $\begin{array}{l}\text { Common to } \\
\text { Both Areas }\end{array}$ & $\begin{array}{l}\text { Unique } \\
\text { to NAs }\end{array}$ & $\begin{array}{l}\text { Unique } \\
\text { to ROW }\end{array}$ & Total \\
\hline \multirow[t]{7}{*}{ Herb } & OBL & 27 & 19 & 12 & 15 & 7 & 34 \\
\hline & FACW & 15 & 8 & 6 & 9 & 2 & 17 \\
\hline & FAC & 5 & 4 & 2 & 3 & 2 & 7 \\
\hline & FACU & 3 & 3 & 1 & 2 & 2 & 5 \\
\hline & UPL & 3 & 1 & 1 & 1 & 0 & 3 \\
\hline & Unida & 4 & 2 & 1 & 3 & 1 & 5 \\
\hline & TOTAL & 57 & 37 & 23 & 33 & 14 & 71 \\
\hline \multirow[t]{7}{*}{ Shrub } & OBL & 1 & 0 & 0 & 1 & 0 & 1 \\
\hline & FACW & 4 & 0 & 0 & 4 & 0 & 4 \\
\hline & FAC & 2 & 0 & 0 & 2 & 0 & 2 \\
\hline & FACU & 0 & 0 & 0 & 0 & 0 & 0 \\
\hline & UPL & 1 & 0 & 0 & 1 & 0 & 1 \\
\hline & Unid & 0 & 0 & 0 & 0 & 0 & 0 \\
\hline & TOTAL & 8 & 0 & 0 & 8 & 0 & 8 \\
\hline Combined & OBL & 28 & 19 & 13 & 15 & 6 & 34 \\
\hline \multirow[t]{6}{*}{ Stratab } & FACW & 16 & 8 & 6 & 10 & 2 & 18 \\
\hline & FAC & 7 & 4 & 2 & 5 & 2 & 9 \\
\hline & FACU & 3 & 3 & 1 & 2 & 2 & 5 \\
\hline & UPL & 4 & 1 & 1 & 3 & 0 & 4 \\
\hline & Unid & 4 & 2 & 1 & 3 & 1 & 5 \\
\hline & TOTAL & 62 & 37 & 24 & 38 & 13 & 75 \\
\hline
\end{tabular}

a Plants not identified to species or not assigned a wetland indicator category according to Reed (1988).

b When data from different strata are combined, each species is considered only once. 
TABLE 11 Number of Plant Species by Wetland Indicator Category Found in the Study Plots in the East and West Sides of the ROW (by individual stratum and combined strata) Emergent Marsh Community

Number of Species

\begin{tabular}{|c|c|c|c|c|c|c|c|}
\hline Stratum & $\begin{array}{l}\text { Wetland } \\
\text { Indicator } \\
\text { Category }\end{array}$ & $\begin{array}{c}\text { Occurring in } \\
\text { East Side of } \\
\text { ROW }\end{array}$ & $\begin{array}{c}\text { Occurring in } \\
\text { West Side of } \\
\text { ROW }\end{array}$ & $\begin{array}{c}\text { Common to } \\
\text { Both Sides } \\
\text { of ROW }\end{array}$ & $\begin{array}{l}\text { Unique to } \\
\text { East side } \\
\text { of ROW }\end{array}$ & $\begin{array}{l}\text { Unique to } \\
\text { West Side } \\
\text { of ROW }\end{array}$ & Total \\
\hline Herb & $\mathrm{OBL}$ & 17 & 16 & 14 & 3 & 2 & 19 \\
\hline and & FACW & 8 & 7 & 7 & 1 & 0 & 8 \\
\hline \multirow[t]{5}{*}{ Combined $^{\mathrm{a}}$} & FAC & 2 & 4 & 2 & 0 & 2 & 4 \\
\hline & FACU & 3 & 2 & 2 & 1 & 0 & 3 \\
\hline & UPL & 1 & 0 & 0 & 1 & 0 & 1 \\
\hline & Unid & 2 & 2 & 2 & 0 & 0 & 2 \\
\hline & TOTAL & 33 & 31 & 27 & 6 & 4 & 37 \\
\hline
\end{tabular}

a No shrubs, saplings, or trees occurred in the ROW; therefore, the herb stratum and the combined strata were the same in this case.

b Plants not identified to species.

Prevalence Index Values and Average Wetland Values. As shown in Table 15, both PIVs and AWVs for the NAs and the ROW were less than 3.00 , indicating wetland vegetation in both areas in the emergent marsh site. Values for the herb stratum were all below 2.00; PIVs for all species were lower than AWVs for all species because the dominants were all OBL species. Both the PIV and the AWV for the shrub stratum for all species were over 2.00; however, the values for dominant shrubs were both less than 2.00 . Thus, the shrub stratum was also dominated by species with a high fidelity to wetlands.

\subsubsection{Comparison of Data from 1991 and 1992}

The percentage of the soil surface covered by standing water in the NAs was $14 \%$ in 1992 compared to $33 \%$ in 1991 . However, for the ROW, the percentage of the surface covered by standing water was $39 \%$ in 1992 compared to $23 \%$ in 1991.

During pipeline construction, the vegetative mat on most of the ROW surface was destroyed. Some intact pieces of the mat (most less than one square meter) were replaced on the ROW surface during trench filling and final grading. In 1991, the sum of the average coverages for individual species was $192.4 \%$ in the as-yet undisturbed ROW; however, in 1992, the sum of the average coverages was reduced to $24.6 \%$. The sum of the average coverages for individual 
TABLE 12 Number of Plant Species by Wetland Indicator Category Found in the Study Plots in the ENA and WNA (by individual stratum and combined strata) - Emergent Marsh Community

Number of Species

\begin{tabular}{|c|c|c|c|c|c|c|c|}
\hline Stratum & $\begin{array}{l}\text { Wetland } \\
\text { Indicator } \\
\text { Category }\end{array}$ & $\begin{array}{l}\text { Occurring } \\
\text { in ENA }\end{array}$ & $\begin{array}{l}\text { Occurring } \\
\text { in WNA }\end{array}$ & $\begin{array}{l}\text { Common to } \\
\text { Both Areas }\end{array}$ & $\begin{array}{l}\text { Unique } \\
\text { to ENA }\end{array}$ & $\begin{array}{l}\text { Unique } \\
\text { to WNA }\end{array}$ & Total \\
\hline \multirow[t]{7}{*}{ Herb } & OBL & 25 & 20 & 18 & 7 & 2 & 27 \\
\hline & FACW & 13 & 13 & 11 & 2 & 2 & 15 \\
\hline & FAC & 3 & 5 & 3 & 0 & 2 & 5 \\
\hline & FACU & 3 & 2 & 2 & 1 & 0 & 3 \\
\hline & UPL & 3 & 1 & 1 & 2 & 0 & 3 \\
\hline & Unid $^{a}$ & 3 & 4 & 3 & 0 & 1 & 4 \\
\hline & TOTAL & 50 & 45 & 38 & 12 & 7 & 57 \\
\hline \multirow[t]{7}{*}{ Shrub } & OBL & 1 & 1 & 1 & 0 & 0 & 1 \\
\hline & FACW & 3 & 3 & 2 & 1 & 1 & 4 \\
\hline & FAC & 1 & 1 & 0 & 1 & 1 & 2 \\
\hline & FACU & 0 & 0 & 0 & 0 & 0 & 0 \\
\hline & UPL & 1 & 0 & 0 & 1 & 0 & 1 \\
\hline & Unid & 0 & 0 & 0 & 0 & 0 & 0 \\
\hline & TOTAL & 6 & 5 & 3 & 3 & 2 & 8 \\
\hline Combined & OBL & 26 & 21 & 19 & 7 & 2 & 28 \\
\hline \multirow[t]{6}{*}{ Stratab } & FACW & 14 & 13 & 11 & 3 & 2 & 16 \\
\hline & FAC & 4 & 6 & 3 & 1 & 3 & 7 \\
\hline & FACU & 3 & 2 & 2 & 1 & 0 & 3 \\
\hline & UPL & 4 & 1 & 1 & 3 & 0 & 4 \\
\hline & Unid & 3 & 4 & 3 & 0 & 1 & 4 \\
\hline & TOTAL & 54 & 47 & 39 & 15 & 8 & 62 \\
\hline
\end{tabular}

a Plants not identified to species or not assigned a wetland indicator category according to Reed (1988).

b When data from different strata are combined, each species is considered only once. 


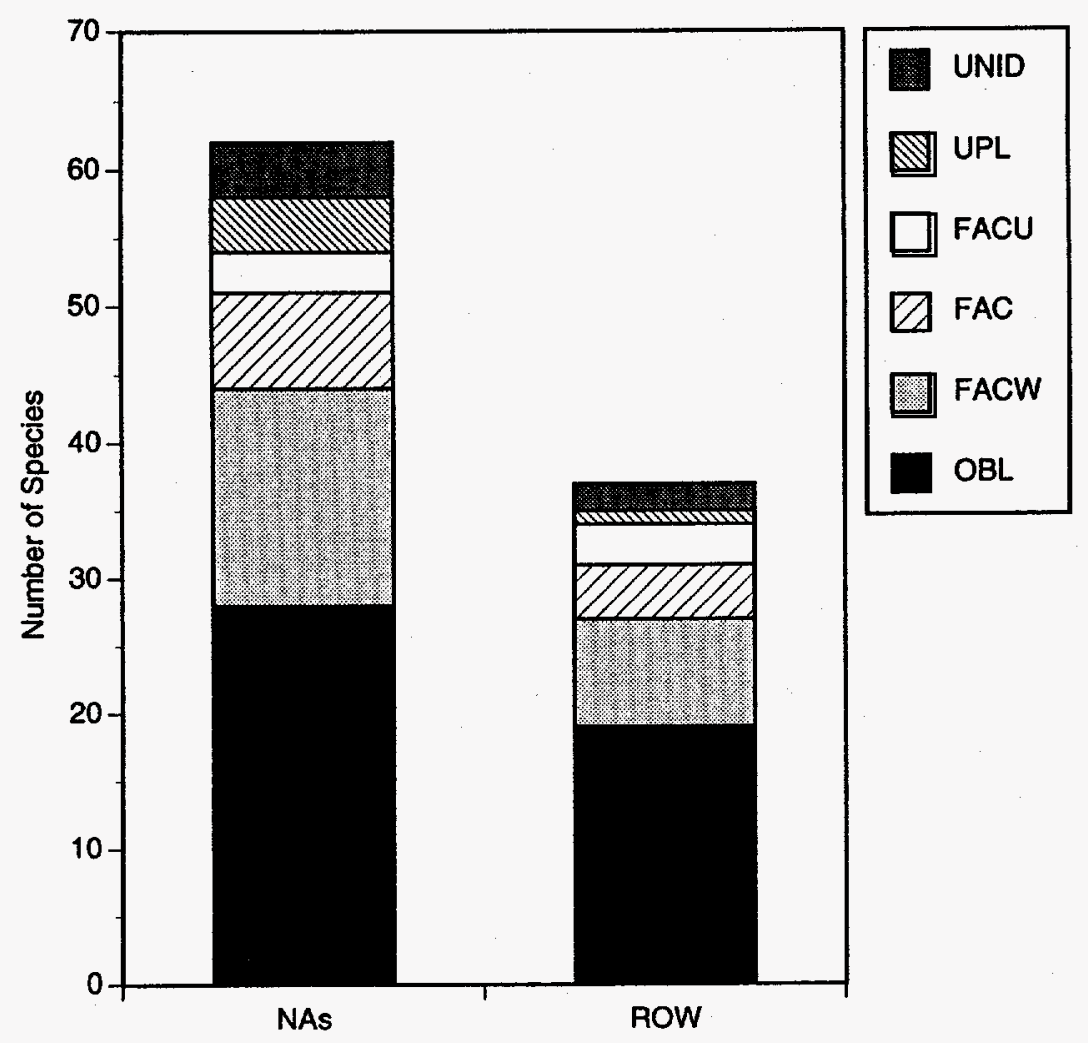

FIGURE 10 Number of Species in Each Wetland Indicator Category by Area in the Emergent Marsh Community

species in the NAs in 1991 was $183.9 \%$ compared to $193.7 \%$ in 1992 . In the shrub stratum, the sum of the average coverages for individual species in the 1991 ROW prior to pipeline installation was $54.2 \%$, compared to $0 \%$ in 1992 after pipeline installation. Shrub coverage in the NAs was $49.0 \%$ in 1991 and $50.1 \%$ in 1992 . These figures indicate little change in shrub coverage in the NAs from 1991 to 1992 , while in the ROW shrubs were eliminated.

Table 16 compares plant species present in the emergent marsh in 1991 with those present in 1992. The eight species of herbs that were present in plots at this site in 1991 but not in 1992 are listed in Appendix D, Table D.4. All of these were present in a single plot in 1991 and had coverages of less than $0.25 \%$ except grove bluegrass (Poa alsodes), which had an average coverage of $3.63 \%$. Table D.5 lists the 26 species present in 1992 but not in 1991 , and Table D.6 lists the 53 species that occurred in both 1991 and 1992. Of the 26 species newly encountered in $1992,38 \%$ were unique to the ROW, $42 \%$ were unique to the NAs, and $19 \%$ occurred in both. Only three of the species that were found only in 1992 had average coverages greater than $1 \%$. Rice cutgrass (Leersia oryzoides) had an average coverage of $3.15 \%$ in the NAs. The number of species in the ROW decreased from 48 in 1991 to 37 in 1992. 


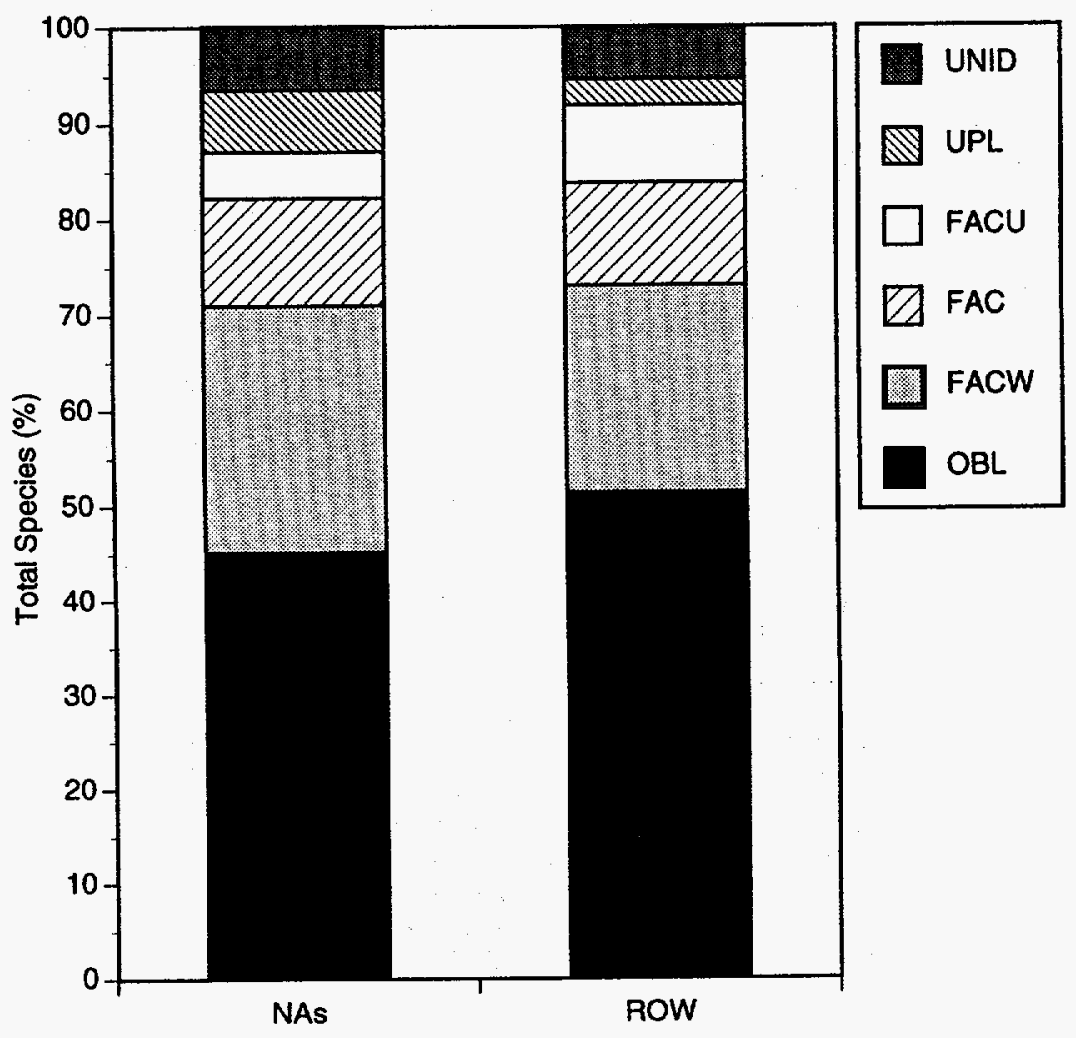

FIGURE 11 Percentage of Species in Each Wetland Indicator Category by Area in the Emergent Marsh Community

TABLE 13 Dominant Species by Vegetative Stratum for Each Habitat - Emergent Marsh Community

\begin{tabular}{|c|c|c|c|c|c|c|}
\hline Stratum & Area & $\begin{array}{c}\text { Species } \\
\text { Scientific Name }\end{array}$ & Common Name & $\begin{array}{l}\text { Wetland } \\
\text { Indicator } \\
\text { Category }\end{array}$ & $\begin{array}{l}\text { Relative } \\
\text { Percent } \\
\text { Coverage }\end{array}$ & $\begin{array}{c}\text { Sum of } \\
\text { Relative } \\
\text { Percent } \\
\text { Coverage }\end{array}$ \\
\hline \multirow[t]{5}{*}{ Herb } & NAs & Typha $\times$ glauca & Blue cattail & $\mathrm{OBL}$ & 37.6 & \\
\hline & & Equisetum fluviatile & Water horsetail & OBL & 15.0 & 52.6 \\
\hline & ROW & Typha $\times$ glauca & Blue cattail & $\mathrm{OBL}$ & 21.0 & \\
\hline & & $\begin{array}{l}\text { Alisma plantago- } \\
\text { aquatica }\end{array}$ & $\begin{array}{l}\text { Broad-leaf water } \\
\text { plantain }\end{array}$ & $\mathrm{OBL}$ & 20.6 & \\
\hline & & Equisetum fluviatile & Water horsetail & $\mathrm{OBL}$ & 17.5 & 59.1 \\
\hline \multirow[t]{2}{*}{ Shrub ${ }^{a}$} & NAs & Cornus amomum & Silky dogwood & FACW & 36.8 & \\
\hline & & Cornus stolonifera & Red-osier dogwood & FACW+ & 26.0 & 62.8 \\
\hline
\end{tabular}

a The shrub stratum is not represented in the ROW. 
TABLE 14 Coefficient of Community Values

Comparing Areas on the Basis of Species

Composition - Emergent Marsh Community

\begin{tabular}{|c|c|c|c|}
\hline \multirow[b]{2}{*}{ Stratum } & \multicolumn{3}{|c|}{ Comparison } \\
\hline & $\begin{array}{l}\text { NAs to } \\
\text { ROW }\end{array}$ & $\begin{array}{l}\text { East Side of } \\
\text { ROW to } \\
\text { West Side of } \\
\text { ROW }\end{array}$ & $\begin{array}{l}\text { ENA to } \\
\text { WNA }\end{array}$ \\
\hline Herb & 0.49 & 0.84 & 0.80 \\
\hline Shrub & 0.00 & 0.00 & 0.55 \\
\hline $\begin{array}{l}\text { Combined } \\
\text { Strata }\end{array}$ & 0.48 & 0.84 & 0.77 \\
\hline
\end{tabular}

TABLE 15 Prevalence Index Values and Average Wetland Values for All Species and Dominant Species Only in the NAs and the ROW (by individual stratum and combined strata) - Emergent Marsh Community

\begin{tabular}{|c|c|c|c|c|}
\hline Stratum & Areas & Species & $\begin{array}{l}\text { Prevalence } \\
\text { Index Value }\end{array}$ & $\begin{array}{c}\text { Average } \\
\text { Wetland Value }\end{array}$ \\
\hline \multirow[t]{4}{*}{ Herb } & NAs & All & 1.41 & 1.87 \\
\hline & & Dominant only & 1.00 & 1.00 \\
\hline & ROW & All & 1.33 & 1.83 \\
\hline & & Dominant only & 1.00 & 1.00 \\
\hline \multirow[t]{2}{*}{ Shrub } & NAs & All & 2.29 & 2.57 \\
\hline & & Dominant only & 1.59 & 1.50 \\
\hline \multirow{2}{*}{$\begin{array}{l}\text { Combined } \\
\text { Strata }\end{array}$} & NAs & All & $\mathrm{NC}^{\mathrm{a}}$ & 1.95 \\
\hline & ROWb & All & NC & 1.83 \\
\hline
\end{tabular}

a $\mathrm{NC}=$ not calculated. Values could not be calculated for combined strata because areal coverage (which is not additive) is used in its calculation.

b Only one stratum, the herb stratum, was present. 
TABLE 16 Number of Plant Species Present in 1991 Only, 1992 Only, and Both 1991 and 1992 by Wetland Indicator Category - Emergent Marsh Community

\begin{tabular}{|c|c|c|c|c|c|c|c|c|c|c|c|c|}
\hline \multirow{2}{*}{$\begin{array}{l}\text { Wetland } \\
\text { Indicator } \\
\text { Category }\end{array}$} & \multicolumn{4}{|c|}{ Present in 1991 Only } & \multicolumn{4}{|c|}{ Present in 1992 Only } & \multicolumn{4}{|c|}{ Present in 1991 and 1992} \\
\hline & $\begin{array}{l}\text { ROW } \\
\text { Only }\end{array}$ & $\begin{array}{l}\text { NAs } \\
\text { Only }\end{array}$ & Both & Total & $\begin{array}{l}\text { Row } \\
\text { Only }\end{array}$ & $\begin{array}{l}\text { NAs } \\
\text { Only }\end{array}$ & Both & Total & $\begin{array}{l}\text { ROW } \\
\text { Only }\end{array}$ & $\begin{array}{l}\text { NAs } \\
\text { Only }\end{array}$ & Botha & Total \\
\hline OBL & 0 & 1 & 0 & 1 & 4 & 4 & 2 & 10 & 0 & 4 & 22 & 26 \\
\hline FACW & 0 & 0 & 1 & 1 & 2 & 2 & 2 & 6 & 0 & 4 & 9 & 13 \\
\hline FAC & 0 & 2 & 2 & 4 & 1 & 2 & 0 & 3 & 0 & 1 & 5 & 6 \\
\hline FACU & 0 & 1 & 1 & 2 & 2 & 1 & 0 & 3 & 0 & 0 & 2 & 2 \\
\hline UPL & 0 & 0 & 0 & 0 & 0 & 1 & 0 & 1 & 0 & 0 & 3 & 3 \\
\hline Unid & 0 & 0 & 0 & 0 & 1 & 1 & 1 & 3 & 1 & 0 & 2 & 3 \\
\hline TOTAL & 0 & 4 & 4 & 8 & 10 & 11 & 5 & 26 & 1 & 9 & 43 & 53 \\
\hline
\end{tabular}

a Occurred in both NAs and ROW, either in one year or in both years together. 
Table 17 gives $\mathrm{CC}_{\mathrm{s}}$ values comparing the species in the emergent marsh NAs and ROW between 1991 and 1992. The $\mathrm{CC}_{\mathrm{s}}$ comparing the herb stratum species present in the ROW in 1991 and 1992 was only slightly less than the comparable value for the NAs. Removal of the shrubs from the ROW is reflected by a $\mathrm{CC}_{\mathrm{s}}$ of 0.00 , compared to 0.94 for the shrub stratum in the NAs.

Table 18 compares the PIVs and the AWVs in the emergent marsh NAs and ROW, by stratum, for all species and for dominants only. Both the PIV and AWV for all species in the NAs and in the ROW tended to be slightly lower in 1992 than in 1991. Values for dominant species in the herb stratum were much lower in 1992 because the dominants were all OBL species. PIVs and AWVs for the shrub stratum in the NAs were very similar for 1991 and 1992 . Because no shrubs or trees were found in the ROW in 1992, no comparisons could be made for these strata in the ROW.

\subsection{Forested Wetland Community}

\subsubsection{General Ecology}

The forested wetland community is located east of the scrub-shrub community along the pipeline ROW (Figure 2). As the ROW proceeds east from the scrub-shrub community, it passes through an area of mixed shrubs and trees, then through a forested wetland community that soon intergrades into lowland forest. The beaver dam occurs approximately where the scrub-shrub community changes into mixed shrubs and trees. Thus, the forested wetland community had not been submerged by the beaver dam.

TABLE 17 Coefficient of Community Values

Comparing 1991 and 1992 Data on the Basis

of Species Composition - Emergent Marsh

Community

\begin{tabular}{|c|c|c|}
\hline \multirow[b]{3}{*}{ Stratum } & \multicolumn{2}{|c|}{ Comparison } \\
\hline & NAs & ROW \\
\hline & 1991 to 1992 & 1991 to 1992 \\
\hline Herb & 0.70 & 0.65 \\
\hline Shrub & 0.94 & 0.00 \\
\hline $\begin{array}{l}\text { Combined } \\
\text { Strata }\end{array}$ & 0.75 & 0.65 \\
\hline
\end{tabular}


TABLE 18 Prevalence Index and Average Wetland Values for All Species and Dominant Species Only in the NAs and the ROW (by individual stratum and combined strata) - Emergent Marsh Community

\begin{tabular}{|c|c|c|c|c|c|c|}
\hline \multirow[b]{2}{*}{ Stratum } & \multirow[b]{2}{*}{ Area } & \multirow[b]{2}{*}{ Species } & \multicolumn{2}{|c|}{$\begin{array}{l}\text { Prevalence } \\
\text { Index Value }\end{array}$} & \multicolumn{2}{|c|}{$\begin{array}{c}\text { Average } \\
\text { Wetland Value }\end{array}$} \\
\hline & & & 1991 & 1992 & 1991 & 1992 \\
\hline \multirow[t]{4}{*}{ Herb } & NAs & All & 1.55 & 1.41 & 1.90 & 1.87 \\
\hline & & Dominant only & 1.59 & 1.00 & 2.00 & 1.00 \\
\hline & ROW & AlI & 1.60 & 1.33 & 1.98 & 1.83 \\
\hline & & Dominant only & 1.63 & 1.00 & 2.00 & 1.00 \\
\hline \multirow[t]{4}{*}{ Shrub } & NAs & All & 2.05 & 2.29 & 2.56 & 2.57 \\
\hline & & Dominant only & 1.64 & 1.59 & 1.67 & 1.50 \\
\hline & ROWa & All & 2.27 & none & 2.50 & none \\
\hline & & Dominant only & 1.66 & none & 1.50 & none \\
\hline \multirow[t]{3}{*}{ Tree } & $N A s^{b}$ & & none & none & none & none \\
\hline & ROWa & All & 3.00 & none & 3.00 & none \\
\hline & & Dominant only & 3.00 & none & 3.00 & none \\
\hline Combined & NAs & All & $N C^{c}$ & NC & 2.00 & 1.97 \\
\hline Strata & ROW & All & NC & NC & 1.98 & 1.83 \\
\hline
\end{tabular}

a No shrubs or trees were present on the ROW in 1992.

b No trees were present in the NAs in 1991 and 1992.

c $N C=$ not calculated. Values could not be calculated for combined strata because areal coverage (which is not additive) is used in its calculation. 
Because of the limited extent of forested wetland along the pipeline route, only one transect was sampled. The west edge of the transect was approximately $100 \mathrm{~m}$ east of the last scrub-shrub transect. The SNA along the transect sloped upward slightly to the south. No shrubs, saplings, or trees were observed in the ROW. At the time of sampling, the NAs on either side of the ROW contained no standing water; however, about $39 \%$ of the ROW surface was covered with standing water. Approximately $75 \%$ of the north side of the ROW was covered with standing water, while on the south side only $2 \%$ of the surface was submerged. Slash, partially covered with soil, remained on the south portion of the ROW. The soils are mapped as Lamson.

\subsubsection{Plant Community}

A total of 65 taxa of vascular plants occurred within the forested wetland transect. Of these, 62 were identified to species. Table C.7 lists these taxa with common names, wetland indicator categories, and life-forms and origins (Reed 1988). The 65 taxa consisted of one horsetail, three ferns, seven sedges, two rushes, four grasses, twenty-eight forbs, three vines, ten shrubs, and seven trees. Table C.8 provides the distribution and areal coverage for the NAs and for the two sides of the ROW. Ten introduced species were identified: one grass, five forbs, three shrubs, and one tree. Although all introduced species occurred in the ROW, only two were limited to the ROW. (See Appendix B, Section B.2, for definitions of the symbols used to represent lifeforms and origins.)

Species Richness and Wetland Indicator Categories. Table 19 gives the number of species by wetland indicator category and by stratum found in the NAs and in the ROW at the forested wetland site. Of the 65 species identified, $91 \%$ occurred in the NAs. Thirty-two percent of the species occurred in the ROW, and 9\% were unique to the ROW. All 65 species were represented in the herb stratum. Only four were present in the shrub stratum, two in the sapling stratum, and four in the tree stratum. Sixty-two percent of the species were OBL (31\%) or FACW (31\%) species; $14 \%$ were FAC, $14 \%$ FACU, and $5 \%$ were UPL species.

None of the 21 herb species identified in the forested wetland ROW occurred in both sides of the ROW (Table 20). Vegetation on the ROW was sparse and the two sides were quite different. Only OBL species occurred on the north side of the ROW; three FACU and one UPL species were present on soil associated with and elevated by the slash logs left from pipeline construction on the south side of the ROW.

As shown in Table 21, only $36 \%$ of the 59 species found in the forested wetland NAs occurred in both the NNA and SNA sampling plots. All species were present in the herb stratum with the same distributions as when all strata were considered together. Eighty-one percent of the species occurred in the SNA while 54\% occurred in the NNA. Seventy-nine percent of the species in the NAs were OBL (30\%), FACW (34\%), or FAC (15\%) species; 15\% were FACU or UPL species. 
TABLE 19 Number of Plant Species by Wetland Indicator Category Found in the Study Plots in the NAs and the ROW (by individual stratum and combined strata) - Forested Wetland Community

\begin{tabular}{|c|c|c|c|c|c|c|c|}
\hline \multirow[b]{2}{*}{ Stratum } & \multirow{2}{*}{$\begin{array}{l}\text { Wetland } \\
\text { Indicator } \\
\text { Category }\end{array}$} & \multicolumn{6}{|c|}{ Number of Species } \\
\hline & & $\begin{array}{l}\text { Occurring } \\
\text { in NAs }\end{array}$ & $\begin{array}{l}\text { Occurring } \\
\text { in ROW }\end{array}$ & $\begin{array}{l}\text { Common to } \\
\text { Both Areas }\end{array}$ & $\begin{array}{l}\text { Unique } \\
\text { to NAs }\end{array}$ & $\begin{array}{l}\text { Unique } \\
\text { to ROW }\end{array}$ & Total \\
\hline Herb & $\begin{array}{l}\text { OBL } \\
\text { FACW } \\
\text { FAC } \\
\text { FACU } \\
\text { UPL } \\
\text { NIa } \\
\text { Unid } \\
\text { TOTAL }\end{array}$ & $\begin{array}{r}17 \\
20 \\
9 \\
7 \\
2 \\
1 \\
3 \\
59\end{array}$ & $\begin{array}{r}11 \\
5 \\
1 \\
3 \\
1 \\
0 \\
0 \\
21\end{array}$ & $\begin{array}{r}8 \\
5 \\
1 \\
1 \\
0 \\
0 \\
0 \\
15\end{array}$ & $\begin{array}{r}9 \\
15 \\
8 \\
6 \\
2 \\
1 \\
3 \\
44\end{array}$ & $\begin{array}{l}3 \\
0 \\
0 \\
2 \\
1 \\
0 \\
0 \\
6\end{array}$ & $\begin{array}{r}20 \\
20 \\
9 \\
9 \\
3 \\
1 \\
3 \\
65\end{array}$ \\
\hline Shrub & $\begin{array}{l}\text { OBL } \\
\text { FACW } \\
\text { FAC } \\
\text { FACU } \\
\text { UPL } \\
\text { Unid } \\
\text { TOTAL }\end{array}$ & $\begin{array}{l}0 \\
3 \\
0 \\
0 \\
1 \\
0 \\
4\end{array}$ & $\begin{array}{l}0 \\
0 \\
0 \\
0 \\
0 \\
0 \\
0\end{array}$ & $\begin{array}{l}0 \\
0 \\
0 \\
0 \\
0 \\
0 \\
0\end{array}$ & $\begin{array}{l}0 \\
3 \\
0 \\
0 \\
1 \\
0 \\
4\end{array}$ & $\begin{array}{l}0 \\
0 \\
0 \\
0 \\
0 \\
0 \\
0\end{array}$ & $\begin{array}{l}0 \\
3 \\
0 \\
0 \\
1 \\
0 \\
4\end{array}$ \\
\hline Sapling & $\begin{array}{l}\text { OBL } \\
\text { FACW } \\
\text { FAC } \\
\text { FACU } \\
\text { UPL } \\
\text { Unid } \\
\text { TOTAL }\end{array}$ & $\begin{array}{l}0 \\
1 \\
0 \\
0 \\
1 \\
0 \\
2\end{array}$ & $\begin{array}{l}0 \\
0 \\
0 \\
0 \\
0 \\
0 \\
0\end{array}$ & $\begin{array}{l}0 \\
0 \\
0 \\
0 \\
0 \\
0 \\
0\end{array}$ & $\begin{array}{l}0 \\
1 \\
0 \\
0 \\
1 \\
0 \\
2\end{array}$ & $\begin{array}{l}0 \\
0 \\
0 \\
0 \\
0 \\
0 \\
0\end{array}$ & $\begin{array}{l}0 \\
1 \\
0 \\
0 \\
1 \\
0 \\
2\end{array}$ \\
\hline Tree & $\begin{array}{l}\text { OBL } \\
\text { FACW } \\
\text { FAC } \\
\text { FACU } \\
\text { UPL } \\
\text { Unid } \\
\text { TOTAL }\end{array}$ & $\begin{array}{l}0 \\
3 \\
1 \\
0 \\
0 \\
0 \\
4\end{array}$ & $\begin{array}{l}0 \\
0 \\
0 \\
0 \\
0 \\
0 \\
0\end{array}$ & $\begin{array}{l}0 \\
0 \\
0 \\
0 \\
0 \\
0 \\
0\end{array}$ & $\begin{array}{l}0 \\
3 \\
1 \\
0 \\
0 \\
0 \\
4\end{array}$ & $\begin{array}{l}0 \\
0 \\
0 \\
0 \\
0 \\
0 \\
0\end{array}$ & $\begin{array}{l}0 \\
3 \\
1 \\
0 \\
0 \\
0 \\
4\end{array}$ \\
\hline $\begin{array}{l}\text { Combined } \\
\text { Strata }^{c}\end{array}$ & $\begin{array}{l}\text { OBL } \\
\text { FACW } \\
\text { FAC } \\
\text { FACU } \\
\text { UPL } \\
\mathrm{Nl}^{\mathrm{a}} \\
\text { Unid } \\
\text { TOTAL }\end{array}$ & $\begin{array}{r}17 \\
20 \\
9 \\
7 \\
2 \\
1 \\
3 \\
59\end{array}$ & $\begin{array}{r}11 \\
5 \\
1 \\
3 \\
1 \\
0 \\
0 \\
21\end{array}$ & $\begin{array}{r}8 \\
5 \\
1 \\
1 \\
0 \\
0 \\
0 \\
15\end{array}$ & $\begin{array}{r}9 \\
15 \\
8 \\
6 \\
2 \\
1 \\
3 \\
44\end{array}$ & $\begin{array}{l}3 \\
0 \\
0 \\
2 \\
1 \\
0 \\
0 \\
6\end{array}$ & $\begin{array}{r}20 \\
20 \\
9 \\
9 \\
3 \\
1 \\
3 \\
65\end{array}$ \\
\hline
\end{tabular}

a Identified species of plants for which an indicator status has not yet been determined.

b Plants not identified to species or not assigned a wetland indicator category according to Reed (1988).

c When data from different strata are combined, each species is considered only once. 
TABLE 20 Number of Plant Species by Wetland Indicator Category Found in the Study Plots in the North and South Sides of the ROW (by individual stratum and combined strata) - Forested Wetland Community

\begin{tabular}{|c|c|c|c|c|c|c|c|}
\hline \multirow[b]{2}{*}{ Stratum } & \multirow[b]{2}{*}{$\begin{array}{l}\text { Wetland } \\
\text { Indicator } \\
\text { Category }\end{array}$} & \multicolumn{6}{|c|}{ Number of Species } \\
\hline & & $\begin{array}{l}\text { Occurring } \\
\text { in North } \\
\text { Side of } \\
\text { ROW }\end{array}$ & $\begin{array}{l}\text { Occurring } \\
\text { in South } \\
\text { Side of } \\
\text { ROW }\end{array}$ & $\begin{array}{c}\text { Common to } \\
\text { Both Sides } \\
\text { of ROW }\end{array}$ & $\begin{array}{l}\text { Unique } \\
\text { to North } \\
\text { Side of } \\
\text { ROW }\end{array}$ & $\begin{array}{l}\text { Unique } \\
\text { to South } \\
\text { Side of } \\
\text { ROW }\end{array}$ & Total \\
\hline Herb and & $\mathrm{OBL}$ & 4 & 7 & 0 & 4 & 7 & 11 \\
\hline \multirow[t]{6}{*}{ Combined ${ }^{a}$} & FACW & 0 & 5 & 0 & 0 & 5 & 5 \\
\hline & FAC & 0 & 1 & 0 & 0 & 1 & 1 \\
\hline & FACU & 0 & 3 & 0 & 0 & 3 & 3 \\
\hline & UPL & 0 & 1 & 0 & 0 & 1 & 1 \\
\hline & Unid ${ }^{b}$ & 0 & 0 & 0 & 0 & 0 & 0 \\
\hline & TOTAL & 4 & 17 & 0 & 4 & 17 & 21 \\
\hline
\end{tabular}

a No shrubs, saplings, or trees occurred in the ROW; therefore, the herb stratum and the combined strata were the same in this case.

b Plants not identified to species.

Figures 12 and 13 compare species in the forested wetland by wetland indictor categories and by area. The lower number of species on the ROW is obvious in Figure 12; however, the percentage of OBL species on the ROW is higher. Eighty-one percent of the species on the ROW were OBL, FACW, and FAC species, while $78 \%$ of the species in the NAs were included in these categories.

Dominance. Table 22 lists the dominant species and their associated RPCs, by stratum, for the forested wetland. In the herb stratum of the NAs, five species qualified as dominants. One was the introduced common buckthorn (Rhamnus cathartica), a UPL species. The others were native species with wetland indicators ranging from OBL to FAC. Blue cattail, an OBL species, was the only herb dominant in the ROW.

Shrub, sapling, and tree strata occurred only in the NAs. Common buckthorn was dominant in the shrub stratum of the NAs. Silver maple, a FACW species, occurred as the dominant sapling; the only other sapling, common buckthorn, was a co-dominant. Silver maple was the leading dominant in the tree stratum and crack willow, a FAC species, was a co-dominant.

Coefficient of Community. A comparison of the combined NAs with the combined ROWs gave a $\mathrm{CC}_{\mathrm{s}}$ value of 0.38 for the forested wetland community (Table 23). Because the two 
TABLE 21 Number of Plant Species by Wetland Indicator Category Found in the Study Plots in the NNA and SNA (by individual stratum and combined strata) - Forested Wetland Community

\begin{tabular}{|c|c|c|c|c|c|c|c|}
\hline \multirow[b]{2}{*}{ Stratum } & \multirow{2}{*}{$\begin{array}{l}\text { Wetland } \\
\text { Indicator } \\
\text { Category }\end{array}$} & \multicolumn{6}{|c|}{ Number of Species } \\
\hline & & $\begin{array}{l}\text { Occurring } \\
\text { in NNA }\end{array}$ & $\begin{array}{c}\text { Occurring } \\
\text { in SNA }\end{array}$ & $\begin{array}{l}\text { Common to } \\
\text { Both Areas }\end{array}$ & $\begin{array}{l}\text { Unique } \\
\text { to NNA }\end{array}$ & $\begin{array}{l}\text { Unique } \\
\text { to SNA }\end{array}$ & Total \\
\hline Herb & $\begin{array}{l}\text { OBL } \\
\text { FACW } \\
\text { FAC } \\
\text { FACU } \\
\text { UPL } \\
\text { NIa } \\
\text { Unid }^{b} \\
\text { TOTAL }\end{array}$ & $\begin{array}{r}8 \\
10 \\
6 \\
4 \\
2 \\
0 \\
2 \\
32\end{array}$ & $\begin{array}{r}13 \\
19 \\
6 \\
6 \\
1 \\
1 \\
2 \\
48\end{array}$ & $\begin{array}{r}4 \\
9 \\
3 \\
3 \\
1 \\
0 \\
1 \\
21\end{array}$ & $\begin{array}{r}4 \\
1 \\
3 \\
1 \\
1 \\
0 \\
1 \\
11\end{array}$ & $\begin{array}{r}9 \\
10 \\
3 \\
3 \\
0 \\
1 \\
1 \\
27\end{array}$ & $\begin{array}{r}17 \\
20 \\
9 \\
7 \\
2 \\
1 \\
3 \\
59\end{array}$ \\
\hline Shrub & $\begin{array}{l}\text { OBL } \\
\text { FACW } \\
\text { FAC } \\
\text { FACU } \\
\text { UPL } \\
\text { Unid } \\
\text { TOTAL }\end{array}$ & $\begin{array}{l}0 \\
3 \\
0 \\
0 \\
1 \\
0 \\
4\end{array}$ & $\begin{array}{l}0 \\
1 \\
0 \\
0 \\
1 \\
0 \\
2\end{array}$ & $\begin{array}{l}0 \\
1 \\
0 \\
0 \\
1 \\
0 \\
2\end{array}$ & $\begin{array}{l}0 \\
2 \\
0 \\
0 \\
0 \\
0 \\
2\end{array}$ & $\begin{array}{l}0 \\
0 \\
0 \\
0 \\
0 \\
0 \\
0\end{array}$ & $\begin{array}{l}0 \\
3 \\
0 \\
0 \\
1 \\
0 \\
4\end{array}$ \\
\hline Sapling & $\begin{array}{l}\text { OBL } \\
\text { FACW } \\
\text { FAC } \\
\text { FACU } \\
\text { UPL } \\
\text { Unid } \\
\text { TOTAL }\end{array}$ & $\begin{array}{l}0 \\
1 \\
0 \\
0 \\
1 \\
0 \\
2\end{array}$ & $\begin{array}{l}0 \\
1 \\
0 \\
0 \\
0 \\
0 \\
1\end{array}$ & $\begin{array}{l}0 \\
1 \\
0 \\
0 \\
0 \\
0 \\
1\end{array}$ & $\begin{array}{l}0 \\
0 \\
0 \\
0 \\
1 \\
0 \\
1\end{array}$ & $\begin{array}{l}0 \\
0 \\
0 \\
0 \\
0 \\
0 \\
0\end{array}$ & $\begin{array}{l}0 \\
1 \\
0 \\
0 \\
1 \\
0 \\
2\end{array}$ \\
\hline Tree & $\begin{array}{l}\text { OBL } \\
\text { FACW } \\
\text { FAC } \\
\text { FACU } \\
\text { UPL } \\
\text { Unid } \\
\text { TOTAL }\end{array}$ & $\begin{array}{l}0 \\
2 \\
0 \\
0 \\
0 \\
0 \\
2\end{array}$ & $\begin{array}{l}0 \\
3 \\
1 \\
0 \\
0 \\
0 \\
4\end{array}$ & $\begin{array}{l}0 \\
2 \\
0 \\
0 \\
0 \\
0 \\
2\end{array}$ & $\begin{array}{l}0 \\
0 \\
0 \\
0 \\
0 \\
0 \\
0\end{array}$ & $\begin{array}{l}0 \\
1 \\
1 \\
0 \\
0 \\
0 \\
2\end{array}$ & $\begin{array}{l}0 \\
3 \\
1 \\
0 \\
0 \\
0 \\
4\end{array}$ \\
\hline $\begin{array}{l}\text { Combined } \\
\text { Strata }^{c}\end{array}$ & $\begin{array}{l}\text { OBL } \\
\text { FACW } \\
\text { FAC } \\
\text { FACU } \\
\text { UPL } \\
\text { NI } \\
\text { Unid } \\
\text { TOTAL }\end{array}$ & $\begin{array}{r}8 \\
10 \\
6 \\
4 \\
2 \\
0 \\
2 \\
32\end{array}$ & $\begin{array}{r}13 \\
19 \\
6 \\
6 \\
1 \\
1 \\
2 \\
48\end{array}$ & $\begin{array}{r}4 \\
9 \\
3 \\
3 \\
1 \\
0 \\
1 \\
21\end{array}$ & $\begin{array}{r}4 \\
1 \\
3 \\
1 \\
1 \\
0 \\
1 \\
11\end{array}$ & $\begin{array}{r}9 \\
10 \\
3 \\
3 \\
0 \\
1 \\
1 \\
27\end{array}$ & $\begin{array}{r}17 \\
20 \\
9 \\
7 \\
2 \\
1 \\
3 \\
59\end{array}$ \\
\hline
\end{tabular}

a Identified plant species for which an indicator status has not yet been determined.

b Plants not identified to species.

c When data from different strata are combined, each species is considered only once. 


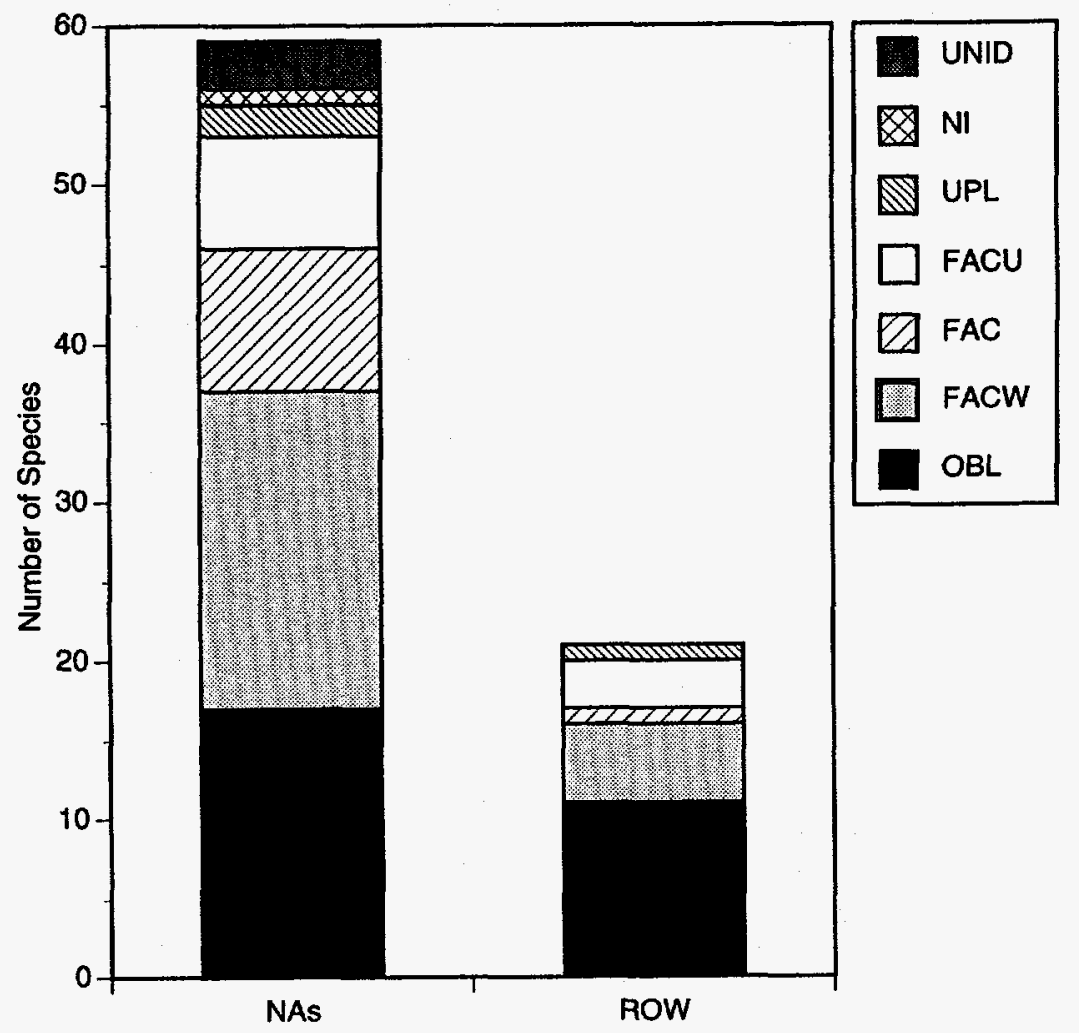

FIGURE 12 Number of Species in Each Wetland Indicator Category by Area in the Forested Wetland Community

sides of the ROW shared no species in common, their $\mathrm{CC}_{\mathrm{s}}$ was 0.00 . The $\mathrm{CC}_{\mathrm{s}}$ comparing the two NAs was low, 0.53 for both the herb stratum and for all strata combined. The $\mathrm{CC}_{\mathrm{s}}$ for the NNA and SNA was the same $(0.67)$ for the shrub, sapling, and tree strata.

Prevalence Index Values and Average Wetland Values. Table 24 provides the AWVs and PIVs for the NAs and the ROW in the forested wetland community. Both AWVs and PIVs for all species and dominant species only in the herb stratum are lower for the ROW than for the NAs. No comparisons can be made between the NAs and the ROW for the shrub, sapling, and tree strata because these strata did not occur in the ROW. The shrub stratum was dominated by common buckthorn, a UPL species, causing an AWV and a PIV for dominants of 5.00. PIVs for all species and for dominants only in the herb, sapling, and tree strata were below 3.00 , indicating wetland vegetation in these strata. 


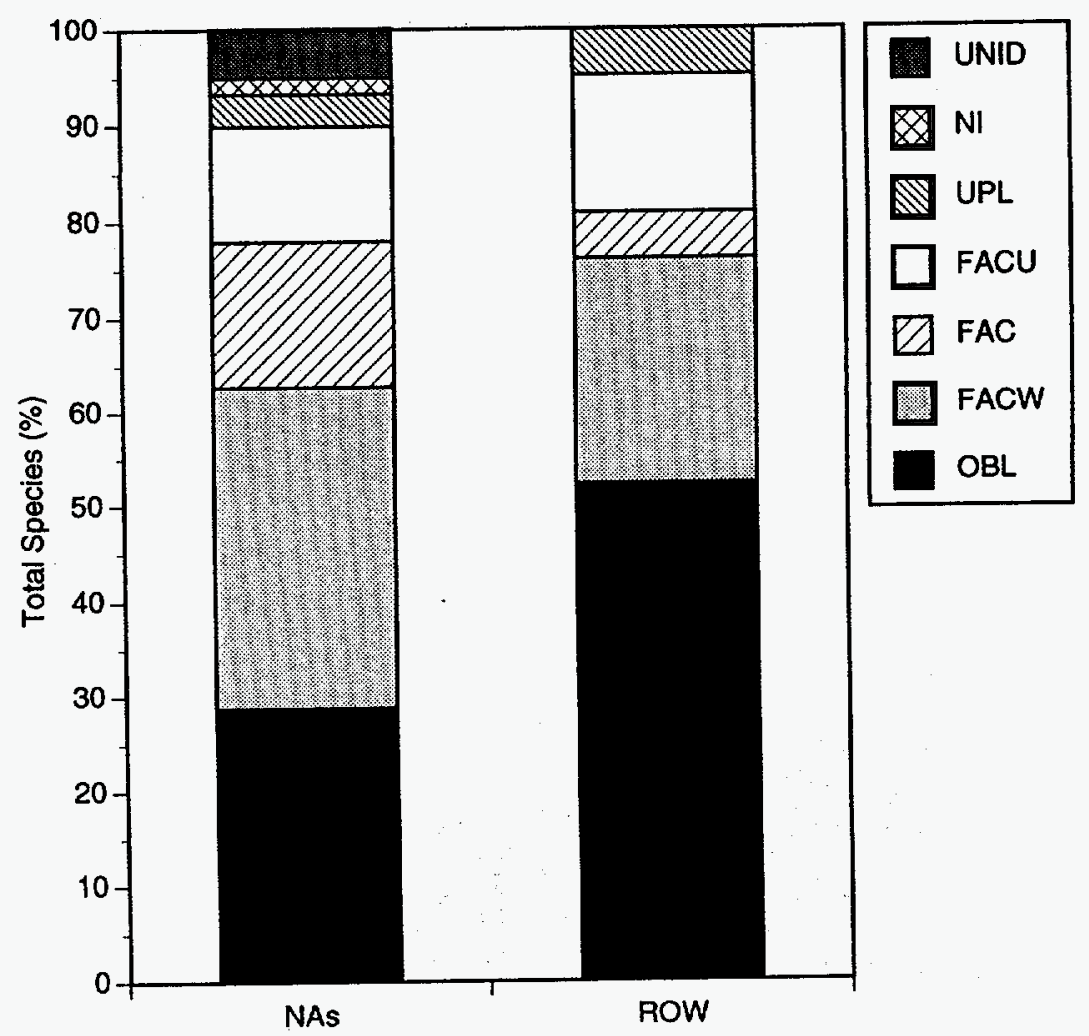

FIGURE 13 Percentage of Species in Each Wetland Indicator Category by Area in the Forested Wetland Community

TABLE 22 Dominant Species by Vegetative Stratum - Forested Wetland Community

\begin{tabular}{|c|c|c|c|c|c|c|}
\hline Stratum & Area & $\begin{array}{c}\text { Species } \\
\text { Scientific Name }\end{array}$ & Common Name & $\begin{array}{l}\text { Wetland } \\
\text { Indicator } \\
\text { Category }\end{array}$ & $\begin{array}{l}\text { Relative } \\
\text { Percent } \\
\text { Coverage }\end{array}$ & $\begin{array}{l}\text { Sum of } \\
\text { Relative } \\
\text { Percent } \\
\text { Coverage }\end{array}$ \\
\hline Herb & NAs & $\begin{array}{l}\text { Onoclea sensibilis } \\
\text { Rhamnus cathartica } \\
\text { Glyceria striata } \\
\text { Impatiens capensis } \\
\text { Toxicodendron radians }\end{array}$ & $\begin{array}{l}\text { Sensitive fern } \\
\text { Common buckthorn } \\
\text { Fowl manna grass } \\
\text { Spotted touch-me-not } \\
\text { Poison ivy }\end{array}$ & $\begin{array}{l}\text { FACW } \\
\text { UPL } \\
\text { OBL } \\
\text { FACW } \\
\text { FAC }\end{array}$ & $\begin{array}{r}22.2 \\
11.3 \\
9.6 \\
6.1 \\
3.9\end{array}$ & 53.1 \\
\hline & ROW & Typha $\times$ glauca & Blue cattail & OBL & 61.5 & 61.5 \\
\hline Shrub & NAs & Rhamnus cathartica & Common buckthorn & UPL & 80.7 & 80.7 \\
\hline Sapling & NAs & $\begin{array}{l}\text { Acer saccharinum } \\
\text { Rhamnus cathartica }\end{array}$ & $\begin{array}{l}\text { Silver maple } \\
\text { Common buckthom }\end{array}$ & $\begin{array}{l}\text { FACW } \\
\text { UPL }\end{array}$ & $\begin{array}{l}75.0 \\
25.0\end{array}$ & 100.0 \\
\hline Tree & NAs & $\begin{array}{l}\text { Acer saccharinum } \\
\text { Salix fragilis }\end{array}$ & $\begin{array}{l}\text { Silver maple } \\
\text { Crack willow }\end{array}$ & $\begin{array}{l}\text { FACW } \\
\text { FAC }\end{array}$ & $\begin{array}{l}64.0 \\
32.0\end{array}$ & 96.0 \\
\hline
\end{tabular}


TABLE 23 Coefficient of Community Values

Comparing Areas on the Basis of Species

Composition - Forested Wetland Community

\begin{tabular}{lccc}
\hline & \multicolumn{3}{c}{ Comparison } \\
\cline { 2 - 4 } Stratum & $\begin{array}{c}\text { NAs to } \\
\text { ROW }\end{array}$ & $\begin{array}{c}\text { North ROW to } \\
\text { South ROW }\end{array}$ & $\begin{array}{c}\text { NNA to } \\
\text { SNA }\end{array}$ \\
\hline Herb & 0.38 & 0.00 & 0.53 \\
Shrub & 0.00 & NC & 0.67 \\
Sapling & 0.00 & NC & 0.67 \\
Tree & 0.00 & NC & 0.67 \\
Combined & 0.38 & 0.00 & 0.53 \\
Strata & & & \\
\hline
\end{tabular}

a $\mathrm{NC}=$ not calculated. Only the herb stratum was present in the ROW.

\subsubsection{Comparison of Data from 1991 and 1992}

Obvious construction effects in the 1991 ROW included embedded logs in the soil surface on the working (south) side of the ROW (constituting about $7 \%$ of the ROW surface), standing water (covering about $40 \%$ of the soil surface), and exposed, disturbed soils that remained unvegetated. None of these were present prior to construction of the 1991 pipeline.

Table 25 compares species present in 1991 and 1992 by wetland indicator category for the forested wetland community. The numbers of species in the OBL and FACW categories were much higher in 1992. Of the 78 species encountered in plots in this site over the two years, $17 \%$ were identified only in 1991 (Table D.7), 59\% were identified only in 1992 (Table D.8), and $24 \%$ occurred in the sampling plots during both years (Table D.9). The number of species in the ROW decreased from 26 in 1991 to 21 in 1992 . The total number of species in the ROW in 1992, therefore, was $81 \%$ of the number in 1991 . The total number of species in the NAs increased from 27 in 1991 to 59 in 1992, a $120 \%$ increase. Seventy-one percent of the species found in the ROW in 1992 also occurred in the NAs.

The vegetational community that existed on the ROW prior to installation of the 1991 pipeline was substantially altered. The $\mathrm{CC}_{s}$ values listed in Table 26 , comparing forested wetland species data from 1991 and 1992, are all low. The $\mathrm{CC}_{\mathrm{s}}$ for the herb stratum (the only stratum present on the two sides of the ROW) was only 0.13 , with only three species in common between 
TABLE 24 Prevalence Index and Average Wetland Values for All Species and Dominant Species Only in the NAs and the ROW (by individual stratum and combined strata) - Forested Wetland Community

\begin{tabular}{|c|c|c|c|c|}
\hline Stratum & Areas & Species & $\begin{array}{l}\text { Prevalence } \\
\text { Index Value }\end{array}$ & $\begin{array}{c}\text { Average } \\
\text { Wetland Value }\end{array}$ \\
\hline \multirow[t]{4}{*}{ Herb } & NAs & All & 2.36 & 2.35 \\
\hline & & Dominant only & 2.71 & 2.60 \\
\hline & ROW & All & 1.39 & 1.95 \\
\hline & & Dominant only & 1.00 & 1.00 \\
\hline \multirow[t]{2}{*}{ Shrub } & NAs & All & 4.42 & 2.75 \\
\hline & & Dominant only & 5.00 & 5.00 \\
\hline \multirow[t]{2}{*}{ Sapling } & NAs & All & 2.75 & 3.50 \\
\hline & & Dominant only & 2.75 & 3.50 \\
\hline \multirow[t]{2}{*}{ Tree } & NAs & All & 2.32 & 2.25 \\
\hline & & $\begin{array}{l}\text { Dominant } \\
\text { only }\end{array}$ & 2.33 & 2.50 \\
\hline \multirow{2}{*}{$\begin{array}{l}\text { Combined } \\
\text { Strata }\end{array}$} & NAs & All & $\mathrm{NCa}$ & 2.35 \\
\hline & ROW & AlI & NC & 1.95 \\
\hline
\end{tabular}

a $\mathrm{NC}=$ not calculated. Values could not be calculated for combined strata because areal cover (which is not additive) is used in its calculation.

the two sampling events. Spotted touch-me-not (Impatiens capensis), which had an average coverage of $26 \%$ in the two ROW plots in 1991, had an average coverage of $1.5 \%$ in 1992 . Blue cattail, which was not present on the site in 1991, had an average coverage of $10 \%$ in 1992 and was the leading dominant on the ROW.

Forested wetland PIVs and AWVs for both NA and ROW vegetation (like the values for the scrub-shrub and emergent marsh) were similar for 1991 and 1992. Table 27 lists PIVs and AWVs by stratum for all species and for dominants only for 1991 and 1992. Comparing values for the two years reveals only small changes - except for changes in values resulting from the removal of shrub, sapling, and tree strata from the ROW. 
TABLE 25 Number of Plant Species Present in 1991 Only, 1992 Only, and Both 1991 and 1992 by Wetland Indicator Category - Forested Wetland Community

\begin{tabular}{|c|c|c|c|c|c|c|c|c|c|c|c|}
\hline \multirow{2}{*}{$\begin{array}{l}\text { Wetland } \\
\text { Indicator } \\
\text { Category }\end{array}$} & \multicolumn{4}{|c|}{ Present in 1991 Only } & \multicolumn{4}{|c|}{ Present in 1992 Only } & \multicolumn{3}{|c|}{$\begin{array}{c}\text { Present in } 1991 \\
\text { and } 1992 \\
\end{array}$} \\
\hline & ROW & NAs & Both & Total & ROW & NAs & Both & Total & NAs & Botha & Tota \\
\hline $\mathrm{OBL}$ & 0 & 0 & 0 & 0 & 3 & 7 & 7 & 17 & 0 & 3 & 3 \\
\hline FACW & 0 & 0 & 2 & 2 & 0 & 7 & 3 & 10 & 0 & 9 & 9 \\
\hline FAC & 1 & 2 & 2 & 5 & 0 & 5 & 1 & 6 & 1 & 2 & 3 \\
\hline FACU & 1 & 1 & 1 & 3 & 2 & 4 & 1 & 7 & 0 & 3 & 3 \\
\hline UPL & 0 & 0 & 0 & 0 & 1 & 2 & 0 & 3 & 0 & 1 & 1 \\
\hline Unid $^{b}$ & 0 & 2 & 1 & 3 & 0 & 2 & 0 & 2 & 0 & 0 & 0 \\
\hline$N I^{c}$ & 0 & 0 & 0 & 0 & 0 & 1 & 0 & 1 & 0 & 0 & 0 \\
\hline Total & 2 & 5 & 6 & 13 & 6 & 28 & 12 & 46 & 1 & 18 & 19 \\
\hline
\end{tabular}

a Occurred in both the NAs and ROW in either 1991 or 1992 or occurred in both NAs and ROW when both years were combined.

b Plants not identified to species.

c Identified plant species for which an indicator status has not yet been determined. 
TABLE 26 Coefficient of Community Values Comparing 1991 and 1992 Data on the Basis of Species Composition - Forested Wetland Community

\begin{tabular}{llll} 
& \multicolumn{2}{c}{ Comparison } \\
\cline { 2 - 3 } & NAs & & ROW \\
\cline { 2 - 3 } Stratum & 1991 to 1992 & & 1991 to 1992 \\
\hline Herb & 0.37 & 0.13 \\
Shrub & 0.33 & 0.00 \\
Sapling & 0.00 & 0.00 \\
Tree & 0.25 & 0.00 \\
Combined & 0.38 & 0.13 \\
Strata & & \\
\hline
\end{tabular}

a There were no saplings in common in 1991 and 1992. 
TABLE 27 Prevalence Index and Average Wetland Values for All Species and Dominant Species Only in the NAs and the ROW (by individual stratum and combined strata) - Forested Wetland Community

\begin{tabular}{|c|c|c|c|c|c|c|}
\hline \multirow[b]{2}{*}{ Stratum } & \multirow[b]{2}{*}{ Areas } & \multirow[b]{2}{*}{ Species } & \multicolumn{2}{|c|}{$\begin{array}{l}\text { Prevalence } \\
\text { Index Value }\end{array}$} & \multicolumn{2}{|c|}{$\begin{array}{c}\text { Average } \\
\text { Wetland Value }\end{array}$} \\
\hline & & & 1991 & 1992 & 1991 & 1992 \\
\hline \multirow[t]{4}{*}{ Herb } & NAs & AlI & 2.76 & 2.36 & 2.76 & 2.35 \\
\hline & & Dominant only & 2.88 & 2.71 & 2.50 & 2.60 \\
\hline & ROW & All & 2.09 & 1.39 & 2.48 & 1.95 \\
\hline & & Dominant only & 2.00 & 1.00 & 2.00 & 1.00 \\
\hline \multirow[t]{4}{*}{ Shrub } & NAs & All & 4.64 & 4.42 & 3.50 & 2.75 \\
\hline & & Dominant only & 5.00 & 5.00 & 5.00 & 5.00 \\
\hline & Rowa & All & 4.62 & none & 3.50 & none \\
\hline & & Dominant only & 5.00 & none & 5.00 & none \\
\hline \multirow[t]{4}{*}{ Sapling } & $N A s^{b}$ & All & none & 2.75 & none & 3.50 \\
\hline & & Dominant only & none & 2.75 & none & 3.50 \\
\hline & ROWa & All & 3.00 & none & 3.00 & none \\
\hline & & Dominant only & 3.00 & none & 3.00 & none \\
\hline \multirow[t]{3}{*}{ Tree } & NAs & All & 2.87 & 2.32 & 2.50 & 2.25 \\
\hline & & Dominant only & 3.00 & 2.33 & 3.00 & 2.50 \\
\hline & ROWc & & none & none & none & none \\
\hline \multirow{2}{*}{$\begin{array}{l}\text { Combined } \\
\text { Strata }\end{array}$} & NAs & All & $N C^{d}$ & NC & 2.71 & 2.35 \\
\hline & ROW & All & NC & NC & 3.00 & 2.11 \\
\hline
\end{tabular}

a No shrubs or saplings were present on the ROW in 1992.

b No samplings were present in the NAs in 1991.

c No trees were present on the ROW in 1991 or 1992.

d $N C=$ not calculated. Values could not be calculated for combined strata because areal cover (which is not additive) is used in its calculation. 


\section{Discussion}

\subsection{Scrub-Shrub Community}

Prior to construction of the 1991 pipeline, the site was covered with shallow standing water retained by an extensive beaver dam that surrounded the site on the east, south, and west. Construction activities had breached this dam at the west and east edges of the site. However, when we resampled the site in July 1992, the dam had been restored and water levels were comparable to preconstruction levels. The presence of only hydric vegetation on the ROW and the absence of dead or dying upland plants suggest that the dam had been restored prior to the 1992 growing season. The winter survival of the beaver colony indicates that the dam was restored before winter 1991. An abundance of cattails in the ROW in 1992 and scattered cattails in the NAs, along with the absence of cattails in any sampling plots during the 1991 growing season, implies that water levels were low for a sufficient time during the 1991 growing season to allow for cattail establishment. Cattails need very shallow water or saturated soils for germination and survival of seedlings. It is likely that water drawdown associated with breaching of the beaver dam during pipeline construction contributed to seed germination and seedling establishment.

Although the ROW had been cleared of vegetation during pipeline construction, the total areal coverage and number of species present in the herb stratum of the ROW were greater in 1992 than prior to installation of the pipeline in 1991. The areal coverage of herb stratum vegetation, excluding star duckweed and lesser duckweed, was $50.5 \%$ in 1992 compared to $5.6 \%$ in 1991 (prior to pipeline installation). The number of species present doubled. The following factors may have contributed to the rapid development of the herb stratum in the ROW: a period of low water levels during installation of the 1991 pipeline; the presence of partially buried slash on the working side of the ROW, which provided habitat variety; the release of nutrients caused by soil disturbance during construction; and increased light caused by the removal of woody vegetation from the ROW. Also, some of the differences between the June 1991 and the July 1992 sampling results may be related to the later sampling date in 1992.

As in 1991, the transects for sampling in 1992 were located on the basis of a random starting point and thus did not encompass the same plots; this may account for some of the differences in species composition and percent coverages between the two years. Star duckweed was much more abundant in both the ROW and NAs during the 1992 survey than in 1991 . The reason for the increase is not clear, but may be associated with the following: increased winds in the cleared ROW may have blown the surface stratum of lesser duckweed aside, allowing increased light penetration below the water's surface; a plume of nutrients released by pipeline installation activities and the fluctuation of water levels may have contributed to more abundant vegetation; and sampling in 1992 took place later in the growing season.

$\mathrm{CC}_{\mathrm{S}}$ values, comparing the species present by stratum for 1991 and 1992, also reflect changes in the herb stratum in the NAs, which was represented by 20 species in 1991 and 45 species in 1992. Some of the increases in species numbers may be the result of favorable 
conditions for seed germination during pipeline installation caused by the release of nutrients from construction activities and lowering of the water levels. The later sampling date during the 1992 growing season probably also allowed for development of more species.

Comparison of shrub stratum species present in the NAs in 1991 and 1992 resulted in a high $\mathrm{CC}_{\mathrm{s}}(0.86)$. The few differences in species composition are most likely attributable to random sampling. Comparisons of species present in the sapling and tree strata in 1991 and 1992 resulted in lower $\mathrm{CC}_{\mathrm{S}}$ values. Only a few saplings or trees occurred in the NNA and these showed no evidence of disturbance by pipeline installation. Some saplings in the SNA had lodged since the 1991 sampling, but were still alive, as indicated by their foliage.

A high degree of similarity was observed between the 1991 and 1992 PIVs and the 1991 and 1992 AWVs for individual and combined strata. Wetland values for all strata of vegetation in the NAs in 1992 were very similar to corresponding values for 1991 - whether all species or just dominants were considered. The higher PIVs and AWVs for the tree stratum, compared to other strata, were not unique to this study. This same pattern was observed in a number of other ROW studies and may indicate a lower sensitivity of larger plants to hydrologic conditions.

The removal of most woody plants from the ROW and the ensuing increase in emergent vegetation has resulted in an herb stratum on the ROW that includes more species with high fidelity to wetlands. This is reflected in a lower AWV for 1992 than for 1991. Thus, the installation of the pipeline has resulted in both increased species diversity and increased hydric vegetation in the ROW. At the same time, it has created a break in the forest that provides edge habitat for some species, while fragmenting the environment for others. Because the ROW is relatively narrow, it is not likely to impede the dispersal of species, except those that have very limited mobility.

\subsection{Emergent Marsh Community}

Because the natural topography of the emergent marsh site was relatively level and the site was only partially covered by standing water, large differences in the percentage of the soil surface covered by standing water in the NAs could be brought about by small changes in water level. The planned attempt to save and replace the vegetative mat on the surface of the ROW was apparently unsuccessful. While some sections of the mat, measuring up to approximately 1 square meter total area, were returned to the ROW surface, most of the surface consisted of disturbed soils. The intact sections of vegetative mat and the soft saturated soils resulted in a somewhat uneven ROW surface; $39 \%$ was covered with standing water and about $6 \%$ consisted of exposed unvegetated soil. The increase in the percentage of the ROW surface covered with water from 1991 to 1992, compared to the ROW surface in 1991 and compared to the NAs in 1992, may be related to compression of the soils by heavy machinery used for pipeline installation, regrading of the ROW, and vehicle tracks that appear to have been made after final grading.

The number of species occurring in plots in the NAs in 1992 (62) was almost the same as in 1991 (59), with 46 species in common. Some of the differences in species composition may be 
due to the later sampling date in 1992 and some to the limited sampling using randomly located plots. While some changes in species might theoretically be brought about by pipeline installation, it seems reasonable to assume that disturbance was minimal because no evidence of disturbance off of the ROW was noted and hydric conditions were not modified. In 1991, rice cutgrass (Leersia oryzoides) was not recorded in this site. In 1992, it had an average coverage of $3.15 \%$ in the NAs. It is likely that its absence in 1991 is explained by the earlier sampling date when the species was not developed enough to be identified; some of the coverage attributed to grove bluegrass in 1991 may have actually been very immature rice cutgrass. Because grove bluegrass is an early flowering grass, the seed culms that were evident during June 1991 may have already withered by July 8, when the 1992 sampling was conducted.

While the vegetation in the NAs remained very similar to that present prior to pipeline construction, the ROW vegetation was considerably changed by pipeline construction. In 1992, the sum of coverages for all species was much reduced from 1991. The number of species occurring in ROW plots was about $25 \%$ less than the number present in 1991 . Of the 37 species found in ROW plots in 1992, 10 were unique to the newly created ROW - indicating the changed nature of the ROW habitat. The most significant change in the ROW was the lack of competition of shrubs and robust herb species such as cattails, boneset (Eupatorium perfoliatum), and Joe-pyeweed (Eupatoriadelphus maculatus). Minor changes in topography and soil disturbance resulting from pipeline installation activities also contributed to the change in ROW habitat.

It is anticipated that, within several years, the ROW will develop an herb stratum similar to that found in adjacent NAs. However, some differences in species composition are likely to remain, especially if shrubs are not allowed to re-invade the ROW. A lack of shrubs in the ROW will likely exclude some herb species that are typically found only in plots where shrubs, rather than robust emergent herbs, are dominant.

\subsection{Forested Wetland Community}

Only a single, randomly located transect was sampled in the forested wetland community because of the small community size. One transect is not an adequate sample size to accurately assess the ROW impacts. Differences in data could be attributable to plot location (a random sample was taken for each survey). For this community, observable impacts were more reliable than the collected data. In early June 1991, many species were too small to identify or had not yet emerged. The two NAs also have slight topographic differences; the SNA is at a slightly higher elevation.

The ROW through the forested wetland community was altered in a number of ways. Shrubs, saplings, and trees were removed and slash was placed on the working side to support construction equipment. This slash remained partially embedded in surface soils. Also, the ROW surface was generally depressed, as evidenced by the fact that $39 \%$ of the ROW surface was covered with standing water, while no standing water occurred in the NAs. These changes in the ROW surface resulted in blue cattail, which was not present in 1991, becoming the leading 
dominant in 1992. There was no observable evidence of disturbance in the physical habitat of the area. Even though a single transect was sampled, the wetland indicator values (AWVs and PIVs) for the various strata in the NAs were very similar for 1991 and 1992. Wetland indicator values for the herb stratum in the ROW in 1992 were all lower than comparable values for 1991, indicating that more hydric vegetation was present in 1992. 


\section{Summary and Conclusions}

\subsection{Summary}

As stated in the Introduction (Section 1), the primary goal of the GRI Wetland Corridors Program is to identify and evaluate the impacts of pipeline construction and ROW maintenance on the wetlands they traverse. To accomplish this goal, pipelines crossing various wetlands throughout the eastern United States were surveyed. The objectives for each study site are to document the vegetative communities on the ROW and NAs that were not disturbed by pipeline construction; evaluate the similarities and differences between the plant communities on the ROW and the NAs; document qualitative changes to topography, soils, and hydrology attributable to ROW construction; and identify impacts caused by ROW construction on rare, threatened, endangered, or sensitive species.

This study involved the collection and analysis of data within the Mill Creek tributary crossing wetland along the southwest border of Watertown, New York. A gas transmission pipeline was installed approximately 12 months prior to collection of the data presented in this report. Prior to installation of the pipeline in 1991, field studies were conducted at this site to provide data on an existing pipeline installed in 1966 and to provide baseline data for the present study. Three vegetative community types were sampled during this study: a scrub-shrub community, an emergent marsh, and a forested wetland.

The 1991 pipeline was installed within the 1966 pipeline ROW in the scrub-shrub community and forested wetland, but it crossed the emergent marsh within a newly created ROW. In two communities (the scrub-shrub community and the emergent marsh), five transects (comprising a total of 10 sampling plots within the ROW and 10 within the NAs) were established for the 1991 and 1992 surveys. Vegetational data from the randomly located transects for the two years were very similar for the NAs in the emergent marsh. Data for the shrub stratum in the scrub-shrub community for the two years were quite similar, while data for the sapling and tree strata were less similar. The size and number of plots appeared adequate to characterize the hydric qualities of the vegetation; little variation in wetland indicators was observed between the two years. The single transect in the forested wetland, comprising only two plots in the NAs, resulted in low $\mathrm{CC}_{s}$ values when comparing the plants in each stratum during each year. However, the wetland indicator values were again very similar for each stratum present in 1991 and 1992.

Scrub-Shrub Community. In the scrub-shrub community, within 12 to 13 months after pipeline installation, 25 species had become established on the ROW, with about $50 \%$ total areal coverage for emergent species. The floating star duckweed and lesser duckweed were abundant in the standing water. Some of the emergent species were associated with soils elevated by embedded slash used to support heavy equipment during pipeline construction. The only observable changes in the NAs were an increase in the abundance of duckweeds and cattail and the lodging of some saplings in the SNA. The beaver dam had been restored, and water depths were similar to those observed in 1991. 
Emergent Marsh Community. In the emergent marsh community, 36 species had become established on the ROW within the 12-13 months since pipeline installation; the total coverage was only about $25 \%$ despite replacement of the vegetative mats. Comparing the 1992 plant community on the ROW with the community present prior to pipeline construction resulted in a $\mathrm{CC}_{S}$ of 0.65 , indicating considerable similarity in species composition even though fewer species were present. More of the ROW surface was covered by standing water in 1992 than in 1991, although the percentage of the surface covered by standing water in the NAs had decreased. It is anticipated that the ROW community will soon develop into a community similar to the herb stratum observed in portions of the NAs where shrubs are absent.

Forested Wetland Community. One year after pipeline installation, the two plots within the ROW in the forested wetland contained only 21 species, 10 of which were introduced. Total vegetative cover was low; cattail was the leading dominant. The ROW surface was uneven and contained considerable standing water on the storage side of the ROW and partially embedded slash on the working side. No impacts (such as tire tracks, rip-rap, or soil piles) were observable in the NAs.

\subsection{Conclusions}

Considerable revegetation of the ROW had occurred within the one year after pipeline construction, particularly in the scrub-shrub community. No seeding of the ROW surface was completed following pipeline construction. Numerous species from the NAs and naturally occurring seed banks had become established on the ROW in these communities. Total coverage for all species occurring in the ROW was highest in the scrub-shrub community, where standing water was most abundant, and lowest in the forested wetland community, where shade intensity was greatest. The slash embedded in the working side of the ROW provided habitat for several mesic species in both the scrub-shrub and forested wetland communities. The unevenness of the ROW surface in the emergent marsh may have retarded revegetation, but over periods of fluctuating water levels, the effects will most likely be eliminated. Comparison of data for the NAs in 1991 and 1992 indicates that the sample design (using five transects) was adequate to provide a good general description of the vegetation in the herb and shrub strata but was less definitive for the sapling and tree strata. Wetland indicators differed little from year to year for the same stratum in the same area. This was true even for the sapling and tree strata in the NAs, where $\mathrm{CC}_{\mathrm{s}}$ values comparing data from the 1991 and 1992 sampling events were relatively low.

The ROW in each of the three community types continued to exhibit wetland hydrology, soils, and vegetation. If woody vegetation is excluded from the ROW by future maintenance, the differences between the ROW and the NAs will be related to the proportion of woody vegetation present in the NAs. Follow-up studies are needed to determine the rate of succession on the ROW and the nature of the climax (or disclimax) community that will become established there.

While the presence of slash embedded in the substrate on the working side of the ROW in the scrub-shrub community and forested wetland contributed to species diversity, much of that diversity was the result of the slash providing habitat for more mesic species. It is not possible to 
predict the impact of the slash on the future development of plant species in the ROW from a study performed just one year after pipeline construction. 


\section{References}

Bonham, C.P., 1989, Measurements for Terrestrial Vegetation, John Wiley and Sons, New York, N.Y.

Brower, J., J. Zar, and C. von Ende, 1990, Field and Laboratory Methods for General Ecology, Third Edition, Wm. C. Brown Publishers, Dubuque, Iowa.

Cowardin, L.M., et al., 1979, Classification of Wetlands and Deep Water Habitats of the United States, U.S. Fish and Wildlife Service, U.S. Geological Survey, and U.S. National Oceanic and Atmospheric Administration, Washington, D.C.

Federal Interagency Committee for Wetland Delineation, 1989, Federal Manual for Identifying and Delineating Jurisdictional Wetlands, U.S. Army Corps of Engineers, U.S. Environmental Protection Agency, U.S. Fish and Wildlife Service, and U.S. Department of Agriculture, Cooperative Technical Publication, Washington, D.C.

FICWD: see Federal Interagency Committee for Wetland Delineation.

New York State Department of Transportation, 1986, NYS Freshwater Wetlands Map, Jefferson County Map 28 of 40, NYSDT, State Campus, Albany, N.Y. 12226.

NYSDT: see New York State Department of Transportation.

Reed, P.B., Jr., 1988, National List of Plant Species that Occur in Wetlands, Region 1, U.S. Department of the Interior, Biology Report 88 (26.1).

SCS: see Soil Conservation Service.

Soil Conservation Service, 1989, Soil Survey; Jefferson County, New York, U.S. Department of Agriculture, Washington, D.C.

Soil Conservation Service, 1991, Hydric Soils of the United States, U.S. Department of Agriculture, in cooperation with the National Technical Committee for Hydric Soils.

Van Dyke, G.D., L.M. Shem, and R.E. Zimmerman, 1994, Pipeline Corridors through Wetlands - Impacts on Plant Communities: Mill Creek Tributary Crossing, Jefferson County, New York, 1991 Survey, GRI-93/0091, prepared by Argonne National Laboratory, Argonne, Ill, for Gas Research Institute. 
Wright, T., 1991, Harroun Lumber Corporation (located adjacent to the wetland), personal conversation with G.D. Van Dyke, June 13.

Zimmerman, R.E., et al., 1991, Pipeline Corridors through Wetlands - Impacts on Plant and Avian Diversity: Boreal Wetlands, Oconto County, Wisconsin, GRI-91/0046, prepared by Argonne National Laboratory, Argonne, Ill., for the Gas Research Institute, Chicago, Ill. 
Appendix A:

Definition of Jurisdictional Wetlands 


\section{Appendix A: Definition of Jurisdictional Wetlands}

Wetland identification and delineation necessary to implement Section 404 of the Clean Water Act and the "Swampbuster" (Subtitle B) provision of the Food Security Act of 1985 involves four agencies: the U.S. Army Corps of Engineers (COE), the U.S. Environmental Protection Agency (EPA), the U.S. Fish and Wildlife Service (FWS), and the Soil Conservation Service (SCS). On January 10, 1989, these agencies, which had operated with slightly different definitions of wetland, adopted a uniform definition based on hydrology, vegetation, and soils.

The joint agreement stipulates that to be classified as a Jurisdictional Wetland, an area must have hydrotrophytic vegetation, hydric soils, and a wetland hydrology. All three criteria are mandatory; without any one criterion, the area is not a Jurisdictional Wetland. A schematic diagram of this delineation process is shown in Figure A.1. See the Federal Manual for Identifying and Delineating Jurisdictional Wetlands for a more detailed discussion of the various terms and criteria (FICWD 1989).

Problems uncovered during field trials of the 1989 Federal Manual and disagreement among the four agencies on revisions in 1991 resulted in the EPA and the COE reverting to use of the 1987 COE Wetlands Delineation Manual, which also defines wetlands on the basis of vegetation, hydric soils, and hydrology, but with slightly different definitions of these parameters. In January 1994, the four agencies entered into a joint Memorandum of Agreement, "Concerning the Delineation of Wetlands for Purposes of Section 404 of the Clean Water Act and Subtitle B of the Food Security Act," which, in broad terms, stipulates that the EPA and the COE will accept SCS procedures for delineating wetlands (SCS 1988) on agricultural lands and that SCS will use the 1987 COE Wetlands Delineation Manual (COE 1987) for areas that are not agricultural lands.

The individual reports on the pipeline crossings through wetlands that are part of the GRI Wetland Corridors Program use the definition and criteria of the 1989 Federal Manual that were in effect during 1990 and 1991, the first two years of these studies. The use of the rigorous criteria of the 1989 manual should provide sufficient information for application to other procedures in the evolving field regulatory procedures for delineation and preservation of jurisdictional wetlands.

\section{References}

COE: see U.S. Army Corps of Engineers.

Federal Interagency Committee for Wetland Delineation, 1989, Federal Manual for Identifying and Delineating Jurisdictional Wetlands, U.S. Army Corps of Engineers, U.S. Environmental Protection Agency, U.S. Fish and Wildlife Service, and U.S. Department of Agriculture, Cooperative Technical Publication, Washington, D.C.

FICWD: see Federal Interagency Committee for Wetland Delineation. 
SCS: see Soil Conservation Service.

Soil Conservation Service, 1988, National Food Security Act Manual, U.S. Department of Agriculture, Washington, D.C.

U.S. Army Corps of Engineers, 1987, Corps of Engineers Wetlands Delineation Manual, Technical Report Y-87-1, Waterways Experiment Station, Vicksburg, Miss.

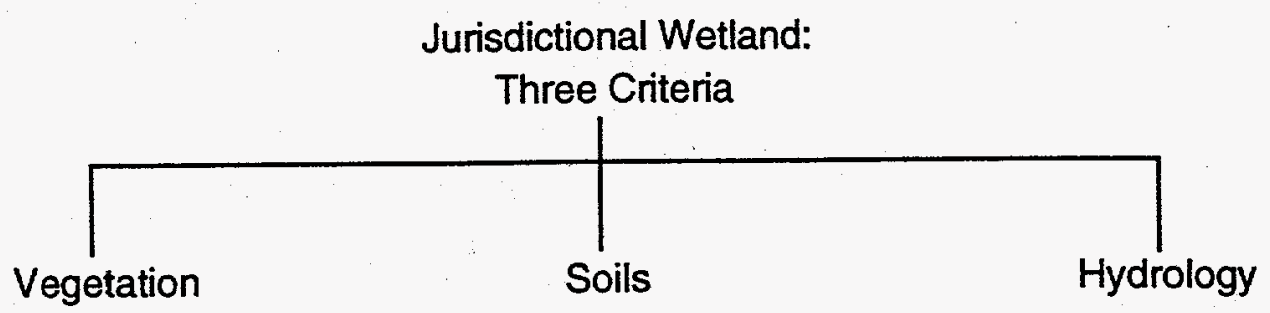

$1.50 \%$ dominant species $\mathrm{OBL}, \mathrm{FACW}$, and/or FAC or

2. Prevalence index $<3.0$

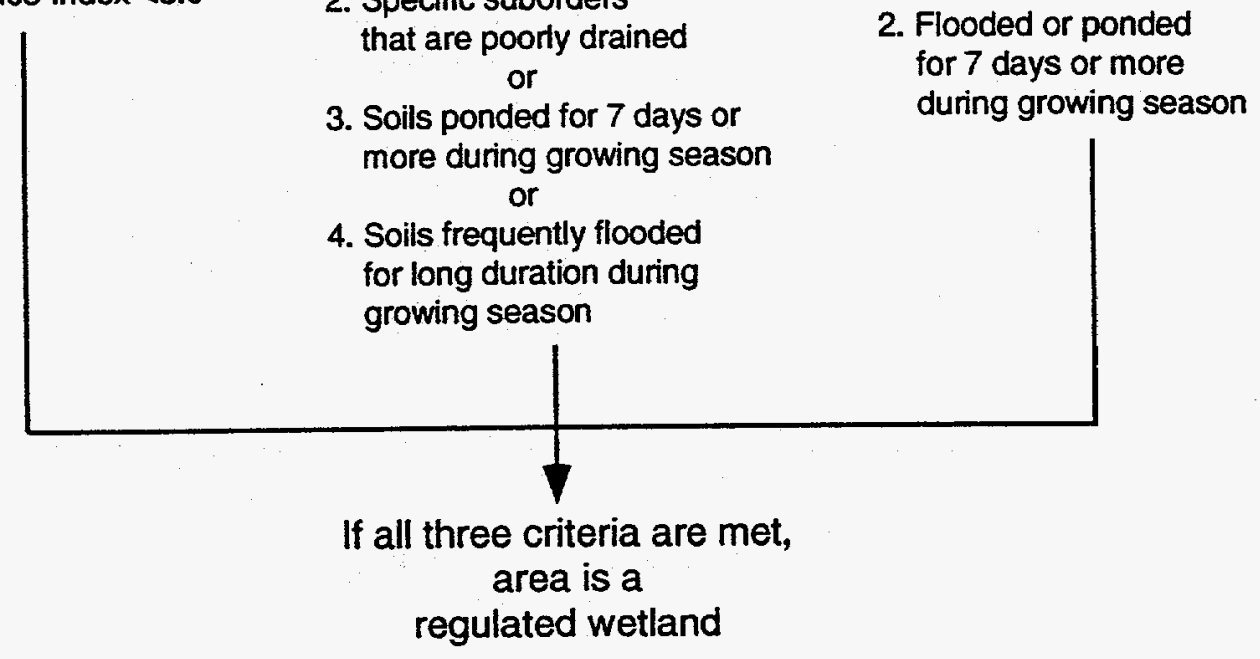

1. Saturated for 7 days or more during growing season

or

1. Histosols

Specific suborders that are poorly drained

Soils ponded for 7 days or growing season

Soils frequently flooded for long duration during growing season

regulated wetland

FIGURE A.1 Schematic Diagram of the Wetland Delineation Process (Source: FICWD 1989) 
Appendix B:

Data Analysis - Definitions and Equations 


\section{Appendix B: Data Analysis - Definitions and Equations}

\section{B.1 Wetland Indicator Categories}

Wetland indicator categories used in this report to classify the types of plant species were taken from Reed (1988). The five basic categories, commonly called the "wetland indicator status," are based on frequency of occurrence in wetlands. They are defined as follows:

\begin{tabular}{lll}
\multicolumn{1}{c}{ Category } & Value & \multicolumn{1}{c}{ Definition } \\
\hline Obligate wetland (OBL) & 1.0 & $\begin{array}{l}\text { Plants that almost always occur in wetlands under } \\
\text { natural conditions (estimated probability }>99 \%)\end{array}$ \\
$\begin{array}{l}\text { Facultative wetland } \\
\text { (FACW) }\end{array}$ & 2.0 & $\begin{array}{l}\text { Plants that usually occur in wetlands (estimated } \\
\text { probability 67-99\%) but occasionally are found in } \\
\text { nonwetlands }\end{array}$ \\
$\begin{array}{l}\text { Facultative (FAC) } \\
\text { Facultative upland }\end{array}$ & 3.0 & $\begin{array}{l}\text { Plants that are equally likely to occur in wetlands or } \\
\text { nonwetlands (estimated probability } 34-66 \%)\end{array}$ \\
(FACU) & 4.0 & $\begin{array}{l}\text { Plants that usually occur in nonwetlands (estimated } \\
\text { probability } 67-99 \%) \text { but occasionally are found in } \\
\text { wetlands (estimated probability 1-33\%) } \\
\text { Obligate upland (UPL) }\end{array}$ \\
\hline 5.0 & $\begin{array}{l}\text { Plants that almost always occur in nonwetlands under } \\
\text { natural conditions (estimated probability }>99 \%)\end{array}$ \\
\hline
\end{tabular}




\section{B.2 Life-Form and Origin}

The life-form and origin symbols are used for describing plant characteristics. The following symbols are used:

\begin{tabular}{ll}
\hline Symbol & Life-Form or Origin \\
\hline A & Annual \\
B & Biennial \\
E & Emergent \\
F & Forb \\
F3 & Fern \\
G & Grass \\
GL & Grasslike \\
H2 & Horsetail \\
I & Introduced \\
N & Native \\
P & Perennial \\
S & Shrub \\
$T$ & Tree \\
V & Herbaceous vine \\
WV & Woody vine \\
\hline
\end{tabular}

Symbols are combined to describe the life-form and origin; for example, ANG means annual native grass and PIEF means perennial introduced emergent forb. For further description refer to the report by Reed (1988).

\section{B.3 Prevalence Index Value}

The prevalence index value (PIV) was determined by using the method outlined in the 1989 Federal Manual (FICWD 1989). The PIV, modified for this report to use relative percent areal coverage instead of relative frequencies as described in the 1989. Federal Manual, is defined as

$$
P I V=\frac{R P C_{o}+2 R P C_{f w}+3 R P C_{f}+4 R P C_{f u}+5 R P C_{u}}{100}
$$

where

$$
\begin{aligned}
\mathrm{RPC}_{\mathrm{o}} & =\text { Relative percent coverage (RPC) of obligate wetland species, } \\
\mathrm{RPC}_{\mathrm{fw}} & =\mathrm{RPC} \text { of facultative wetland species, }
\end{aligned}
$$




$$
\begin{aligned}
\mathrm{RPC}_{\mathrm{f}} & =\mathrm{RPC} \text { of facultative species, } \\
\mathrm{RPC}_{\mathrm{fu}} & =\mathrm{RPC} \text { of facultative upland species, and } \\
\mathrm{RPC}_{\mathrm{u}} & =\mathrm{RPC} \text { of upland species. }
\end{aligned}
$$

\section{B.4 Average Wetland Value}

The average wetland value (AWV), defined in Zimmerman et al. (1991), differs from the PIV in that it is not coverage data or frequency of occurrence that is used in determining the AWV, but rather the total number of species present. Thus, all species present are represented equally in the AWV. The AWV is defined as

$$
A W V=\frac{N_{o}+2 N_{f w}+3 N_{f}+4 N_{f u}+5 N_{u}}{N_{o}+N_{f w}+N_{f}+N_{f u}+N_{u}}
$$

where

$$
\begin{aligned}
N_{0} & =\text { number of obligate wetland species, } \\
N_{f w} & =\text { number of facultative wetland species, } \\
N_{f} & =\text { number of facultative species, } \\
N_{f u} & =\text { number of facultative upland species, and } \\
N_{u} & =\text { number of upland species. }
\end{aligned}
$$

\section{B.5 References}

Federal Interagency Committee for Wetland Delineation, 1989, Federal Manual for Identifying and Delineating Jurisdictional Wetlands, U.S. Army Corps of Engineers, U.S. Environmental Protection Agency, U.S. Fish and Wildlife Service, and U.S. Department of Agriculture, Cooperative Technical Publication, Washington, D.C.

FICWD: see Federal Interagency Committee for Wetland Delineation. 
Reed, P.B., Jr., 1988, National List of Plant Species that Occur in Wetlands, Region I, U.S. Department of the Interior, Biology Report 88 (26.1).

Zimmerman, R.E., et al., 1991, Pipeline Corridors through Wetlands - Impacts on Plant and Avian Diversity: Boreal Wetlands, Oconto County, Wisconsin, GRI-91/0046, prepared by Argonne National Laboratory, Argonne, Ill., for the Gas Research Institute, Chicago, Ill. 
Appendix C:

Plant Species List, Areal Coverage Data, and Species Distribution 


\section{Appendix C: Plant Species List, Areal Coverage Data, and Species Distribution}

TABLE C.1 Plant Species List - Scrub-Shrub Community

\begin{tabular}{|c|c|c|c|c|}
\hline $\begin{array}{l}\text { Field } \\
\text { Number }\end{array}$ & $\begin{array}{c}\text { Species Scientific Name and } \\
\text { Authority }\end{array}$ & Common Name & $\begin{array}{l}\text { Region } 1 \\
\text { Wetland } \\
\text { Indicator } \\
\text { Category }\end{array}$ & $\begin{array}{l}\text { Life- } \\
\text { Form/ } \\
\text { Origin }^{b}\end{array}$ \\
\hline 41 & Acer rubrum $\mathrm{L}$. & Red maple & FAC & NT \\
\hline 42 & Acer saccharinum $\mathrm{L}$. & Silver maple & FACW & NT \\
\hline 1 & Alisma plantago-aquatica $\mathrm{L}$. & Broad-leaf water plantain & OBL & PNEF \\
\hline 375 & Ambrosia artemisiifolia $L$. & Annual ragweed & FACU & ANF \\
\hline 76 & Bidens cernua $\mathrm{L}$. & Nodding beggar's-ticks & OBL & AlF \\
\hline 331 & Bidens frondosa $\mathrm{L}$. & Devil's beggar-ticks & FACW & ANF \\
\hline 342 & $\begin{array}{l}\text { Calamagrostis canadensis (Michx.) } \\
\text { Beauv. }\end{array}$ & Blue-joint reedgrass & FACW+ & PNG \\
\hline 305 & $\begin{array}{l}\text { Carex bebbii (L.H. Bailey) Olney ex } \\
\text { Fernald }\end{array}$ & Bebb's sedge & $\mathrm{OBL}$ & PNGL \\
\hline 301 & Carex normalis Mackenz & Larger straw sedge & FACU & PNGL \\
\hline 331 & Carex spp. & & & \\
\hline 346 & Ceratophyllum demersum L. & Common hornwort & OBL & PN/F \\
\hline 224 & Circaea lutetiana L. & $\begin{array}{l}\text { Southern broad-leaf } \\
\text { enchanter's nightshade }\end{array}$ & FACU & PNF \\
\hline 6 & Cornus amomum Mill. & Silky dogwood & FACW & NS \\
\hline 90 & Cornus foemina Mill. & Stiff dogwood & FAC & NS \\
\hline 5 & Cornus stolonifera Michx. & Red-osier dogwood & FACW+ & NS \\
\hline 300 & $\begin{array}{l}\text { Eleocharis obtusa (Willd.) } \\
\text { J.A. Schultes }\end{array}$ & Blunt spikerush & OBL & APNEGL \\
\hline 347 & Erigeron annuus (L.) Pers. & White-top fleabane & FACU & ANF \\
\hline 27 & Eupatorium perfoliatum L. & Common boneset & FACW+ & PNF \\
\hline 348 & Fragaria virginiana Duchesne & Virginia strawberry & FACU & PNF \\
\hline 349 & Fraxinus nigra Marshall & Black ash & OBL & NETS \\
\hline 38 & Fraxinus pennsy/vanica Marshall & Green ash & FACW & NT \\
\hline 302 & Galium palustre L. & Marsh bedstraw & $\mathrm{OBL}$ & PNF \\
\hline 309 & Glyceria striata (Lam.) A. Hitchc. & Fowl manna grass & $\mathrm{OBL}$ & PNEG \\
\hline 111 & Impatiens capensis Meerb. & Spotted touch-me-not & FACW & ANF \\
\hline 327 & Juncus canadensis J.Gay & Canada rush & $\mathrm{OBL}$ & PNGL \\
\hline 365 & Juncus tenuis Willd. & Slender rush & FAC- & PNGL \\
\hline 374 & Lemna minor L. & Lesser duckweed & $\mathrm{OBL}$ & $\mathrm{PN} / \mathrm{F}$ \\
\hline 373 & Lemna trisulca $\mathrm{L}$. & Star duckweed & $O B L$ & PN/F \\
\hline 72 & Ludwegia palustris (L.) Elliott & Marsh seedbox & OBL & PNEF \\
\hline 77 & $\begin{array}{l}\text { Lycopus americanus Muhl. ex } \\
\text { W. Barton }\end{array}$ & American bugleweed & OBL & PNF \\
\hline 74 & Lysimachia thyrsiflora L. & Tufted loosestrife & $\mathrm{OBL}$ & PIF \\
\hline 372 & Mimulus ringens $\mathrm{L}$. & Alleghany monkey-flower & OBL & PNF \\
\hline 374 & Pilea pumila (L.) Gray & Canada clearweed & FACW & ANF \\
\hline 379 & Plantago rugelii Decne. & Black-seed plantain & FACU & PNF \\
\hline
\end{tabular}


TABLE C.1 (Cont.)

\begin{tabular}{|c|c|c|c|c|}
\hline $\begin{array}{l}\text { Field } \\
\text { Number }\end{array}$ & $\begin{array}{c}\text { Species Scientific Name and } \\
\text { Authority }\end{array}$ & Common Name & $\begin{array}{l}\text { Region } 1 \\
\text { Wetland } \\
\text { Indicator } \\
\text { Category }\end{array}$ & $\begin{array}{l}\text { Life- } \\
\text { Form/ } \\
\text { Origin }\end{array}$ \\
\hline 328 & Poa pratensis $\mathrm{L}$. & Kentucky bluegrass & FACU & PNG \\
\hline 37 & Polygonum amphibium L. & Water smartweed & OBL & PNE/F \\
\hline 353 & Polygonum pensylvanicum L. & Pennsylvania smartweed & FACW & ANEF \\
\hline 337 & Potentilla norvegica L. & Norwegian cínquefoil & FACU & ABPNF \\
\hline 324 & Potamogeton pectinatus $\mathrm{L}$. & Sago pondweed & OBL & PNEF \\
\hline 338 & Rorripa spp. & & & \\
\hline 332 & Rumex spp. & & & \\
\hline 106 & Salix bebbiana Sarg. & Bebb willow & FACW & NS \\
\hline 39 & Salix discolor Muhl. & Pussy willow & FACW & NS \\
\hline 306 & Salix fragilis $\mathrm{L}$. & Crack willow & FAC & IT \\
\hline 71 & Salix petiolaris Pursh & Meadow willow & OBL & NS \\
\hline 304 & Sium suave Walter & Hemlock water-parsnip & $O B L$ & PNEF \\
\hline 51 & Solanum dulcamara $L$. & Climbing nightshade & FAC- & PIF \\
\hline 369 & Sparganium spp. & & & \\
\hline 339 & Taraxacum officinale G.H. Weber & Common dandelion & FACU- & PIF \\
\hline 343 & Trifolium repens $\mathrm{L}$. & White clover & FACU- & PIF \\
\hline 112 & Typha $\times$ glauca Godr. & Blue cattail & OBL & PNEF \\
\hline 33 & Ulmus americana $\mathrm{L}$. & American elm & FACW- & NT \\
\hline 378 & Urtica dioica $\mathrm{L}$. & Stinging nettle & FACU & PIF \\
\hline 109 & Verbena hastata $\mathrm{L}$. & Blue vervain & FACW+ & PNF \\
\hline 55 & Vicia cracca L. & Cow-vetch & UPL & PIF \\
\hline
\end{tabular}

a Wetland indicator categories are assigned to plants in the United States on a regional basis. New York is in Region 1. See Appendix B for more detailed information on wetland indicator categories. A " + " following an indicator reveals a frequency toward the high end of the category (more frequently found in wetlands), while a "-" indicates a frequency toward the low end (less frequently found in wetlands).

b Plant characteristics and life-forms assigned to each species, as indicated in this column, are explained in Reed (1988). (See Appendix B, Section B.2, for definitions of life-forms and origins.) 
TABLE C.2 Percent Areal Coverage Estimates by Stratum for Plant Species in the Scrub-Shrub Community

\begin{tabular}{|c|c|c|c|c|c|c|c|c|c|c|c|c|c|c|c|c|c|c|c|c|c|}
\hline \multirow{2}{*}{$\begin{array}{c}\text { Field } \\
\text { Number }\end{array}$} & \multirow[b]{2}{*}{ Species Scientific Name } & \multicolumn{5}{|c|}{ NNA } & \multicolumn{5}{|c|}{ North ROW } & \multicolumn{5}{|c|}{ South ROW } & \multicolumn{5}{|c|}{ SNA } \\
\hline & & $\mathrm{T} 1$ & $\mathrm{~T} 2$ & T3 & T4 & T5 & $\mathrm{T} 1$ & $\mathrm{~T} 2$ & T3 & T4 & T5 & T1 & T2 & T3 & T4 & T5 & $\mathrm{T1}$ & $\mathrm{T} 2$ & T3 & $\mathrm{T} 4$ & T5 \\
\hline \multicolumn{2}{|c|}{ Standing water } & 99 & 98 & 98 & 98 & 99 & 100 & 100 & 100 & 100 & 100 & 95 & 98 & 98 & 99 & 80 & 98 & 98 & 98 & 98 & 85 \\
\hline \multicolumn{22}{|c|}{ Herb stratum } \\
\hline 41 & Acer rubrum & - & - & $\cdot$ & - & - & - & - & - & - & - & 0.5 & - & $\cdot$ & - & $\cdot$ & 0.5 & - & - & $\cdot$ & - \\
\hline 42 & Acer saccharinum & 1 & 0.5 & 1. & - & 0.5 & - & - & - & - & - & - & - & 2 & - & 0.5 & - & - & - & 0.5 & - \\
\hline 1 & Alisma plantago-aquatica & - & 0.5 & - & 0.5 & - & 1 & 1 & 0.5 & 10 & 2 & 2 & 15 & 5 & 40 & 10 & 0.5 & 0.5 & 0.5 & 0.5 & 0.5 \\
\hline 375 & Ambrosia artemisiifolia & - & - & - & - & - & - & - & - & - & - & - & - & - & - & $\cdot$ & 0.5 & $\cdot$ & - & - & - \\
\hline 76 & Bidens cernua & - & - & - & - & - & - & - & 0.5 & - & - & 0.5 & - & - & - & 0.5 & - & - & - & - & - \\
\hline 331 & Bidens frondosa & - & - & - & $\cdot$ & - & - & - & - & - & - & - & - & - & - & 0.5 & - & - & - & 0.5 & - \\
\hline 342 & Calamagrostis canadensis & - & - & - & $\cdot$ & - & - & - & - & - & - & - & - & - & - & - & - & - & 0.5 & - & - \\
\hline 305 & Carex bebbii & - & - & - & - & - & - & - & - & - & - & - & - & - & - & - & - & - & 0.5 & - & 0.5 \\
\hline 301 & Carex normalis & - & - & - & - & - & - & - & - & - & - & - & - & - & - & - & 0.5 & 0.5 & - & - & - \\
\hline 331 & Carex spp. & - & - & - & - & - & - & - & - & - & - & - & - & 0.5 & - & 0.5 & 1 & 0.5 & - & 0.5 & - \\
\hline 346 & Ceratophyllum demersum & - & - & - & - & - & - & - & - & - & 0.5 & - & - & - & $=$ & - & - & - & - & - & - \\
\hline 224 & Circaea lutetiana & - & - & - & - & - & - & - & 0.5 & - & - & 0.5 & - & - & - & 0.5 & - & - & - & - & - \\
\hline 6 & Cornus amomum & - & - & - & - & - & - & - & - & - & - & - & - & - & - & - & 0.5 & 0.5 & - & - & - \\
\hline 90 & Cornus foemina & 10 & 0.5 & - & 0.5 & - & - & $\cdot$ & - & - & - & - & - & - & - & - & - & - & - & - & - \\
\hline 5 & Cornus stolonifera & - & 0.5 & 1 & 1 & - & - & - & - & - & - & - & $\cdot$ & - & - & - & - & - & - & - & - \\
\hline 300 & Eleocharis obtusa & - & - & - & - & - & : & - & - & - & - & - & 0.5 & - & - & - & - & - & - & - & - \\
\hline 347 & Erigeron annuus & - & - & - & - & - & - & - & - & - & - & - & - & - & - & - & - & - & 0.5 & - & - \\
\hline 27 & Eupatorium perfoliatum & - & - & - & - & - & - & - & - & - & - & - & $\cdot$ & - & 0.5 & - & 0.5 & 0.5 & - & - & - \\
\hline 348 & Fragaria virginiana & - & - & - & - & - & - & - & - & - & - & $\cdot$ & - & - & - & - & - & 0.5 & - & - & - \\
\hline 349 & Fraxinus nigra & - & - & 1 & - & - & - & - & - & - & - & $\cdot$ & - & - & - & - & $\cdot$ & - & - & - & - \\
\hline 38 & Fraxinus pennsylvanica & 1 & 0.5 & 1 & 0.5 & 0.5 & - & - & - & 0.5 & - & 0.5 & - & - & - & - & 0.5 & - & - & $\cdot$ & - \\
\hline 302 & Galium palustre & - & $\cdot$ & - & - & $\cdot$ & - & - & - & - & - & - & - & - & - & - & 0.5 & 0.5 & 0.5 & 0.5 & 0.5 \\
\hline 09 & Glyceria striata & - & - & - & - & - & - & - & - & - & - & $\cdot$ & - & - & 0.5 & 0.5 & $\cdot$ & 0.5 & 0.5 & 0.5 & 0.5 \\
\hline 111 & Impatiens capensis & - & - & - & - & - & - & - & - & - & - & - & - & - & - & 0.5 & 0.5 & - & 0.5 & 0.5 & 0.5 \\
\hline 327 & Juncus canadensis & - & - & - & - & - & - & - & - & - & - & - & - & - & - & - & 0.5 & - & - & - & - \\
\hline 365 & Juncus tenuis & - & - & - & - & - & - & - & - & - & - & - & 0.5 & - & 0.5 & 0.5 & - & - & - & - & - \\
\hline 374 & Lemna minor & 25 & 85 & 60 & 40 & 40 & 40 & 15 & 5 & 2 & 10 & 30 & 25 & 5 & 30 & 10 & 80 & 25 & 50 & 90 & 80 \\
\hline 373 & Lemna trisulca & 70 & 90 & 80 & 55 & 85 & 20 & 25 & 1 & 5 & 30 & 35 & 25 & 1 & 50 & 40 & 75 & 25 & 50 & 90 & 25 \\
\hline 72 & Ludwegia palustris & - & - & - & - & $\cdot$ & 0.5 & - & - & - & - & 0.5 & 0.5 & - & - & - & 0.5 & $\cdot$ & 0.5 & - & 0.5 \\
\hline 77 & Lycopus americanus & - & - & - & - & - & - & - & - & - & - & - & $\cdot$ & - & - & - & 0.5 & 0.5 & 0.5 & 0.5 & 0.5 \\
\hline 74 & Lysimachia thyrsiflora & - & - & - & - & - & - & - & - & - & - & - & - & - & - & - & 0.5 & 0.5 & - & - & - \\
\hline 372 & Mimulus ringens & - & - & - & - & - & - & - & - & - & - & - & - & - & - & - & 0.5 & - & - & - & 0.5 \\
\hline 374 & Pilea pumila & - & - & - & - & - & - & - & - & - & - & - & - & - & - & - & 0.5 & 0.5 & - & - & 0.5 \\
\hline 379 & Plantago rugelii & - & - & - & - & - & - & - & - & - & - & - & - & - & - & - & 0.5 & 0.5 & 0.5 & - & - \\
\hline 328 & Poa pratensis & - & - & $\cdot$ & - & - & - & - & - & - & - & - & - & - & - & 0.5 & - & - & - & - & - \\
\hline
\end{tabular}




\begin{tabular}{|c|c|c|c|c|c|c|c|c|c|c|c|c|c|c|c|c|c|c|c|c|c|}
\hline \multirow{2}{*}{$\begin{array}{l}\text { Field } \\
\text { Number }\end{array}$} & \multirow[b]{2}{*}{ Species Scientific Name } & \multicolumn{5}{|c|}{ NNA } & \multicolumn{5}{|c|}{ North ROW } & \multicolumn{5}{|c|}{ South ROW } & \multicolumn{5}{|c|}{ SNA } \\
\hline & & T1 & T2 & T3 & T4 & T5 & $\mathrm{T1}$ & T2 & T3 & T4 & T5 & T1 & $\mathrm{T} 2$ & T3 & T4 & T5 & T1 & $\mathrm{T} 2$ & T3 & T4 & T5 \\
\hline 37 & Polygonum amphibium & 0.5 & 3 & 5 & 1 & 2 & - & 1 & 0.5 & 0.5 & 0.5 & 0.5 & 0.5 & 0.5 & 0.5 & - & 0.5 & 0.5 & - & 0.5 & 0.5 \\
\hline 353 & Polygonum pensylvanicum & - & - & - & - & - & - & - & - & - & - & - & $\cdot$ & - & - & - & - & - & 0.5 & - & - \\
\hline 337 & Potentilla norvegica & - & - & - & - & - & - & - & - & - & - & - & - & - & - & - & - & - & 0.5 & - & 0.5 \\
\hline 324 & Potamogeton pectinatus & - & - & - & - & - & - & 0.5 & - & 1 & - & - & - & - & 1 & - & - & - & - & - & - \\
\hline 338 & Rorripa spp. & - & - & - & - & - & - & - & - & - & - & - & - & - & - & - & - & - & 0.5 & - & 0.5 \\
\hline 332 & Rumex spp. & - & - & - & - & - & - & - & - & - & - & - & - & - & - & - & 0.5 & - & - & - & - \\
\hline 71 & Salix petiolaris & 2 & - & - & - & 0.5 & - & - & - & - & - & - & - & - & - & - & - & - & - & - & - \\
\hline 304 & Sium suave & 0.5 & - & - & 0.5 & - & 0.5 & 0.5 & 0.5 & - & 0.5 & 0.5 & 0.5 & - & - & 2 & 0.5 & 0.5 & 0.5 & 0.5 & 0.5 \\
\hline 51 & Solanum dulcamara & - & - & - & - & - & - & - & - & - & - & - & - & - & - & - & 0.5 & 0.5 & 1 & - & 0.5 \\
\hline 369 & Sparganium sp. & 2 & - & - & 0.5 & 0.5 & - & 20 & 2 & 0.5 & 40 & 10 & 20 & 20 & 10 & 25 & 0.5 & 0.5 & - & 0.5 & 0.5 \\
\hline 339 & Taraxacum officinale & - & - & - & - & - & - & - & 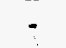 & - & - & - & - & - & - & - & 0.5 & - & - & - & - \\
\hline 343 & Trifolium repens & - & - & - & - & - & - & - & : & - & - & - & - & - & - & - & 0.5 & 0.5 & - & - & - \\
\hline 112 & Typha $\times$ glauca & 5 & 0.5 & 0.5 & 0.5 & - & 50 & 40 & 3 & 0.5 & 30 & 40 & 20 & 15 & 20 & 25 & 1 & 0.5 & - & 0.5 & 3 \\
\hline 33 & Uimus americana & 1 & 0.5 & - & - & - & - & - & - & - & - & - & - & - & - & 0.5 & - & - & - & - & - \\
\hline 378 & Urtica dioica & - & - & - & - & - & - & - & - & - & - & - & - & - & - & $\cdot$ & - & 0.5 & 0.5 & - & 1 \\
\hline 109 & Verbena hastata & - & - & - & - & - & - & - & - & - & - & - & - & - & - & - & - & 0.5 & 0.5 & - & - \\
\hline 55 & Vicia cracca & - & - & - & - & - & - & - & - & - & - & - & - & - & - & - & 0.5 & - & 0.5 & - & 0.5 \\
\hline \multicolumn{22}{|c|}{ Shrub stratum } \\
\hline 41 & Acer rubrum & 1 & - & - & . & - & - & - & - & - & - & - & - & - & - & . & - & - & - & - & - \\
\hline 42 & Acer saccharinum & 2 & 5 & 5 & 3 & 1 & - & - & - & 5 & - & - & - & - & - & - & 10 & 5 & - & 2 & 2 \\
\hline 5 & Cornus stolonifera & - & 2 & - & - & 3 & - & - & - & - & - & - & - & - & - & - & - & - & - & $\cdot$ & - \\
\hline 38 & Fraxinus pennsylvanica & 5 & 2 & 5 & 2 & 3 & - & 2 & - & 2 & - & - & - & - & - & - & 1 & - & - & - & 1 \\
\hline 106 & Salix bebbiana & 1 & - & 2 & - & - & - & - & - & - & - & - & - & - & - & - & - & - & - & - & - \\
\hline 39 & Salix discolor & 5 & 5 & 20 & 3 & - & - & - & - & - & - & - & - & - & - & - & - & - & - & - & $\cdot$ \\
\hline 306 & Salix fragilis & - & 5 & 20 & - & 0.5 & - & - & - & - & - & - & - & - & - & - & - & - & - & - & - \\
\hline 71 & Salix petiolaris & 25 & 50 & 15 & 10 & - & - & - & - & 2 & - & $=$ & - & $\cdot$ & - & - & - & - & - & - & $\cdot$ \\
\hline 33 & Ulmus americana & - & - & 0.5 & - & - & - & - & - & - & - & - & - & - & - & - & 1 & - & - & 0.5 & 1 \\
\hline \multicolumn{22}{|c|}{ Sapling stratum } \\
\hline 42 & Acer saccharinum & - & - & - & 20 & 20 & - & - & - & - & - & - & - & - & - & - & 50 & 20 & 40 & 5 & 2 \\
\hline 38 & Fraxinus pennsylvanica & - & - & - & 1 & 20 & - & - & - & - & - & - & - & - & - & - & 5 & - & 2 & 1 & - \\
\hline 330 & Salix fragilis & - & - & - & - & - & - & - & - & - & - & - & - & - & - & - & - & 10 & - & - & - \\
\hline \multicolumn{22}{|c|}{ Tree stratum } \\
\hline 42 & Acer saccharinum & - & - & - & 1 & 1 & - & - & - & - & - & - & - & - & - & - & 5 & - & 2 & - & 40 \\
\hline 38 & Fraxinus pennsylvanica & - & - & - & - & 1 & - & - & - & - & - & - & - & - & - & - & - & - & - & $\cdot$ & - \\
\hline 304 & Salix fragilis & - & - & 1 & - & . & - & - & - & - & - & - & - & - & - & - & 50 & - & 20 & 10 & 40 \\
\hline
\end{tabular}


TABLE C.3 Average Percent Coverage, Absolute Frequencies, and Distribution by Stratum for Plant Species in the Scrub-Shrub Community

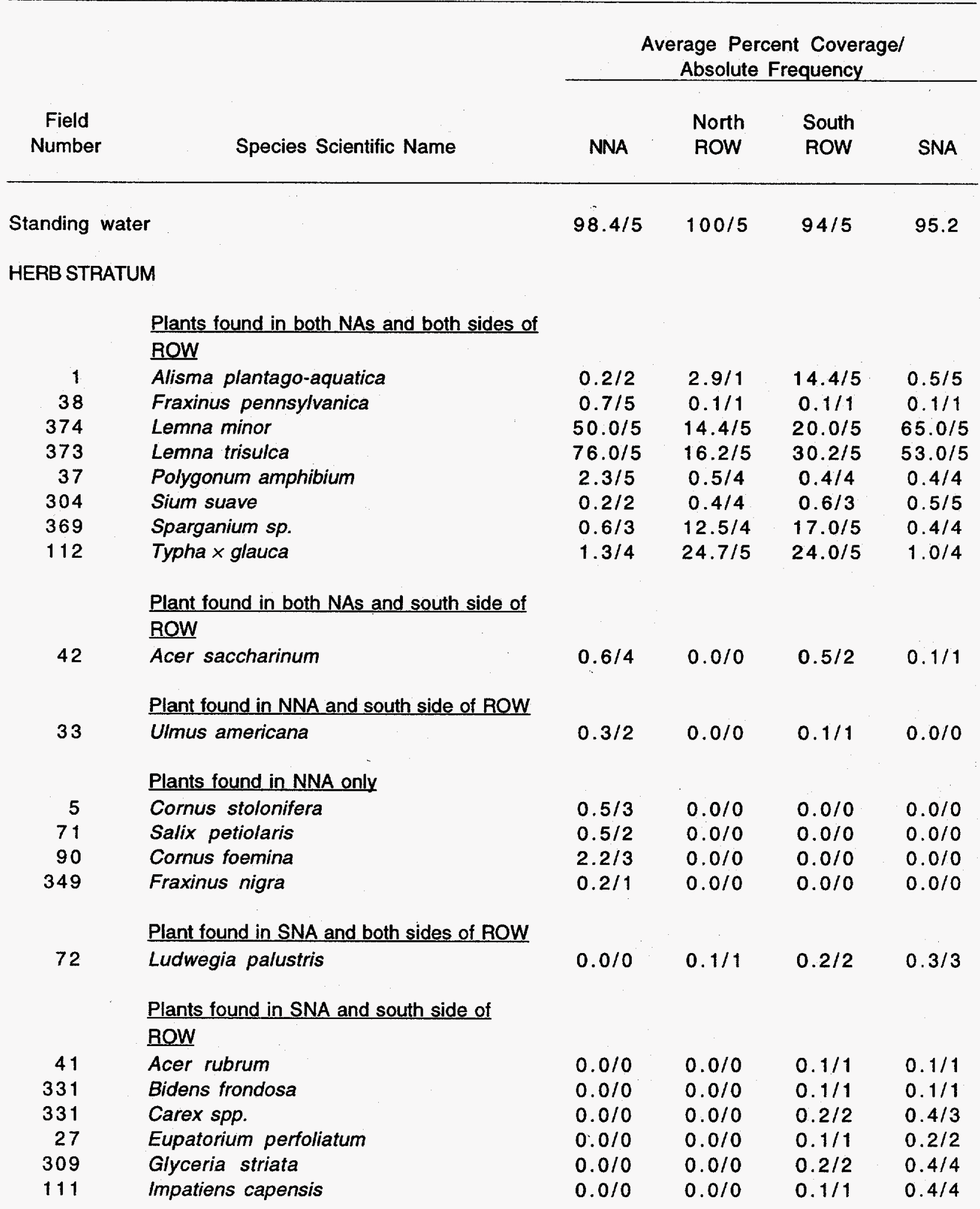


TABLE C. 3 (Cont.)

\begin{tabular}{|c|c|c|c|c|c|}
\hline \multirow[b]{2}{*}{$\begin{array}{l}\text { Field } \\
\text { Number }\end{array}$} & \multirow[b]{2}{*}{ Species Scientific Name } & \multicolumn{4}{|c|}{$\begin{array}{c}\text { Average Percent Coverage/ } \\
\text { Absolute Frequency }\end{array}$} \\
\hline & & NNA & $\begin{array}{l}\text { North } \\
\text { ROW }\end{array}$ & $\begin{array}{l}\text { South } \\
\text { ROW }\end{array}$ & SNA \\
\hline & Plants found in SNA only & & & & \\
\hline 375 & Ambrosia artemisiifolia & $0.0 / 0$ & $0.0 / 0$ & $0.0 / 0$ & $0.1 / 1$ \\
\hline 342 & Calamagrostis canadensis & 0.010 & $0.0 / 0$ & $0.0 / 0$ & $0.1 / 1$ \\
\hline 305 & Carex bebbii & $0.0 / 0$ & $0.0 / 0$ & $0.0 / 0$ & $0.2 / 2$ \\
\hline 301 & Carex normalis & $0.0 / 0$ & $0.0 / 0$ & $0.0 / 0$ & $0.2 / 2$ \\
\hline 6 & Cornus amomum & $0.0 / 0$ & $0.0 / 0$ & $0.0 / 0$ & $0.2 / 2$ \\
\hline 347 & Erigeron annuus & $0.0 / 0$ & $0.0 / 0$ & $0.0 / 0$ & $0.1 / 1$ \\
\hline 348 & Fragaria virginiana & $0.0 / 0$ & $0.0 / 0$ & $0.0 / 0$ & $0.1 / 1$ \\
\hline 302 & Galium palustre & $0.0 / 0$ & $0.0 / 0$ & $0.0 / 0$ & $0.5 / 5$ \\
\hline 327 & Juncus canadensis & $0.0 / 0$ & $0.0 / 0$ & $0.0 / 0$ & $0.1 / 1$ \\
\hline 77 & Lycopus americanus & $0.0 / 0$ & $0.0 / 0$ & $0.0 / 0$ & $0.5 / 5$ \\
\hline 74 & Lysimachia thyrsiflora & $0.0 / 0$ & $0.0 / 0$ & $0.0 / 0$ & $0.2 / 2$ \\
\hline 372 & Mimulus ringens & $0.0 / 0$ & $0.0 / 0$ & $0.0 / 0$ & $0.2 / 2$ \\
\hline 374 & Pilea pumila & $0.0 / 0$ & $0.0 / 0$ & $0.0 / 0$ & $0.3 / 3$ \\
\hline 379 & Plantago rugelii & $0.0 / 0$ & $0.0 / 0$ & $0.0 / 0$ & $0.3 / 3$ \\
\hline 353 & Polygonum pensylvanicum & $0.0 / 0$ & $0.0 / 0$ & $0.0 / 0$ & $0.1 / 1$ \\
\hline 337 & Potentilla norvegica & $0.0 / 0$ & $0.0 / 0$ & $0.0 / 0$ & $0.2 / 2$ \\
\hline 338 & Rorripa sp. & $0.0 / 0$ & $0.0 / 0$ & $0.0 / 0$ & $0.2 / 2$ \\
\hline 332 & Rumex sp. & $0.0 / 0$ & $0.0 / 0$ & $0.0 / 0$ & $0.1 / 1$ \\
\hline 51 & Solanum dulcamara & $0.0 / 0$ & $0.0 / 0$ & $0.0 / 0$ & $0.5 / 4$ \\
\hline 339 & Taraxacum officinale & 0.010 & $0.0 / 0$ & $0.0 / 0$ & $0.1 / 1$ \\
\hline 343 & Trifolium repens & $0.0 / 0$ & $0.0 / 0$ & $0.0 / 0$ & $0.2 / 2$ \\
\hline 378 & Urtica dioica & $0.0 / 0$ & $0.0 / 0$ & $0.0 / 0$ & $0.4 / 3$ \\
\hline 109 & Verbena hastata & $0.0 / 0$ & $0.0 / 0$ & $0.0 / 0$ & $0.2 / 2$ \\
\hline \multirow[t]{2}{*}{55} & Vicia cracca & $0.0 / 0$ & $0.0 / 0$ & $0.0 / 0$ & $0.3 / 3$ \\
\hline & Plants found in both sides of ROW & & & & \\
\hline 76 & Bidens cernua & $0.0 / 0$ & $0.1 / 0$ & $0.2 / 2$ & $0.0 / 0$ \\
\hline 224 & Circaea lutetiana & $0.0 / 0$ & $0.1 / 1$ & $0.2 / 2$ & $0.0 / 0$ \\
\hline \multirow[t]{2}{*}{324} & Potamogeton pectinatus & $0.0 / 0$ & $0.3 / 2$ & $0.2 / 1$ & $0.0 / 0$ \\
\hline & Plant found in north side of ROW only & & & & \\
\hline \multirow[t]{2}{*}{346} & Ceratophyllum demersum & $0.0 / 0$ & $0.1 / 1$ & $0.0 / 0$ & $0.0 / 0$ \\
\hline & Plants found in south side of ROW only & & & & \\
\hline 300 & Eleocharis obtusa & $0.0 / 0$ & $0.0 / 0$ & $0.1 / 1$ & 0.010 \\
\hline 365 & Juncus tenuis & $0.0 / 0$ & $0.0 / 0$ & $0.3 / 3$ & $0.0 / 0$ \\
\hline 328 & Poa pratensis & $0.0 / 0$ & $0.0 / 0$ & $0.1 / 1$ & $0.0 / 0$ \\
\hline
\end{tabular}




\begin{tabular}{|c|c|c|c|c|c|}
\hline \multirow[b]{2}{*}{$\begin{array}{l}\text { Field } \\
\text { Number }\end{array}$} & \multirow[b]{2}{*}{ Species Scientific Name } & \multicolumn{4}{|c|}{$\begin{array}{l}\text { Average Percent Coverage/ } \\
\text { Absolute Frequency }\end{array}$} \\
\hline & & NNA & $\begin{array}{l}\text { North } \\
\text { ROW }\end{array}$ & $\begin{array}{l}\text { South } \\
\text { ROW }\end{array}$ & SNA \\
\hline \multicolumn{6}{|c|}{ SHRUB STRATUM } \\
\hline & $\begin{array}{l}\text { Plants found in both NAs and north side of } \\
\text { ROW }\end{array}$ & & & & \\
\hline 42 & Acer saccharinum & $3.2 / 5$ & $1.0 / 1$ & $0.0 / 0$ & $3.8 / 4$ \\
\hline 38 & $\begin{array}{l}\text { Fraxinus pennsylvanica } \\
\text { Plant found in both NAs only }\end{array}$ & $3.4 / 5$ & $0.8 / 2$ & $0.0 / 0$ & $0.4 / 2$ \\
\hline \multirow[t]{2}{*}{33} & Ulmus americana & $0.1 / 1$ & $0.0 / 0$ & $0.0 / 0$ & $0.5 / 3$ \\
\hline & Plant found in NNA and north side of ROW & & & & \\
\hline 71 & $\begin{array}{l}\text { Salix petiolaris } \\
\text { Plants found in NNA only }\end{array}$ & $20.0 / 4$ & $0.4 / 1$ & $0.0 / 0$ & $0.0 / 0$ \\
\hline 41 & Acer rubrum & $0.2 / 1$ & $0.0 / 0$ & $0.0 / 0$ & $0.0 / 0$ \\
\hline 5 & Cornus stolonifera & $1.0 / 2$ & $0.0 / 0$ & $0.0 / 0$ & $0.0 / 0$ \\
\hline 106 & Salix bebbiana & $0.6 / 2$ & $0.0 / 0$ & $0.0 / 0$ & $0.0 / 0$ \\
\hline 39 & Salix discolor & $6.6 / 4$ & $0.0 / 0$ & $0.0 / 0$ & $0.0 / 0$ \\
\hline 306 & Salix fragilis & $5.1 / 3$ & $0.0 / 0$ & $0.0 / 0$ & $0.0 / 0$ \\
\hline \multicolumn{6}{|c|}{ SAPLING STRATUM } \\
\hline & Plants found in both NAs & & & & \\
\hline 42 & Acer saccharinum & $8.0 / 2$ & $0.0 / 0$ & $0.0 / 0$ & $23.4 / 5$ \\
\hline \multirow[t]{2}{*}{38} & Fraxinus pennsylvanica & $4.2 / 2$ & $0.0 / 0$ & $0.0 / 0$ & $1.6 / 3$ \\
\hline & Plant found in SNA only & - & & & \\
\hline 330 & Salix fragilis & $0.0 / 0$ & $0.0 / 0$ & $0.0 / 0$ & $2.0 / 1$ \\
\hline \multicolumn{6}{|c|}{ TREE STRATUM } \\
\hline & Plants found in both NAs & & & & \\
\hline 42 & Acer saccharinum & $0.4 / 2$ & $0.0 / 0$ & $0.0 / 0$ & $9.4 / 3$ \\
\hline \multirow[t]{2}{*}{304} & Salix fragilis & $0.2 / 1$ & $0.0 / 0$ & $0.0 / 0$ & $24.0 / 4$ \\
\hline & Plant found in NNA only & & & & \\
\hline 38 & Fraxinus pennsylvanica & $0.2 / 1$ & $0.0 / 0$ & $0.0 / 0$ & $0.0 / 0$ \\
\hline
\end{tabular}


TABLE C.4 Plant Species List - Emergent Marsh Community

\begin{tabular}{|c|c|c|c|c|}
\hline $\begin{array}{l}\text { Field } \\
\text { Number }\end{array}$ & $\begin{array}{c}\text { Species Scientific Name } \\
\text { and Authority }\end{array}$ & Common Name & $\begin{array}{l}\text { Region } 1 \\
\text { Wetland } \\
\text { Indicator } \\
\text { Category }\end{array}$ & $\begin{array}{l}\text { Life- } \\
\text { Form/ } \\
\text { Origin }^{b}\end{array}$ \\
\hline 42 & Acer saccharinum $\mathrm{L}$. & Silver maple & FACW & NT \\
\hline 351 & Acorus calamus $\mathrm{L}$. & Sweetflag & OBL & PIEF \\
\hline 361 & Agrostis stolonifera L. & Spreading bentgrass & FACW & PNG \\
\hline 1 & Alisma plantago-aquatica $\mathrm{L}$. & Broad-leaf water plantain & OBL & PNEF \\
\hline 23 & Asclepias incarnata $\mathrm{L}$. & Swamp milkweed & OBL & PNF \\
\hline 76 & Bidens cernua $\mathrm{L}$. & Nodding beggar-ticks. & OBL & AlF \\
\hline 342 & $\begin{array}{l}\text { Calamagrostis canadensis (Michx.) } \\
\text { Beauv. }\end{array}$ & Blue-joint reedgrass & FACW+ & PNG \\
\hline 355 & Calystegia sepium (L.) R.Br. & Hedge bindweed & FAC- & PIF \\
\hline 17 & $\begin{array}{l}\text { Carex bebbii (L.H. Bailey) Olney ex } \\
\text { Fernald }\end{array}$ & Bebb's sedge & OBL & PNGL \\
\hline 367 & Carex comosa Boott & Bearded sedge & OBL & PNEGL \\
\hline 36 & Carex crinita Lam. & Fringed sedge & $O B L$ & PNEGL \\
\hline 82 & Carex flava $\mathrm{L}$. & Yellow sedge & OBL & PNGL \\
\hline 366 & Carex hystericina Muhl. Ex Willd. & Porpucine sedge & $\mathrm{OBL}$ & PNEGL \\
\hline 350 & Carex lasiocarpa Ehrh. & Woolly-fruit sedge & OBL & PNEGL \\
\hline 12 & Carex lupulina Muhl. ex Willd. & Hop sedge & OBL & PNEGL \\
\hline 66 & Carex normalis Mackenz. & Larger straw sedge & FACU & PNGL \\
\hline 91 & Carex pallescens $\mathrm{L}$. & Pale sedge & UPL & PNGL \\
\hline 67 & Carex retrorsa Schweinitz & Retrorse sedge & FACW+ & PNGL \\
\hline 85 & Carex scoparia Schkuhr ex Willd. & Pointed broom sedge & FACW & PNGL \\
\hline 331 & Carex sp. & & & \\
\hline 75 & Carex suberecta (OIney) Britton & Prairie straw sedge & $\mathrm{OBL}$ & PNGL \\
\hline 364 & Carex tenera Dewey & Sparce-flower sedge & $\mathrm{OBL}$ & PNGL \\
\hline 19 & Carex vulpinoidea Michx. & Fox sedge & OBL & PNEGL \\
\hline 7 & Carex $\times$ stipata Muhl. ex Willd. & Stalk-grain sedge & OBL & PNGL \\
\hline 218 & Cicuta bulbifera $\mathrm{L}$. & $\begin{array}{l}\text { Bulblet-bearing } \\
\text { water-hemlock }\end{array}$ & $\mathrm{OBL}$ & PNF \\
\hline 53 & Cicuta maculata L. & Spotted water-hemlock & OBL & PNF \\
\hline 6 & Cornus amomum Mill. & Silky dogwood & FACW & NS \\
\hline 90 & Cornus foemina Mill. & Stiff dogwood & FAC & NS \\
\hline 5 & Cornus stolonifera Michx. & Red-osier dogwood & FACW+ & NS \\
\hline 370 & $\begin{array}{l}\text { Dryopteris spinulosa (O.F. Muell.) } \\
\text { Watt }\end{array}$ & Spinulose woodfern & FAC+ & F3 \\
\hline 333 & Eleocharis sp. & & & \\
\hline 102 & Epilobium hirsutum L. & Great-hairy willow-herb & FACW & PIF \\
\hline 20 & Equisetum arvense $\mathrm{L}$. & Field horsetail & FAC & $\mathrm{PNH} 2$ \\
\hline 62 & Equisetum fluviatile $\mathrm{L}$. & Water horsetail & OBL & $\mathrm{PNH} 2$ \\
\hline 29 & $\begin{array}{l}\text { Eupatoriadelphus maculatus (L.) } \\
\text { R.M. King \& H. Rob. }\end{array}$ & Spotted Joe-pye-weed & FACW & PNF \\
\hline 27 & Eupatorium perfoliatum $\mathrm{L}$. & Common boneset & FACW+ & PNF \\
\hline 43 & Fraxinus pennsylvanica Marshall & Green ash & FACW & NT \\
\hline 61 & Galium palustre $\mathrm{L}$. & Marsh bedstraw & OBL & PNF \\
\hline 325 & Glyceria striata (Lam.) A. Hitchc. & Fowl manna grass & OBL & PNEG \\
\hline
\end{tabular}




\begin{tabular}{|c|c|c|c|c|}
\hline $\begin{array}{l}\text { Field } \\
\text { Number }\end{array}$ & $\begin{array}{c}\text { Species Scientific Name } \\
\text { and Authority }\end{array}$ & Common Name & $\begin{array}{l}\text { Region } 1 \\
\text { Wetland } \\
\text { Indicator } \\
\text { Category }\end{array}$ & $\begin{array}{l}\text { Life- } \\
\text { Form/ } \\
\text { Origin }^{b}\end{array}$ \\
\hline 111 & Impatiens capensis Meerb. & Spotted touch-me-not & FACW & ANF \\
\hline 57 & Iris versicolor $\mathrm{L}$. & Blueflag & $\mathrm{OBL}$ & PNF \\
\hline 84 & Juncus bufonius L. & Toad rush & FACW & ANGL \\
\hline 371 & Juncus canadensis J.Gay & Canada rush & $\mathrm{OBL}$ & PNGL \\
\hline 365 & Juncus tenuis Willd. & Slender rush & FAC- & PNGL \\
\hline 380 & Leersia oryzoides (L.) Swartz & Rice cutgrass & OBL & PNG \\
\hline 333 & Lemna minor L. & Lesser duckweed & OBL & PN/F \\
\hline 373 & Lemna trisulca $\mathrm{L}$. & Star duckweed & OBL & PN/F \\
\hline 98 & Liparis loeselii (L.) L.C. Rich. & Fen orchid & FACW & PNF \\
\hline 335 & Lolium perenne $\mathrm{L}$. & Perennial ryegrass & FACU- & PIG \\
\hline 72 & Ludwegia palustris (L.) Elliott & Marsh seedbox & OBL & PNEF \\
\hline 77 & $\begin{array}{l}\text { Lycopus americanus Muhl. ex } \\
\text { W. Barton }\end{array}$ & American bugleweed & $\mathrm{OBL}$ & PNF \\
\hline 93 & Lycopus uniflorus Michx. & Northern bugleweed & $\mathrm{OBL}$ & PNF \\
\hline 26 & Lysimachia nummularia L. & Creeping jennie & $\mathrm{OBL}$ & PIF \\
\hline 74 & Lysimachia thyrsiflora L. & Tufted loosestrife & OBL & PIF \\
\hline 101 & Mentha spp. & & & \\
\hline 97 & $\begin{array}{l}\text { Nasturtium officinale R. Br. in } \\
\text { W.T. Ait. }\end{array}$ & True water-cress & OBL & PIZEF \\
\hline 8 & Onoclea sensibilis $\mathrm{L}$. & Sensitive fern & FACW & PNEF3 \\
\hline 363 & Oxalis europaea Jordon & Upright yellow woodsorrel & UPL & PIF \\
\hline 362 & Phleum pratensis $\mathrm{L}$. & Timothy & FACU & PIG \\
\hline 368 & Poa palustris $\mathrm{L}$. & Fowl bluegrass & FACW & PNG \\
\hline 80 & Poa pratensis $\mathrm{L}$. & Kentucky bluegrass & FACU & PNG \\
\hline 353 & Polygonum pensylvanicum $\mathrm{L}$. & Pennsyivania smartweed & FACW & ANEF \\
\hline 59 & Ranunculus acris $\mathrm{L}$. & Tall butter-cup & $\mathrm{FAC+}$ & PIF \\
\hline 354 & Ranunculus sceleratus $\mathrm{L}$. & Celery-leaf butter-cup & OBL & APNEF \\
\hline 32 & Rhamnus cathartica L. & Common buckthorn & UPL & IS \\
\hline 332 & Rumex sp. & & & \\
\hline 9 & Salix discolor Muhl. & Pussy willow & FACW & NS \\
\hline 2 & Salix petiolaris Pursh & Meadow willow & $O B L$ & NS \\
\hline 10 & Scirpus atrovirens Willd. & Green bulrush & OBL & PNEGL \\
\hline 96 & Scirpus validus Vahl & Soft-stem bulrush & OBL & PNEGL \\
\hline 51 & Solanum dulcamara $\mathrm{L}$. & Climbing nightshade & FAC- & PIF \\
\hline 86 & Solidago narrow-leaved & & & \\
\hline 87 & Solidago wide-leaved & & & \\
\hline 0 & Toxicodendron radicans (L.) Kuntze & Poison ivy & FAC & NWW \\
\hline 343 & Trifolium repens $\mathrm{L}$. & White clover & FACU- & PIF \\
\hline 112 & Typha $\times$ glauca Godr. & Blue cattail & $\mathrm{OBL}$ & PNEF \\
\hline 33 & Ulmus americana $L$. & American elm & FACW- & NT \\
\hline 81 & Viburnum lentago $\mathrm{L}$. & Nannyberry & FAC & NTS \\
\hline 55 & Vicia cracca L. & Cow-vetch & UPL & NIF \\
\hline
\end{tabular}


TABLE C.4 (Cont.)

a Wetland indicator categories are assigned to plants in the United States on a regional basis. New York is in Region 1. See Appendix B for more detailed information on wetland indicator categories. A " + " following an indicator reveals a frequency toward the high end of the category (more frequently found in wetlands), while a "-" indicates a frequency toward the low end (less frequently found in wetlands).

b Plant characteristics and life-forms assigned to each species, as indicated in this column, are explained in Reed (1988). (See Appendix B, Section B.2, for definitions of life-forms and origins.) 
TABLE C.5 Percent Areal Coverage Estimates by Stratum for Plant Species in the Emergent Marsh Community

\begin{tabular}{|c|c|c|c|c|c|c|c|c|c|c|c|c|c|c|c|c|c|c|c|c|c|}
\hline \multirow{2}{*}{$\begin{array}{l}\text { Field } \\
\text { Number }\end{array}$} & \multirow[b]{2}{*}{ Species Scientific Name } & \multicolumn{5}{|c|}{ ENA } & \multicolumn{5}{|c|}{ North ROW } & \multicolumn{5}{|c|}{ South ROW } & \multicolumn{5}{|c|}{ WNA } \\
\hline & & $\mathrm{T} 1$ & $\mathrm{~T} 2$ & T3 & T4 & T5 & $\mathrm{T} 1$ & $\mathrm{~T} 2$ & T3 & T4 & T5 & T1 & $\mathrm{T} 2$ & T3 & $\mathrm{T} 4$ & T5 & T1 & $\mathrm{T} 2$ & T3 & T4 & T5 \\
\hline \multirow{2}{*}{\multicolumn{2}{|c|}{$\begin{array}{l}\text { Exposed mineral soil } \\
\text { Standing water. }\end{array}$}} & - & - & - & - & - & 20 & 15 & 3 & 1 & - & 10 & 1 & 5 & 1 & - & - & - & - & - & - \\
\hline & & 5 & 15 & 5 & 35 & 55 & 10 & 15 & 50 & 50 & 50 & 30 & 40 & 20 & 50 & 80 & 2 & 15 & 5 & 1 & 2 \\
\hline \multicolumn{22}{|c|}{ Herb stratum } \\
\hline 42 & Acer saccharinum & 0.5 & - & - & - & - & - & - & - & - & - & - & - & - & - & - & - & 0.5 & - & - & - \\
\hline 351 & Acorus calamus & - & - & - & - & - & - & - & - & - & 0.5 & $\therefore$ & - & - & - & - & - & - & - & - & - \\
\hline 361 & Agrostis stolonifera & - & - & - & - & - & 1 & 1 & - & - & - & 2 & 1. & - & - & - & 1 & - & 0.5 & - & - \\
\hline 1 & Alisma plantago-aquatica & - & 0.5 & - & - & - & 1 & 1 & 5 & 12 & 2 & 10 & 5 & 5 & 5 & 1 & - & - & - & - & - \\
\hline 23 & Asclepias incarnata & 0.5 & 0.5 & - & 0.5 & 0.5 & 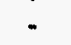 & - & - & - & - & - & - & - & - & - & - & 0.5 & 0.5 & 0.5 & 0.5 \\
\hline 76 & Bidens cernua & - & - & - & - & - & 0.5 & 0.5 & - & 1 & 0.5 & - & 0.5 & 0.5 & 0.5 & - & - & - & - & - & - \\
\hline 342 & Calamagrostis canadensis & - & - & 0.5 & - & - & 0.5 & - & - & - & - & - & - & - & - & - & - & - & - & 0.5 & - \\
\hline 355 & Calystegia sepium & - & - & 0.5 & - & - & - & - & - & - & - & - & - & - & - & - & - & - & - & - & 0.5 \\
\hline 17 & Carex bebbii & - & - & 1 & - & - & - & * & - & - & - & - & - & - & - & - & 0.5 & - & 1 & - & 1 \\
\hline 367 & Carex comosa & 0.5 & - & - & - & - & - & - & - & - & - & - & - & - & - & - & 1 & 1 & - & - & - \\
\hline 36 & Carex crinita & 0.5 & 1 & 0.5 & - & - & - & - & - & - & - & - & - & - & - & - & - & - & 1 & 2 & - \\
\hline 82 & Carex flava & 0.5 & - & - & - & - & - & - & - & - & - & - & - & - & -. & - & - & - & - & - & - \\
\hline 366 & Carex hystericina & 0.5 & - & - & - & - & - & - & - & - & - & - & - & - & - & - & - & - & - & - & - \\
\hline 350 & Carex lasiocarpa & - & - & 0.5 & - & - & - & - & - & - & - & - & - & - & - & - & - & $\cdot$ & - & - & - \\
\hline 12 & Carex lupulina & - & 3 & 0.5 & - & - & - & - & - & - & - & - & - & - & - & - & 1 & 0.5 & 2 & 1 & 0.5 \\
\hline 66 & Carex normalis & 0.5 & 1 & - & - & - & - & 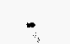 & - & - & - & - & - & - & - & - & - & 2 & 0.5 & - & - \\
\hline 91 & Carex pallescens & - & 0.5 & - & - & - & - & - & - & - & - & - & - & - & - & - & - & - & - & - & - \\
\hline 67 & Carex retrorsa & - & - & - & 0.5 & - & - & - & - & - & - & - & - & - & - & - & 0.5 & 0.5 & - & - & - \\
\hline 85 & Carex scoparia & - & - & 0.5 & - & - & - & - & - & - & - & - & - & - & $\cdot$ & - & - & 0.5 & 1 & 0.5 & - \\
\hline 331 & Carex spp. & - & - & - & - & - & 1 & 1 & 2 & 1 & 3 & 1 & 2 & - & 0.5 & 1 & - & - & - & - & - \\
\hline 75 & Carex suberecta & $\cdot$ & - & - & - & - & - & - & - & - & - & - & - & - & - & - & - & - & - & 0.5 & 0.5 \\
\hline 364 & Carex tenera & - & 0.5 & - & - & - & - & - & - & - & - & - & - & - & - & - & - & - & - & - & - \\
\hline 19 & Carex vulpinoidea & - & - & 1 & - & - & - & 0.5 & - & - & - & - & - & - & - & - & 0.5 & - & - & - & - \\
\hline 7 & Carex $\times$ stipata & - & 0.5 & 0.5 & - & - & - & - & - & - & - & - & - & - & - & - & - & - & 0.5 & 1 & 0.5 \\
\hline 218 & Cicuta bulbifera & - & - & - & - & 0.5 & - & 0.5 & - & 0.5 & - & - & - & - & - & - & $\cdot$ & 0.5 & - & 0.5 & - \\
\hline 53 & Cicuta maculata & 10 & 20 & 2 & 0.5 & 0.5 & 0.5 & 0.5 & - & 0.5 & - & 0.5 & - & - & 0.5 & - & 15 & 15 & 20 & 2 & 0.5 \\
\hline 6 & Cornus amomum & - & 2 & 0.5 & - & - & - & - & - & - & - & - & - & - & - & - & - & - & - & 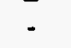 & - \\
\hline 5 & Cornus stolonifera & 0.5 & 0.5 & 0.5 & - & - & - & - & - & - & - & - & - & - & - & - & - & - & - & 0.5 & - \\
\hline 370 & Dryopteris spinulosa & - & - & $\therefore$ & - & - & - & - & - & - & - & - & - & - & - & - & - & - & 0.5 & - & - \\
\hline 333 & Eleocharis sp. & - & - & - & - & - & 2 & 1 & 0.5 & 0.5 & 5 & 1 & - & 0.5 & - & 0.5 & 0.5 & - & - & - & - \\
\hline 102 & Epilobium hirsutum & - & - & $\cdot$ & 0.5 & - & - & - & - & - & - & - & - & - & - & $\cdot$ & - & - & - & - & 0.5 \\
\hline 20 & Equisetum arvense & 15 & 10 & 20 & - & - & 1 & 0.5 & 4 & - & - & - & - & 5 & - & - & 3 & 10 & - & - & - \\
\hline 62 & Equisetum fluviatile & - & - & 0.5 & 85 & 60 & - & - & 1 & 15 & 4 & - & - & - & 15 & 5 & 0.5 & - & 10 & 60 & 75 \\
\hline 29 & $\begin{array}{l}\text { Eupatoriadelphus } \\
\text { maculatus }\end{array}$ & 10 & 5 & 10 & 15 & 5 & 1 & - & - & 0.5 & 1 & - & 0.5 & - & - & 0.5 & 25 & 10 & 20 & 15 & 25 \\
\hline
\end{tabular}




\begin{tabular}{|c|c|c|c|c|c|c|c|c|c|c|c|c|c|c|c|c|c|c|c|c|c|}
\hline \multirow[b]{2}{*}{$\begin{array}{l}\text { Field } \\
\text { Number }\end{array}$} & \multirow[b]{2}{*}{ Species Scientific Name } & \multicolumn{5}{|c|}{ ENA } & \multicolumn{5}{|c|}{ North ROW } & \multicolumn{5}{|c|}{ South ROW } & \multicolumn{5}{|c|}{ WNA } \\
\hline & & T1 & T2 & T3 & T4 & T5 & T1 & T2 & T3 & T4 & T5 & T1 & T2 & T3 & T4 & T5 & T1 & $\mathrm{T} 2$ & T3 & T4 & T5 \\
\hline 27 & Eupatorium perfoliatum & - & - & - & - & 0.5 & - & 1 & - & - & 0.5 & - & - & 0.5 & - & - & - & 0.5 & - & 0.5 & 0.5 \\
\hline 43 & Fraxinus pennsylvanica & - & - & - & - & - & - & - & - & - & - & - & - & - & - & - & - & - & 0.5 & - & \\
\hline 61 & Galium palustre & 10 & 5 & 5 & 10 & 3 & 1 & 0.5 & - & 0.5 & 0.5 & 0.5 & 0.5 & 1 & 0.5 & 0.5 & 5 & 20 & 5 & 2 & 20 \\
\hline 325 & Glyceria striata & & 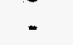 & - & $\cdot$ & - & - & - & - & - & 0.5 & - & - & - & 0.5 & - & - & - & 0.5 & - & - \\
\hline 111 & Impations capensis & 10 & 10 & 20 & 30 & 30 & 1 & - & 0.5 & 0.5 & - & - & - & 1 & 0.5 & 0.5 & 20 & 20 & 25 & 60 & 60 \\
\hline 57 & Iris versicolor & 1 & 5 & 0.5 & 0.5 & 1 & : & 0.5 & - & - & - & - & - & 0.5 & - & 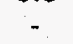 & 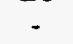 & 2 & 1 & 1 & 0.5 \\
\hline 84 & Juncus bufonius & : & - & - & - & : & 2 & 1 & 0.5 & 0.5 & 1 & 1 & 3 & 1 & 0.5 & 0.5 & - & . & - & - & - \\
\hline 371 & Juncus canadensis & - & - & - & - & - & - & 0.5 & 0.5 & 0.5 & 0.5 & 0.5 & 1 & - & - & 0.5 & - & - & - & - & - \\
\hline 365 & Juncus tenuis & - & - & - & - & - & - & - & - & - & - & - & - & 0.5 & 0.5 & - & - & - & - & - & - \\
\hline 380 & Leersia oryzoldes & - & - & 1 & - & 0.5 & - & - & - & - & - & - & - & - & - & - & - & - & 10 & 20 & - \\
\hline 46 & Lemna minor & - & - & - & 0.5 & & - & - & 0.5 & - & 0.5 & - & - & 0.5 & 0.5 & 0.5 & - & - & - & - & - \\
\hline 373 & Lemna trisulca & - & - & - & - & - & - & - & - & - & - & - & - & - & - & 0.5 & - & - & - & - & - \\
\hline 98 & Liparis loeselii & - & - & - & - & - & - & - & - & - & - & - & - & - & - & - & - & - & - & - & - \\
\hline 335 & Lolium perenne & - & - & - & - & - & - & - & - & - & 0.5 & - & - & - & - & - & - & - & - & - & - \\
\hline 72 & Ludwegia palustris & - & - & . & - & - & 1 & 0.5 & 0.5 & 0.5 & 1 & 1 & 0.5 & 0.5 & 0.5 & 2 & - & - & - & - & - \\
\hline 77 & Lycopus americanus & - & - & 0.5 & - & 0.5 & 0.5 & & - & - & - & 1 & - & - & - & - & 0.5 & 0.5 & - & 1 & 0.5 \\
\hline 93 & Lycopus uniflorus & - & - & - & - & - & - & - & - & - & - & - & - & - & - & - & - & - & - & - & - \\
\hline 26 & Lysimachia nummularia & - & - & 0.5 & - & - & - & - & - & - & - & - & - & - & - & - & - & - & 0.5 & - & - \\
\hline 74 & Lysimachia thyrsiflora & - & - & - & - & - & - & - & - & - & - & - & - & - & - & - & - & - & - & - & - \\
\hline 101 & Mentha spp. & - & - & - & - & - & - & - & - & - & - & - & - & - & - & - & - & - & - & - & - \\
\hline 97 & Nasturtium officinale & 10 & - & 10 & 0.5 & - & - & 0.5 & 0.5 & - & - & - & 0.5 & 0.5 & - & - & - & - & - & - & - \\
\hline 8 & Onoclea sensibilis & - & 15 & 50 & - & 2 & - & $\cdot$ & 2 & . & - & - & $\because$ & 1 & - & - & - & 0.5 & 15 & - & - \\
\hline 363 & Oxalis europaea & - & 0.5 & . & - & - & - & - & - & - & - & - & - & - & - & - & - & - & - & - & - \\
\hline 362 & Phleum pratensis & - & 0.5 & - & . & - & - & . & - & - & - & - & - & - & - & - & - & - & - & - & - \\
\hline 368 & Poa palustris & 0.5 & - & & - & - & - & - & - & - & - & - & - & - & - & - & - & - & 0.5 & - & 0.5 \\
\hline 80 & Poa pr & - & - & 0.5 & - & - & - & 0.5 & . & - & - & 0.5 & - & 0.5 & - & - & 10 & 0.5 & - & - & - \\
\hline 353 & Polygonum pensylvanicum & - & - & - & - & - & - & - & - & 0.5 & 0.5 & - & - & - & - & 0.5 & - & - & - & - & - \\
\hline 59 & Ranunculus acris & 0.5 & - & - & - & - & - & - & - & - & - & - & 0.5 & 0.5 & - & - & - & - & 0.5 & - & - \\
\hline 354 & Ranunculus sceleratus & - & - & - & - & - & - & - & - & - & - & - & 0.5 & & - & 0.5 & - & - & - & - & - \\
\hline 32 & Rhamnus cathartica & - & - & - & - & - & - & - & - & - & - & - & - & - & - & - & - & - & - & - & - \\
\hline 332 & Rumex sp. & - & - & - & - & 0.5 & - & - & - & - & - & - & - & - & - & - & - & 0.5 & - & - & 0.5 \\
\hline 2 & Salix petiolaris & - & - & - & - & - & 0.5 & - & - & - & - & 1 & - & 0.5 & - & - & - & & - & - & - \\
\hline 10 & Scirpus atrovirens & - & - & 0.5 & - & - & - & - & - & - & - & - & - & - & - & - & - & 0.5 & 0.5 & 5 & 1 \\
\hline 96 & Scirpus validus & . & - & . & . & 2 & - & - & - & - & - & - & - & - & - & - & - & - & 1 & - & - \\
\hline 51 & Solanum dulcamara & . & - & . & - & - & - & - & - & - & - & - & - & - & - & - & - & - & 0.5 & - & - \\
\hline 86 & Solidago (narrow leaves) & 0.5 & - & 0.5 & 0.5 & - & - & - & - & - & - & - & - & - & - & - & 0.5 & 1 & 0.5 & - & 0.5 \\
\hline 87 & Solidago (wide leaves) & 0.5 & 0.5 & 0.5 & - & - & - & - & & - & - & - & - & - & - & - & 0.5 & & 0.5 & - & 0.5 \\
\hline
\end{tabular}


TABLE C.5 (Cont.)

\begin{tabular}{|c|c|c|c|c|c|c|c|c|c|c|c|c|c|c|c|c|c|c|c|c|c|}
\hline \multirow{2}{*}{$\begin{array}{l}\text { Field } \\
\text { Number }\end{array}$} & \multirow[b]{2}{*}{ Species Scientific Name } & \multicolumn{5}{|c|}{ ENA } & \multicolumn{5}{|c|}{ North Row } & \multicolumn{5}{|c|}{ South ROW } & \multicolumn{5}{|c|}{ WNA } \\
\hline & & $\mathrm{T} 1$ & T2 & T3 & T4 & T5 & T1 & T2 & T3 & T4 & T5 & T1 & T2 & T3 & T4 & T5 & T1 & $\mathrm{T} 2$ & T3 & T4 & T5 \\
\hline 0 & Toxicodendron radicans & - & - & - & - & - & - & 0.5 & $\therefore$ & - & - & - & - & 0.5 & . & - & - & - & - & - & - \\
\hline 343 & Trifolium repens & - & - & - & - & - & 0.5 & 0.5 & - & - & 0.5 & - & 0.5 & 0.5 & 0.5 & - & - & - & - & - & - \\
\hline 112 & Typha $\times$ glauca & 35 & 40 & 80 & 95 & 95 & 5 & 1 & 3 & 10 & 10 & 1 & 1 & 2 & 10 & 5 & 95 & 75 & 50 & 75 & 90 \\
\hline 33 & Uimus americana & 0.5 & - & - & - & - & - & - & - & - & 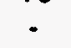 & - & - & - & - & - & - & - & - & - & - \\
\hline 55 & Vicia cracca & 10 & 1 & - & - & - & 0.5 & - & - & - & - & - & - & - & - & - & 10 & - & - & 0.5 & - \\
\hline \multicolumn{22}{|c|}{ Shrub stratum } \\
\hline 6 & Cornus amomum & 2 & 60 & 30 & - & 2 & - & - & - & - & - & - & - & - & - & - & - & 20 & 70 & 0.5 & - \\
\hline 90 & Cornus foemina & - & - & - & - & - & - & - & - & - & - & - & - & - & - & - & - & - & 0.5 & - & - \\
\hline 5 & Cornus stolonifera & 10 & 10 & 30 & - & 0.5 & - & - & - & - & - & - & - & - & - & - & - & - & 10 & 60 & 10 \\
\hline 38 & Fraxinus pennsylvanica & - & - & - & - & - & - & - & - & - & - & - & - & - & - & - & - & 1 & 0.5 & - & - \\
\hline 32 & Rhamnus cathartica & - & 60 & 0.5 & - & - & - & - & - & - & - & - & - & - & - & - & - & - & - & - & - \\
\hline 39 & Salix discolor & - & 30 & - & 1 & - & - & - & - & - & - & - & - & - & - & - & - & - & - & - & - \\
\hline 71 & Salix petiolaris & - & 20 & 5 & 4 & 2 & - & - & - & - & - & - & - & - & - & - & 5 & 50 & 5 & 1 & - \\
\hline 81 & Viburnum lentago & - & - & 0.5 & - & - & - & - & - & - & - & - & - & . & - & - & - & - & - & - & - \\
\hline
\end{tabular}


TABLE C.6 Average Percent Coverage, Absolute Frequencies, and Distribution by Stratum for Plant Species in the Emergent Marsh Community

\begin{tabular}{|c|c|c|c|c|c|}
\hline \multirow[b]{2}{*}{$\begin{array}{l}\text { Field } \\
\text { Number }\end{array}$} & \multirow[b]{2}{*}{ Species Scientific Name } & \multicolumn{4}{|c|}{$\begin{array}{c}\text { Average Percent Coverage/ } \\
\text { Absolute Frequency }\end{array}$} \\
\hline & & ENA & $\begin{array}{l}\text { East } \\
\text { ROW }\end{array}$ & $\begin{array}{l}\text { West } \\
\text { ROW }\end{array}$ & WNA \\
\hline \multicolumn{2}{|l|}{ Standing Water } & $23 / 5$ & $35 / 5$ & $44 / 5$ & $5 / 5$ \\
\hline \multicolumn{2}{|l|}{ Soil } & 0.010 & $7.8 / 4$ & $4.25 / 5$ & $0.0 / 0$ \\
\hline \multicolumn{6}{|c|}{ HERB STRATUM } \\
\hline & \multicolumn{5}{|l|}{ Plants found in both NAs and both sides of } \\
\hline & ROW & & & & \\
\hline 53 & Cicuta maculata & $6.6 / 5$ & $0.3 / 3$ & $0.2 / 2$ & $10.5 / 5$ \\
\hline 20 & Equisetum arvense & $9.0 / 3$ & $1.1 / 3$ & $1.0 / 1$ & $2.6 / 2$ \\
\hline 62 & Equisetum fluviatile & $29.1 / 3$ & $4.0 / 3$ & $4.0 / 2$ & $29.1 / 4$ \\
\hline 29 & Eupatoriadelphus maculatus & $9.0 / 5$ & $0.5 / 3$ & $0.2 / 2$ & $19.0 / 5$ \\
\hline 27 & Eupatorium perfoliatum & $0.1 / 1$ & $0.3 / 2$ & $0.1 / 1$ & $0.3 / 3$ \\
\hline 61 & Galium palustre & $6.6 / 5$ & $0.5 / 4$ & $0.6 / 5$ & $10.4 / 5$ \\
\hline 111 & Impatiens capensis & $20.0 / 5$ & $0.4 / 3$ & $0.4 / 3$ & $37.0 / 5$ \\
\hline 57 & Iris versicolor & $1.6 / 5$ & $0.1 / 1$ & $0.1 / 1$ & $0.9 / 4$ \\
\hline 77 & Lycopus americanus & $0.2 / 2$ & $0.1 / 1$ & $0.2 / 1$ & $0.5 / 4$ \\
\hline 8 & Onoclea sensibilis & $13.4 / 3$ & $0.4 / 1$ & $0.2 / 1$ & $3.1 / 2$ \\
\hline 80 & Poa pratensis & $0.1 / 1$ & $0.1 / 1$ & $0.2 / 2$ & $2.1 / 2$ \\
\hline \multirow[t]{2}{*}{112} & Typha $\times$ glauca & $69.0 / 5$ & $5.8 / 5$ & $3.8 / 5$ & $77.0 / 5$ \\
\hline & $\begin{array}{l}\text { Plants found in both NAs and east side of } \\
\text { ROW }\end{array}$ & & & & \\
\hline 342 & Calamagrostis canadensis & $0.1 / 1$ & $0.1 / 1$ & $0.0 / 0$ & $0.1 / 1$ \\
\hline 19 & Carex vulpinoidea & $0.2 / 1$ & $0.1 / 1$ & $0.0 / 0$ & $0.1 / 1$ \\
\hline 218 & Cicuta bulbifera & $0.1 / 1$ & $0.2 / 2$ & $0.0 / 0$ & $0.2 / 2$ \\
\hline \multirow[t]{3}{*}{55} & Vicia cracca & $2.2 / 2$ & $0.1 / 1$ & $0.0 / 0$ & $2.1 / 2$ \\
\hline & Plant found in both NAs and west side of & & & & \\
\hline & ROW & & & & \\
\hline \multirow[t]{2}{*}{59} & $\overline{R a n u n c u l u s ~ a c r i s}$ & $0.1 / 1$ & $0.0 / 0$ & $0.2 / 2$ & $0.1 / 1$ \\
\hline & Plants found in both NAs only & & & & \\
\hline 42 & Acer saccharinum & $0.1 / 1$ & $0.0 / 0$ & $0.0 / 0$ & $0.1 / 1$ \\
\hline 23 & Asclepias incarnata & $0.4 / 4$ & $0.0 / 0$ & $0.0 / 0$ & $0.4 / 4$ \\
\hline 355 & Calystegia sepium & $0.1 / 1$ & $0.0 / 0$ & $0.0 / 0$ & $0.1 / 1$ \\
\hline 17 & Carex bebbii & $0.2 / 1$ & $0.0 / 0$ & $0.0 / 0$ & $0.5 / 3$ \\
\hline 367 & Carex comosa & $0.1 / 1$ & 0.010 & $0.0 / 0$ & $0.4 / 2$ \\
\hline 36 & Carex crinita & $0.4 / 3$ & $0.0 / 0$ & $0.0 / 0$ & $0.6 / 2$ \\
\hline 12 & Carex lupulina & $0.7 / 2$ & 0.010 & $0.0 / 0$ & $0.8 / 4$ \\
\hline 66 & Carex normalis & $0.3 / 2$ & $0.0 / 0$ & $0.0 / 0$ & $0.5 / 2$ \\
\hline 67 & Carex retrorsa & $0.1 / 1$ & $0.0 / 0$ & $0.0 / 0$ & $0.2 / 2$ \\
\hline 85 & Carex scoparia & $0.1 / 1$ & $0.0 / 0$ & $0.0 / 0$ & $0.4 / 3$ \\
\hline 7 & Carex $\times$ stipata & $0.2 / 2$ & $0.0 / 0$ & $0.0 / 0$ & $0.4 / 3$ \\
\hline
\end{tabular}




\begin{tabular}{|c|c|c|c|c|c|}
\hline \multirow[b]{2}{*}{$\begin{array}{l}\text { Field } \\
\text { Number }\end{array}$} & \multirow[b]{2}{*}{ Species Scientific Name } & \multicolumn{4}{|c|}{$\begin{array}{c}\text { Average Percent Coverage/ } \\
\text { Absolute Frequency }\end{array}$} \\
\hline & & ENA & $\begin{array}{l}\text { East } \\
\text { ROW }\end{array}$ & $\begin{array}{l}\text { West } \\
\text { ROW }\end{array}$ & WNA \\
\hline 5 & Cornus stolonifera & $0.3 / 3$ & $0.0 / 0$ & $0.0 / 0$ & $0.1 / 1$ \\
\hline 102 & Epilobium hirsutum & $0.1 / 1$ & $0.0 / 0$ & $0.0 / 0$ & $0.1 / 1$ \\
\hline 380 & Leersia oryzoides & $0.3 / 2$ & $0.0 / 0$ & $0.0 / 0$ & $6.0 / 2$ \\
\hline 26 & Lysimachia nummularia & $0.1 / 1$ & $0.0 / 0$ & 0.010 & $0.1 / 1$ \\
\hline 368 & Poa palustris & $0.1 / 1$ & $0.0 / 0$ & $0.0 / 0$ & $0.2 / 2$ \\
\hline 332 & Rumex sp. & $0.1 / 1$ & 0.010 & $0.0 / 0$ & $0.2 / 2$ \\
\hline 10 & Scirpus atrovirens & $0.1 / 1$ & $0.0 / 0$ & 0.010 & $1.4 / 4$ \\
\hline 96 & Scirpus validus & $0.4 / 1$ & $0.0 / 0$ & 0.010 & $0.2 / 1$ \\
\hline 86 & Solidago narrow leaved & $0.3 / 3$ & $0.0 / 0$ & $0.0 / 0$ & $0.5 / 4$ \\
\hline \multirow[t]{2}{*}{87} & Solidago wide leaved & $0.3 / 3$ & $0.0 / 0$ & $0.0 / 0$ & $0.3 / 3$ \\
\hline & Plants found in ENA and both sides of ROW & & & & \\
\hline 1 & Alisma plantago-aquatica & $0.1 / 1$ & $4.2 / 5$ & $5.2 / 5$ & $0.0 / 0$ \\
\hline 46 & Lemna minor & $0.1 / 1$ & $0.2 / 2$ & $0.3 / 3$ & $0.0 / 0$ \\
\hline \multirow[t]{2}{*}{97} & Nasturtium officinale & $4.1 / 3$ & $0.2 / 2$ & $0.2 / 2$ & $0.0 / 0$ \\
\hline & Plants found in ENA only & & & & \\
\hline 82 & Carex flava & $0.1 / 1$ & $0.0 / 0$ & $0.0 / 0$ & $0.0 / 0$ \\
\hline 366 & Carex hystericina & $0.1 / 1$ & $0.0 / 0$ & $0.0 / 0$ & $0.0 / 0$ \\
\hline 350 & Carex lasiocarpa & $0.1 / 1$ & $0.0 / 0$ & $0.0 / 0$ & $0.0 / 0$ \\
\hline 91 & Carex pallescens & $0.1 / 1$ & $0.0 / 0$ & $0.0 / 0$ & $0.0 / 0$ \\
\hline 364 & Carex tenera & $0.1 / 1$ & $0.0 / 0$ & $0.0 / 0$ & $0.0 / 0$ \\
\hline 6 & Cornus amomum & $0.5 / 2$ & $0.0 / 0$ & $0.0 / 0$ & $0.0 / 0$ \\
\hline 363 & Oxalis europaea & $0.1 / 1$ & $0.0 / 0$ & $0.0 / 0$ & $0.0 / 0$ \\
\hline 362 & Phleum pratensis & $0.1 / 1$ & $0.0 / 0$ & $0.0 / 0$ & $0.0 / 0$ \\
\hline \multirow[t]{2}{*}{33} & Ulmus americana & $0.1 / 1$ & $0.0 / 0$ & $0.0 / 0$ & $0.0 / 0$ \\
\hline & $\begin{array}{l}\text { Plants found in WNA and both sides of } \\
\text { ROW }\end{array}$ & & & & \\
\hline 361 & Agrostis stolonifera & $0.0 / 0$ & $0.4 / 2$ & $0.6 / 2$ & $0.3 / 2$ \\
\hline 333 & Eleocharis spp. & $0.0 / 0$ & $1.8 / 5$ & $0.4 / 3$ & $0.1 / 1$ \\
\hline \multirow[t]{2}{*}{325} & Glyceria striata & $0.0 / 0$ & $0.1 / 1$ & $0.1 / 1$ & $0.1 / 1$ \\
\hline & Plants found in WNA only & & & & \\
\hline 75 & Carex suberecta & $0.0 / 0$ & $0.0 / 0$ & $0.0 / 0$ & $0.2 / 2$ \\
\hline 370 & Dryopteris spinulosa & $0.0 / 0$ & $0.0 / 0$ & $0.0 / 0$ & $0.1 / 1$ \\
\hline 43 & Fraxinus pennsylvanica & $0.0 / 0$ & $0.0 / 0$ & $0.0 / 0$ & $0.1 / 1$ \\
\hline 51 & Solanum dulcamara & $0.0 / 0$ & $0.0 / 0$ & $0.0 / 0$ & $0.1 / 1$ \\
\hline
\end{tabular}


TABLE C.6 (Cont.)

\begin{tabular}{|c|c|c|c|c|c|}
\hline \multirow[b]{2}{*}{$\begin{array}{l}\text { Field } \\
\text { Number }\end{array}$} & \multirow[b]{2}{*}{ Species Scientific Name } & \multicolumn{4}{|c|}{$\begin{array}{c}\text { Average Percent Coverage/ } \\
\text { Absolute Frequency }\end{array}$} \\
\hline & & ENA & $\begin{array}{l}\text { East } \\
\text { ROW }\end{array}$ & $\begin{array}{l}\text { West } \\
\text { ROW }\end{array}$ & WNA \\
\hline & Plants found in both sides of ROW & & & & \\
\hline 76 & Bidens cernua & $0.0 / 0$ & $0.5 / 4$ & $0.3 / 3$ & $0.0 / 0$ \\
\hline 331 & Carex spp. & $0.0 / 0$ & $1.6 / 5$ & $0.9 / 4$ & 0.010 \\
\hline 84 & Juncus bufonius & $0.0 / 0$ & $1.0 / 5$ & $1.2 / 5$ & $0.0 / 0$ \\
\hline 371 & Juncus canadensis & $0.0 / 0$ & $0.4 / 4$ & $0.4 / 3$ & $0.0 / 0$ \\
\hline 72 & Ludwegia palustris & $0.0 / 0$ & $0.7 / 5$ & $0.9 / 5$ & $0.0 / 0$ \\
\hline 353 & Polygonum pensylvanicum & $0.0 / 0$ & $0.2 / 2$ & $0.1 / 1$ & $0.0 / 0$ \\
\hline 2 & Salix petiolaris & $0.0 / 0$ & $0.1 / 1$ & $0.3 / 2$ & $0.0 / 0$ \\
\hline 0 & Toxicodendron radicans & $0.0 / 0$ & $0.1 / 1$ & $0.1 / 1$ & $0.0 / 0$ \\
\hline \multirow[t]{2}{*}{343} & Trifolium repens & $0.0 / 0$ & $0.3 / 3$ & $0.3 / 3$ & $0.0 / 0$ \\
\hline & Plants found in east side of ROW only & & & & \\
\hline 351 & Acorus calamus & $0.0 / 0$ & $0.1 / 1$ & $0.0 / 0$ & $0.0 / 0$ \\
\hline \multirow[t]{2}{*}{335} & Lolium perenne & $0.0 / 0$ & $0.1 / 1$ & $0.0 / 0$ & $0.0 / 0$ \\
\hline & Plants found in west side of ROW only & & & & \\
\hline 365 & Juncus tenuis & $0.0 / 0$ & $0.0 / 0$ & $0.2 / 2$ & $0.0 / 0$ \\
\hline 373 & Lemna trisulca & $0.0 / 0$ & $0.0 / 0$ & $0.1 / 1$ & $0.0 / 0$ \\
\hline \multirow[t]{2}{*}{354} & Ranunculus sceleratus & $0.0 / 0$ & $0.0 / 0$ & $0.2 / 2$ & $0.0 / 0$ \\
\hline & $\begin{array}{l}\text { Plants found within site but not within } \\
\text { plots }\end{array}$ & & & & \\
\hline 98 & Liparis loeselii & $0.0 / 0$ & $0.0 / 0$ & 0.010 & 0.010 \\
\hline 93 & Lycopus uniflorus & $0.0 / 0$ & $0.0 / 0$ & $0.0 / 0$ & $0.0 / 0$ \\
\hline 74 & Lysimachia thyrsiflora & $0.0 / 0$ & $0.0 / 0$ & $0.0 / 0$ & $0.0 / 0$ \\
\hline 101 & Mentha sp. & $0.0 / 0$ & $0.0 / 0$ & $0.0 / 0$ & $0.0 / 0$ \\
\hline \multicolumn{6}{|c|}{ SHRUB STRATUM } \\
\hline & Plants found in both NAs & & & & \\
\hline 6 & Cornus amomum & $18.8 / 4$ & $0.0 / 0$ & $0.0 / 0$ & $18.1 / 3$ \\
\hline 5 & Cornus stolonifera & $10.1 / 4$ & $0.0 / 0$ & $0.0 / 0$ & $16.0 / 3$ \\
\hline \multirow[t]{2}{*}{71} & Salix petiolaris & $6.2 / 4$ & $0.0 / 0$ & $0.0 / 0$ & $12.2 / 4$ \\
\hline & Plants found in ENA only & & & & \\
\hline 32 & Rhamnus cathartica & $12.1 / 2$ & $0.0 / 0$ & $0.0 / 0$ & $0.0 / 0$ \\
\hline 39 & Salix discolor & $6.2 / 2$ & $0.0 / 0$ & $0.0 / 0$ & $0.0 / 0$ \\
\hline \multirow[t]{2}{*}{81} & Viburnum lentago & $0.1 / 1$ & $0.0 / 0$ & $0.0 / 0$ & $0.0 / 0$ \\
\hline & Plants found in WNA only & & & & \\
\hline 90 & Cornus foemina & $0.0 / 0$ & $0.0 / 0$ & $0.0 / 0$ & $0.1 / 1$ \\
\hline 38 & Fraxinus pennsylvanica & $0.0 / 0$ & $0.0 / 0$ & $0.0 / 0$ & $0.3 / 2$ \\
\hline
\end{tabular}


TABLE C.7 Plant Species List - Forested Wetland Community

\begin{tabular}{|c|c|c|c|c|}
\hline $\begin{array}{l}\text { Field } \\
\text { Number }\end{array}$ & $\begin{array}{c}\text { Species Scientific Name and } \\
\text { Authority }\end{array}$ & Common Name & $\begin{array}{l}\text { Region } 1 \\
\text { Wetland } \\
\text { Indicator } \\
\text { Category }\end{array}$ & $\begin{array}{l}\text { Life } \\
\text { Form } \\
\text { and } \\
\text { Origin }^{\mathrm{b}}\end{array}$ \\
\hline 42 & Acer saccharinum $\mathrm{L}$. & Silver maple & FACW & NT \\
\hline 351 & Acorus calamus $\mathrm{L}$. & Sweetflag & OBL & PIEF \\
\hline 1 & Alisma plantago-aquatica $\mathrm{L}$. & Broad-leaf water plantain & $\mathrm{OBL}$ & PNEF \\
\hline 334 & Ambrosia artemisiifolia L. & Annual ragweed & FACU & ANF \\
\hline 374 & Arisaema triphyllum (L.) Schott & Swamp jack-in-the-pulpit & FACW- & PNF \\
\hline 392 & Aster spp. & & & \\
\hline 113 & Athyrium filix-femina (L.) Roth & Subarctic lady fern & FAC & PNF3 \\
\hline 76 & Bidens cernua L. & Nodding beggar-ticks & OBL & AlF \\
\hline 370 & Bidens frondosa $L$. & Devil's beggar-ticks & FACW & ANF \\
\hline 377 & Caltha palustris L. & Common marsh-marigold & OBL & PNF \\
\hline 315 & $\begin{array}{l}\text { Carex bebbii (L.H. Bailey) Olney ex } \\
\text { Fernald }\end{array}$ & Bebb's sedge & OBL & PNGL \\
\hline 314 & Carex bromoides Schkuhr & Broom-like sedge & FACW & PNGL \\
\hline 323 & Carex crinita Lam. & Fringed sedge & OBL & PNEGL \\
\hline 321 & Carex flava $\mathrm{L}$. & Yellow sedge & $\mathrm{OBL}$ & PNGL \\
\hline 318 & Carex lupulina Muhl. ex Willd. & Hop sedge & OBL & PNEGL \\
\hline 316 & Carex normalis Mackenz. & Larger straw sedge & FACU & PNGL \\
\hline 320 & Carex sp. & & & \\
\hline 352 & Cicuta bulbifera $\mathrm{L}$. & $\begin{array}{l}\text { Bublet-bearing } \\
\text { water-hemlock }\end{array}$ & OBL & PNF \\
\hline 53 & Cicuta maculata L. & Spotted water-hemlock & OBL & PNF \\
\hline 313 & Cinna arundinacea $\mathrm{L}$. & Stout wood-reedgrass & FACW+ & PNG \\
\hline 224 & Circaea lutetiana L. & $\begin{array}{l}\text { Southern broad-leaf } \\
\text { enchanter's nightshade }\end{array}$ & FACU & PNF \\
\hline 6 & Cornus amomum Mill & Silky dogwood & FACW & NS \\
\hline 370 & $\begin{array}{l}\text { Dryopteris spinulosa } \\
\text { (O.F. Muell.) Watt }\end{array}$ & Spinulose woodfern & $\mathrm{FAC}+$ & F3 \\
\hline 300 & $\begin{array}{l}\text { Eleocharis obtusa (Willd.) } \\
\text { J.A. Schultes }\end{array}$ & Blunt spikerush & OBL & APNEGL \\
\hline 20 & Equisetum arvense $\mathrm{L}$. & Field horsetail & FAC & $\mathrm{PNH} 2$ \\
\hline 38 & Fraxinus pennys/vanica Marshall & Green ash & FACW & NT \\
\hline 319 & Galium plaustre $\mathrm{L}$. & Marsh bedstraw & OBL & PNF \\
\hline 216 & Geum canadense Jacq. & White avens & FACU & PNF \\
\hline 312 & Glyceria striata (Lam.) A. Hitchc. & Fowl manna grass & OBL & PNEG \\
\hline 111 & Impatiens capensis Meerb. & Spotted touch-me-not & FACW & ANF \\
\hline 365 & Juncus tenuis Willd. & Slender rush & FAC- & PNGL \\
\hline 374 & Lemna minor L. & Lesser duckweed & OBL & PN/F \\
\hline 373 & Lemna trisulca $\mathrm{L}$. & Star duckweed & OBL & PN/F \\
\hline 393 & Lilium philadelphicum L. & Wood lily & FACU+ & PNF \\
\hline 376 & Lolium perenne $\mathrm{L}$. & Perennial ryegrass & FACU- & $\mathrm{PIG}$ \\
\hline 44 & Lonicera tatarica $\mathrm{L}$. & Tartarian honeysuckle & FACU & IS \\
\hline 72 & Ludwegia palustris (L.) Elliot & Marsh seedbox & $\mathrm{OBL}$ & PNEF \\
\hline
\end{tabular}


TABLE C.7 (Cont.)

\begin{tabular}{|c|c|c|c|c|}
\hline $\begin{array}{l}\text { Field } \\
\text { Number }\end{array}$ & $\begin{array}{c}\text { Species Scientific Name and } \\
\text { Authority }\end{array}$ & Common Name & $\begin{array}{l}\text { Region } 1 \\
\text { Wetland } \\
\text { Indicator } \\
\text { Category }\end{array}$ & $\begin{array}{l}\text { Life } \\
\text { Form } \\
\text { and } \\
\text { Origin }^{b}\end{array}$ \\
\hline 72 & $\begin{array}{l}\text { Lycopus americanus Muhl. ex } \\
\text { W. Barton }\end{array}$ & American bugleweed & OBL & PNF \\
\hline 383 & Medicago lupulina $\mathrm{L}$. & Black medic & UPL & AIF \\
\hline 8 & Onoclea sensibilis $\mathrm{L}$. & Sensitive fern & FACW & PNEF3 \\
\hline 237 & $\begin{array}{l}\text { Parthenocisscus quinquefolia } \\
\text { (L.) Planch. }\end{array}$ & Virginia creeper & FACU & NWW \\
\hline 374 & Pilea pumila (L.) Gray & Canada clearweed & FACW & ANF \\
\hline 322 & Poa palustris $\mathrm{L}$. & Fowl bluegrass & FACW & PNG \\
\hline 389 & Quercus bicolor Willd. & Swamp white oak & $\mathrm{FACW}_{+}$ & NT \\
\hline 32 & Rhamnus cathartica L. & Common buckthorn & UPL & IS \\
\hline 110 & Rhamnus frangula $\mathrm{L}$. & Glossy buckthorn & FAC & is \\
\hline 34 & Ribes americanum Mill. & Wild black currant & FACW & NS \\
\hline 310 & Ribes cyanosbata $\mathrm{L}$. & Prickly gooseberry & UPL & NS \\
\hline 387 & Rosa palustris Marshall & Swamp rose & $\mathrm{OBL}$ & NS \\
\hline 117 & Rubus pubescens Raf. & Dwarf blackberry & FACW & PNF \\
\hline 388 & Rubus strigosus Michx. & Red raspberry & $\mathrm{NI}$ & PNS \\
\hline 330 & Salix fragilis $\mathrm{L}$. & Crack willow & $\mathrm{FAC}+$ & IT \\
\hline 391 & Sambucus canadensis $\mathrm{L}$. & American elder & FACW- & NS \\
\hline 385 & Solanum dulcamara $\mathrm{L}$. & Climbing nightshade & FAC- & PIF \\
\hline 390 & Sorbus americana Marshall & American mountain-ash & FACU & NT \\
\hline 369 & Sparganium spp. & & & \\
\hline 386 & Thalictrum pubescens Pursh. & Tall meadow-rue & $\mathrm{FACW}_{+}$ & PNF \\
\hline 0 & Toxicodendron radicans (L.) Knutze & Poison ivy & FAC & NWVS \\
\hline 343 & Trifolium repens $\mathrm{L}$. & White clover & FACU- & PIF \\
\hline 84 & Typha latifolia L. & Broad-leaf cattail & OBL & PNEF \\
\hline 12 & Typha $\times$ glauca Godr. & Blue cattail & $\mathrm{OBL}$ & PNEF \\
\hline 33 & Ulmus americana $\mathrm{L}$. & American elm & FACW- & NT \\
\hline 99 & Viburnum dentatum $\mathrm{L}$. & Arrow-wood & FAC & NTS \\
\hline 91 & Viburnum recognitum Fernald. & Northern arrow-wood & FACW- & NS \\
\hline 311 & Vitis riparia Michx. & River-bank grape & FACW & NUN \\
\hline
\end{tabular}

a Wetland indicator categories are assigned to plants in the United States on a regional basis. New York is in Region 1. See Appendix B for more detailed information on wetland indicator categories. A " + " following an indicator reveals a frequency toward the high end of the category (more frequently found in wetlands), while a "-" indicates a frequency toward the low end (less frequently found in wetlands).

b Plant characteristics and life-forms assigned to each species, as indicated in this column, are explained in Reed (1988). (See Appendix B, Section B.2 for definitions of life-forms and origins.) 
TABLE C.8 Percent Areal Coverage Estimates by Stratum for Plant Species in the Forested Wetland Community

\begin{tabular}{|c|c|c|c|c|c|}
\hline \multirow[b]{2}{*}{$\begin{array}{c}\text { Field } \\
\text { Number }\end{array}$} & \multirow[b]{2}{*}{ Species Scientific Name } & \multicolumn{4}{|c|}{ Average Percent Coverage } \\
\hline & & NNA & $\begin{array}{l}\text { North } \\
\text { ROW }\end{array}$ & $\begin{array}{l}\text { South } \\
\text { ROW }\end{array}$ & SNA \\
\hline \multicolumn{2}{|c|}{ Standing water } & - & 75 & 2 & - \\
\hline \multicolumn{2}{|c|}{ Exposed mineral soil } & - & 10 & 25 & - \\
\hline \multicolumn{2}{|c|}{ Exposed embedded logs } & - & - & 15 & - \\
\hline \multicolumn{6}{|c|}{ HERB STRATUM } \\
\hline & \multicolumn{5}{|c|}{ Plants found in both NAs and south side of } \\
\hline 42 & $\overline{\text { Acer saccharinum }}$ & 0.5 & - & 0.5 & 0.5 \\
\hline 76 & Bidens cemua & 0.5 & - & 2 & 1 \\
\hline 370 & Bidens frondosa & 0.5 & - & 0.5 & 0.5 \\
\hline 312 & Glyceria striata & 1 & - & 0.5 & 10 \\
\hline 111 & Impatiens capensis & 2 & - & 3 & 5 \\
\hline \multirow[t]{2}{*}{33} & Ulmus americana & 1 & - & 0.5 & 0.5 \\
\hline & \multicolumn{5}{|l|}{ Plants found in both NAs } \\
\hline 318 & Carex lupulina & 0.5 & - & - & 0.5 \\
\hline 320 & Carex spp. & 0.5 & - & - & 0.5 \\
\hline 370 & Dryopteris spinulosa & 0.5 & - & - & 0.5 \\
\hline 38 & Fraxinus pennys/vanica & 0.5 & - & - & 3 \\
\hline 44 & Lonicera tatarica & 0.5 & - & - & 0.5 \\
\hline 8 & Onoclea sensibilis & 25 & - & - & 0.5 \\
\hline 237 & Parthenocisscus quinquefolia & 3 & - & - & 0.5 \\
\hline 32 & Rhamnus cathartica & 10 & - & - & 3 \\
\hline 110 & Rhamnus frangula & 0.5 & - & - & 0.5 \\
\hline 34 & Ribes americanum & 1 & - & - & 0.5 \\
\hline 117 & Rubus pubescens & 1 & - & - & 3 \\
\hline 390 & Sorbus americana & 0.5 & - & - & 0.5 \\
\hline 0 & Toxicodendron radicans & 0.5 & - & - & 4 \\
\hline 384 & Typha latifolia & 1 & - & - & 1 \\
\hline \multirow[t]{2}{*}{91} & Viburnum recognitum & 1 & - & - & 0.5 \\
\hline & \multicolumn{3}{|l|}{ Plants found in NNA and south side of } & ROW & \\
\hline 1 & Alisma plantago-aquatica & 0.5 & - & 0.5 & - \\
\hline \multirow[t]{2}{*}{72} & Ludwegia palustris & 0.5 & - & 0.5 & - \\
\hline & \multicolumn{5}{|l|}{ Plants found in NNA only } \\
\hline 113 & $\overline{\text { Athyrium filix-femina }}$ & 0.5 & - & - & - \\
\hline 365 & Jungus tenuis & 0.5 & - & - & - \\
\hline 393 & Lilium philadelphicum & 0.5 & - & - & - \\
\hline 72 & Lycopus americanus & 0.5 & - & - & - \\
\hline 310 & Ribes cyanosbata & 0.5 & - & - & - \\
\hline
\end{tabular}


TABLE C.8 (Cont.)

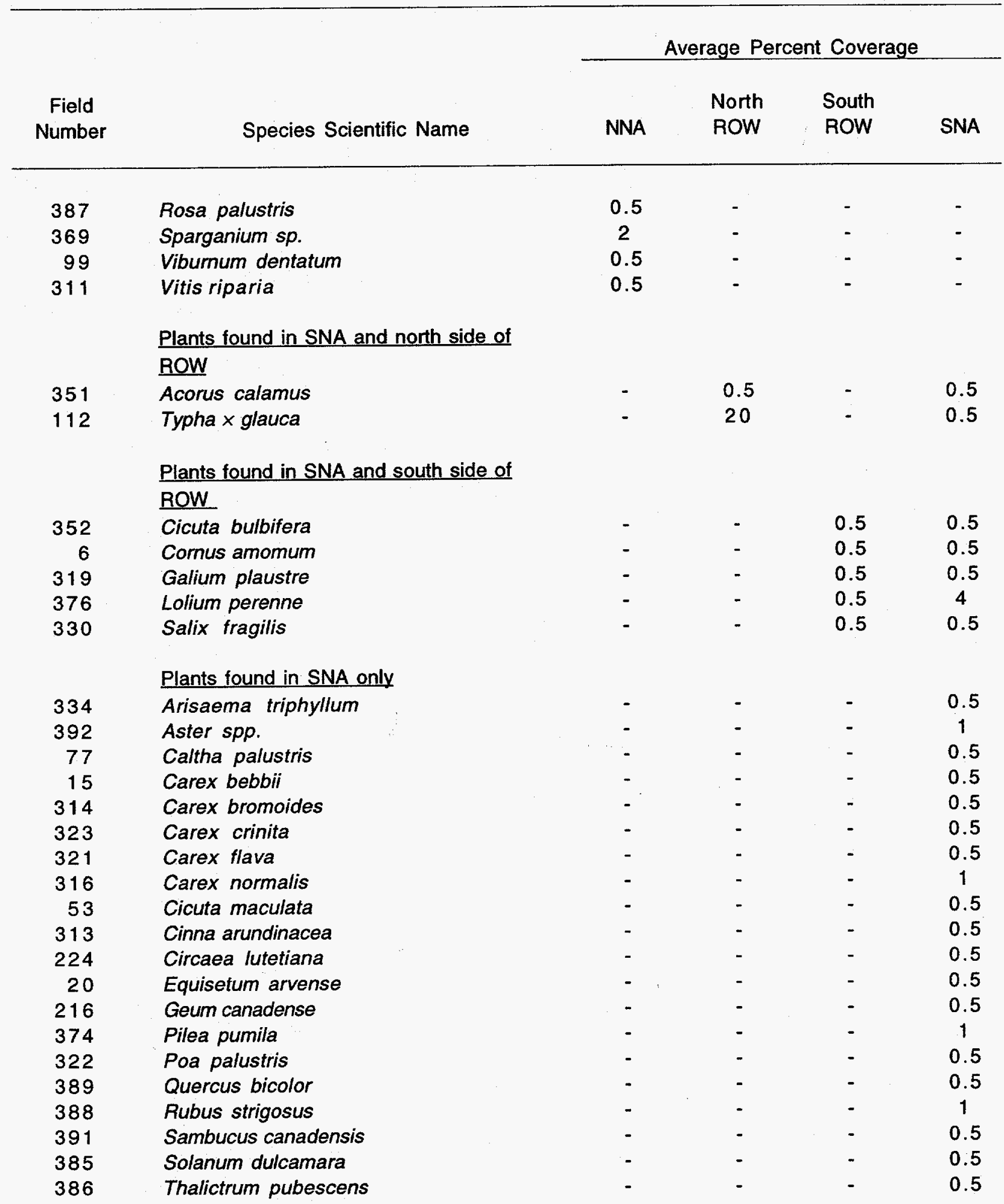


Average Percent Coverage

Field Number

Species Scientific Name

North

South

NNA ROW ROW

SNA

Plants found on north side of ROW only

374

373

\section{Lemna minor}

Lemna trisulca

Plants found on south side of ROW only

375

300

Ambrosia artemisiifolia

383

Eleocharis obtusa

Medicago Jupulina

343

\section{SHRUB STRATUM}

Plants found in both NAs

38 Fraxinus pennys/vanica

32 Rhamnus cathartica

0.5

20

Plants found in SNA only

42 Acer saccharinum

33 Ulmus americana

SAPLING STRATUM

Plant found in both NAs

42

Acer saccharinum

5

0.5

0.5

Plant found only in NNA

32 Rhamnus cathartica

2

TREE STRATUM

Plants found in both NAs

42 Acer saccharinum

38 Fraxinus pennys/vanica

50

1

Plants found in SNA only

Quercus bicolor

330

Salix fragilis

0.5

0.5

0.5

0.5 


\section{4}


Appendix D:

Comparisons of Plant Species Found on Each Site: 1991 and 1992 


\section{Appendix D: Comparisons of Plant Species Found on Each Site: 1991 and 1992}

TABLE D.1 Plant Species Present in Study Plots in 1991 Only Scrub-Shrub Community

\begin{tabular}{lllll}
\hline \multicolumn{1}{|c}{ Species Scientific Name } & $\begin{array}{l}\text { Wetland } \\
\text { Indicator } \\
\text { Category }\end{array}$ & $\begin{array}{c}\text { Life- } \\
\text { Form/ } \\
\text { Origin }\end{array}$ & Occurrence & $\begin{array}{c}\text { Percent } \\
\text { Coverage }\end{array}$ \\
\hline Carex $\times$ stipata & OBL & PNGL & NAs & 0.10 \\
Onoclea sensibilis & FACW & PNEF3 & NAs & 0.05 \\
$\begin{array}{l}\text { Populus deltoides } \\
\text { Rhamnus cathartica }\end{array}$ & FAC & NT & Both & $2.25(t)$ \\
Rhamnus frangula & UPL & IS & Both & 0.40 \\
Ribes americana & FAC & IS & Both & 0.10 \\
Solidago sp. & FACW & NS & NAs & 0.05 \\
\hline
\end{tabular}

a Plant characteristics and life-forms assigned to each species, as indicated in this column, are explained in Reed (1988). (See Appendix B, Section B.2, for definitions of life-forms and origins.)

b The species' greatest percent coverage is in the herb stratum unless otherwise noted: $(t)=$ tree.

c Plant species occurred in both the NAs and the ROW. 
TABLE D.2 Plant Species Present in Study Plots in 1992 Only Scrub-Shrub Community

\begin{tabular}{|c|c|c|c|c|}
\hline Species Scientific Name & $\begin{array}{l}\text { Wetland } \\
\text { Indicator } \\
\text { Category }\end{array}$ & $\begin{array}{l}\text { Life- } \\
\text { Form/ } \\
\text { Origin }\end{array}$ & Occurrence & $\begin{array}{l}\text { Percent } \\
\text { Coverage }\end{array}$ \\
\hline Alisma plantago-aquatica & OBL & PNEF & Both $\mathrm{c}$ & 4.50 \\
\hline Ambrosia artemisiifolia & FACU & ANF & NAs & 0.05 \\
\hline Bidens cemua & OBL & AIF & ROW & 0.15 \\
\hline Bidens frondosa & FACW & ANF & Both & 0.05 \\
\hline Calamagrostis canadensis & FACW+ & PNG & NAs & 0.05 \\
\hline Carex bebbii & OBL & PNGL & NAs & 0.10 \\
\hline Carex normalis & FACU & PNGL & NAs & 0.10 \\
\hline Carex spp. & & & Both & 0.15 \\
\hline Ceratophyllum demersum & OBL & $\mathrm{PN} / \mathrm{F}$ & ROW & 0.05 \\
\hline Circaea lutetiana & FACU & PNF & ROW & 0.15 \\
\hline Eleocharis obtusa & OBL & APNEGL & ROW & 0.05 \\
\hline Erigeron annuus & FACU & ANF & NAs & 0.05 \\
\hline Eupatorium perfoliatum & $\mathrm{FACW}_{+}$ & PNF & Both & 0.08 \\
\hline Fragaria virginiana & FACU & PNF & NAs & 0.05 \\
\hline Fraxinus nigra & OBL & NETS & NAs & 0.10 \\
\hline Galium palustre & OEL & PNF & NAs & 0.25 \\
\hline Juncus canadensis & $\mathrm{OBL}$ & PNGL & NAs & 0.05 \\
\hline Lemna trisulca & OBL & $P N / F$ & Both & 43.9 \\
\hline Ludwegia palustris & OBL & PNEF & Both & 0.15 \\
\hline Lycopus americanus & OBL & PNF & NAs & 0.25 \\
\hline Lysimachia thyrsiflora & OBL & PIF & NAs & 0.10 \\
\hline Mimulus ringens & OBL & PNF & NAs & 0.10 \\
\hline Pilea pumila & FACW & ANF & NAs & 0.15 \\
\hline Plantago rugelii & FACU & PNF & NAs & 0.15 \\
\hline Poa pratensis & FACU & PNG & ROW & 0.05 \\
\hline Polygonum pensyivanicum & FACW & ANEF & NAs & 0.05 \\
\hline Potentilla norvegica & FACU & ABPNF & NAs & 0.10 \\
\hline Potamogeton pectinatus & OBL & PNEF & ROW & 0.25 \\
\hline Rorripa spp. & & & NAs & 0.10 \\
\hline Rumex spp. & & & NAs & 0.05 \\
\hline Sium suave & $\mathrm{OBL}$ & PNEF & Both & 0.43 \\
\hline Solanum dulcamara & FAC- & PIF & NAs & 0.25 \\
\hline Sparganium spp. & & & Both & 7.63 \\
\hline Taraxacum officinale & FACU- & PIF & NAs & 0.05 \\
\hline Trifolium repens & FACU- & PIF & NAs & 0.10 \\
\hline Typha $\times$ glauca & OBL & PNEF & Both & 12.8 \\
\hline Urtica dioica & FACU & PIF & NAs & 0.20 \\
\hline Verbena hastata & FACW+ & PNF & NAs & 0.10 \\
\hline Vicia cracca & UPL & NIF & NAs & 0.15 \\
\hline
\end{tabular}

a Plant characteristics and life-forms assigned to each species, as indicated in this column, are explained in Reed (1988). (See Appendix B, Section B.2, for definitions of life-form and origins.)

b The species' greatest percent coverage is in the herb stratum unless otherwise noted.

c Plant species occurred in both the NAs and the ROW. 
TABLE D.3 Plant Species Present in Study Plots in 1991 and 1992 - Scrub-Shrub Community

\begin{tabular}{|c|c|c|c|c|c|c|}
\hline \multirow[b]{2}{*}{ Species Scientific Name } & \multirow{2}{*}{$\begin{array}{l}\text { Wetland } \\
\text { Indicator } \\
\text { Category }\end{array}$} & \multirow{2}{*}{$\begin{array}{l}\text { Life- } \\
\text { Form/ } \\
\text { Origina }\end{array}$} & \multicolumn{2}{|c|}{ Occurrence } & \multicolumn{2}{|c|}{ Percent Coverage ${ }^{b}$} \\
\hline & & & 1991 & 1992 & 1991 & 1992 \\
\hline Acer rubrum & FAC & NT & Bothe & Both & 0.60 & $0.1 \quad\left(s^{*}\right)$ \\
\hline Acer saccharinum & FACW & NT & Both & Both & $13.5\left(t^{\star}\right)$ & 15.7 (sa*) \\
\hline Cornus amomum & FACW & NS & Both & NAs & $1.40(s)$ & 0.10 \\
\hline Cornus foemina & FAC & NS & Both & NAs & $4.50(\mathrm{~s})$ & 1.10 \\
\hline Cornus stolonifera & FACW+ & NS & Both & NAs & $0.73(\mathrm{~s})$ & $0.50(s)$ \\
\hline Fraxinus pennsylvanica & FACW & NT & Both & Both & $8.90(s)$ & $1.15(\mathrm{~s})$ \\
\hline Glyceria striata & OBL & PNEG & Both & Both & 0.10 & 0.15 \\
\hline Impatiens capensis & FACW & ANF & NAs & Both & 0.10 & 0.13 \\
\hline Juncus tenuis & FAC- & PNGL & Both & ROW & 0.08 & 0.15 \\
\hline Lemna minor & OBL & $\mathrm{PN} / \mathrm{F}$ & Both & Both & 97.3 & 37.4 \\
\hline Polygonum amphibium & OBL & PNE/F & Both & Both & 0.35 & 0.90 \\
\hline Salix bebbiana & FACW & NS & Both & NAs & $3.28(s)$ & $0.30(\mathrm{~s})$ \\
\hline Salix discolor & FACW & NS & Both & NAs & $12.2(\mathrm{~s})$ & $3.30(\mathrm{~s})$ \\
\hline Salix fragilis & $\mathrm{FAC}+$ & IT & Both & NAs & $4.60(t)$ & $12.1(t)$ \\
\hline Salix petiolaris & OBL & NS & Both & Both & $11.7(\mathrm{~s})$ & $5.10(s)$ \\
\hline Uimus americana & FACW- & NT & Both & Both & $5.75(\mathrm{~s})$ & $0.30\left(s^{*}\right)$ \\
\hline
\end{tabular}

a Plant characteristics and life-forms assigned to each species, as indicated in this column, are explained in Reed (1988). (See Appendix B, Section B.2, for definitions of life-forms and origins).

b The species' greatest percent coverage is in the herb stratum unless otherwise noted: $(s)=$ shrub; $\left(s^{*}\right)=$ shrub, NAs only; $(s a)=$ sapling; $\left(s^{*}\right)=$ sapling, NAs only; $(t)=$ tree; $\left(t^{*}\right)=$ tree, NAs only.

c Plant species occurred in both the NAs and the ROW. 
TABLE D.4 Plant Species Present in Study Plots in 1991 Only - Emergent Marsh Community

\begin{tabular}{lllll}
\hline Species Scientific Name & $\begin{array}{l}\text { Wetland } \\
\text { Indicator } \\
\text { Category }\end{array}$ & $\begin{array}{l}\text { Life } \\
\text { Form/ } \\
\text { Origin }\end{array}$ & Occurrence & $\begin{array}{c}\text { Percent } \\
\text { Coverage }^{\text {b }}\end{array}$ \\
\hline Acer rubrum & FAC & NT & Bothc & 0.08 \\
Anthoxanthum odoratum & FACU & PIG & NAs & 0.10 \\
Carex gracillima & FACU & PNG & Both & 0.23 \\
Carex lacustris & OBL & PNEG & NAs & 0.05 \\
Poa alodes & FACW- & PNG & Both & 3.63 \\
Salix fragilis & FAC+ & IT & Both & $4.00(\mathrm{t})$ \\
Stellaria graminea & FAC- & PNF & NAs & 0.05 \\
Viburnum dentatum & FAC & NST & NAs & $0.20(\mathrm{~s})$ \\
\hline
\end{tabular}

a Plant characteristics and life-forms assigned to each species, as indicated in this column, are explained in Reed (1988). (See Appendix B, Section B.2, for definitions of life-forms and origins).

b The species' greatest percent coverage is in the herb stratum unless otherwise noted: $(s)=$ shrub, $(t)=$ tree, ROW only.

c Plant species occurred in both the NAs and the ROW. 
TABLE D.5 Plant Species Present in Study Plots in 1992 Only - Emergent Marsh Community

\begin{tabular}{|c|c|c|c|c|}
\hline Species Scientific Name & $\begin{array}{l}\text { Wetland } \\
\text { Indicator } \\
\text { Category }\end{array}$ & $\begin{array}{l}\text { Life } \\
\text { Form/ } \\
\text { Origina }\end{array}$ & Occurrence & $\begin{array}{c}\text { Percent } \\
\text { Coverage }^{b}\end{array}$ \\
\hline Acer saccharinum & FACW & NT & NAs & 0.10 \\
\hline Acorus calamus & OBL & PIEF & ROW & 0.05 \\
\hline Agrostis stolonifera & FACW & PNG & Both & 0.33 \\
\hline Calamagrostis canadensis & FACW+ & PNG & Both & 0.08 \\
\hline Carex comosa & OBL & PNEGL & NAs & 0.25 \\
\hline Carex lasiocarpa & OBL & PNEGL & NAs & 0.05 \\
\hline Carex spp. & & & ROW & 1.25 \\
\hline Carex tenera & OBL & PNGL & NAs & 0.05 \\
\hline Dryopteris spinulosa & FAC+ & F3 & NAs & 0.05 \\
\hline Eleocharis spp. & & & Both & 0.58 \\
\hline Glyceria striata & OBL & PNEG & Both & 0.08 \\
\hline Juncus bufonius & FACW & ANGL & ROW & 1.10 \\
\hline Juncus canadensis & $\mathrm{OBL}$ & PNGL & ROW & 0.40 \\
\hline Leersia oryzoides & OBL & PNG & NAs & 3.15 \\
\hline Lemna minor & OBL & PN/F & Both & 0.15 \\
\hline Lemna trisulca & OBL & PN/F & ROW & 0.05 \\
\hline Lolium perenne & FACU- & $\mathrm{PIG}$ & ROW & 0.05 \\
\hline Oxalis europaea & UPL & PIF & NAs & 0.05 \\
\hline Phleum pratensis & FACU & PIG & NAs & 0.05 \\
\hline Poa palustris & FACW & PNG & NAs & 0.15 \\
\hline Polygonum pensylvanicum & FACW & ANEF & ROW & 0.15 \\
\hline Ranunculus sceleratus & $\mathrm{OBL}$ & APNEF & ROW & 0.10 \\
\hline Rumex spp. & & & NAs & 0.15 \\
\hline Solanum dulcamara & FAC- & PIF & NAs & 0.05 \\
\hline Toxicodendron radicans & FAC & NUVS & ROW & 0.10 \\
\hline Trifolium repens & FACU- & PIF & ROW & 0.30 \\
\hline
\end{tabular}

a Plant characteristics and life-forms assigned to each species, as indicated in this column, are explained in Reed (1988). (See Appendix B, Section B.2, for definitions of life-forms and origins).

b The species' greatest percent coverage is in the herb stratum unless otherwise noted.

c Plant species occurred in both the NAs and the ROW. 
TABLE D.6 Plant Species Present in Study Plots in Both 1991 and 1992 - Emergent Marsh Community

\begin{tabular}{|c|c|c|c|c|c|c|}
\hline \multirow[b]{2}{*}{ Species Scientific Name } & \multirow{2}{*}{$\begin{array}{l}\text { Wetland } \\
\text { Indicator } \\
\text { Category }\end{array}$} & \multirow{2}{*}{$\begin{array}{l}\text { Life- } \\
\text { Form/ } \\
\text { Origin }^{a}\end{array}$} & \multicolumn{2}{|c|}{ Occurrence } & \multicolumn{2}{|c|}{ Percent Coverage $^{b}$} \\
\hline & & & 1991 & 1992 & 1991 & 1992 \\
\hline Alisma plantago-aquatica & OBL & PNEF & Bothc & Both & 0.23 & 2.38 \\
\hline Asclepias incarnata & OBL & PNF & Both & NAs & 0.10 & 0.04 \\
\hline Bidens cernua & OBL & AlF & NAs & ROW & 0.05 & 0.40 \\
\hline Calystegia sepium & FAC- & PIF & ROW & NAs & 0.10 & 0.10 \\
\hline Carex bebbii & OBL & PNGL & NAs & NAs & 0.15 & 0.35 \\
\hline Carex crinita & $\mathrm{OBL}$ & PNEGL & Both & NAs & 0.35 & 0.50 \\
\hline Carex flava & OBL & PNGL & NAs & NAs & 0.10 & 0.05 \\
\hline Carex hystericina & OBL & PNEGL & NAs & NAs & 0.15 & 0.05 \\
\hline Carex lupulina & OBL & PNEGL & Both & NAs & 1.30 & 0.75 \\
\hline Carex normalis & FACU & PNGL & Both & NAs & 0.40 & 0.40 \\
\hline Carex pallescens & UPL & PNGL & Both & NAs & 0.30 & 0.05 \\
\hline Carex retrorsa & FACW+ & PNGL & NAs & NAs & 0.10 & 0.15 \\
\hline Carex scoparia & FACW & PNGL & NAs & NAs & 0.10 & 0.25 \\
\hline Carex suberecta & OBL & PNGL & Both & NAs & 0.05 & 0.10 \\
\hline Carex vulpinoidea & OBL & PNEGL & Both & Both & 0.33 & 0.10 \\
\hline Carex $\times$ stipata & OBL & PNGL & Both & NAs & 1.40 & 0.30 \\
\hline Cicuta bulbifera & $\mathrm{OBL}$ & PNF & Both & Both & 0.18 & 0.13 \\
\hline Cicuta maculata & OBL & PNF & Both & Both & 7.13 & 4.40 \\
\hline Cornus amomum & FACW & NS & Both & NAs & $10.5(\mathrm{~s})$ & $18.5(\mathrm{~s})$ \\
\hline Cornus foemina & FAC & NS & Both & NAs & $5.60(s)$ & $0.05(s)$ \\
\hline Cornus stolonifera & FACW+ & NS & Both & NAs & $17.0(\mathrm{~s})$ & $13.1(s)$ \\
\hline Epilobium hirsutum & FACW & PIF & Both & NAs & 0.55 & 0.10 \\
\hline Equisetum arvense & FAC & $\mathrm{PNH} 2$ & Both & NAs & 29.5 & 5.80 \\
\hline Equisetum fluviatile & OBL & $\mathrm{PNH} 2$ & Both & Both & 24.3 & 16.6 \\
\hline Eupatoriadelphus maculatus & FACW & PNF & Both & Both & 2.60 & 7.18 \\
\hline Eupatorium perfoliatum & FACW+ & PNF & Both & Both & 0.13 & 0.20 \\
\hline Fraxinus pennsylvanica & FACW & NT & Both & NAs & 0.05 & 0.15 (s) \\
\hline Galium palustre & OBL & PNF & Both & Both & 2.90 & 4.53 \\
\hline Impatiens capensis & FACW & ANF & Both & Both & 21.4 & 14.5 \\
\hline Iris versicolor & OBL & PNF & Both & Both & 1.30 & 0.68 \\
\hline Juncus tenuis & FAC- & PNGL & NAs & ROW & 0.01 & 0.10 \\
\hline Liparis loeselii & FACW & PNF & Both & NIPd & 0.05 & - \\
\hline Ludwegia palustris & $\mathrm{OBL}$ & PNEF & Both & ROW & 1.05 & 0.80 \\
\hline Lycopus americanus & OBL & PNF & Both & Both & 0.68 & 0.25 \\
\hline Lycopus uniflorus & OBL & PNF & Both & NIP & 0.83 & - \\
\hline Lysimachia nummularia & $\mathrm{OBL}$ & PIF & Both & NAs & 0.43 & 0.10 \\
\hline Lysimachia thyrsiflora & OBL & PIF & Both & NIP & 0.23 & - \\
\hline Mentha spp. & & & ROW & NIP & 0.10 & - \\
\hline Nasturtium officinale & OBL & PIZEF & Both & Both & 1.50 & 1.13 \\
\hline Onoclea sensibilis & FACW & PNEF3 & Both & NAs & 2.10 & 8.25 \\
\hline Poa pratensis & FACU & PNG & Both & Both & 1.13 & 0.63 \\
\hline Ranunculus acris & $\mathrm{FAC}+$ & PIF & Both & Both & 0.45 & 0.10 \\
\hline Rhamnus cathartica & UPL & is & Both & NAs & 4.90 (s) & 6.05 (s) \\
\hline Salix discolor & FACW & NS & NAs & NAs & $1.30(\mathrm{~s})$ & $3.10(\mathrm{~s})$ \\
\hline Salix petiolaris & OBL & NS & Both & Both & 12.2 (s) & $9.20\left(\mathrm{~s}^{*}\right)$ \\
\hline
\end{tabular}


TABLE D.6 (Cont.)

\begin{tabular}{|c|c|c|c|c|c|c|}
\hline \multirow[b]{2}{*}{ Species Scientific Name } & \multirow{2}{*}{$\begin{array}{l}\text { Wetland } \\
\text { Indicator } \\
\text { Category }\end{array}$} & \multirow{2}{*}{$\begin{array}{l}\text { Life- } \\
\text { Form/ } \\
\text { Origin }\end{array}$} & \multicolumn{2}{|c|}{ Occurrence } & \multicolumn{2}{|c|}{ Percent Coverage ${ }^{\mathrm{b}}$} \\
\hline & & & 1991 & 1992 & 1991 & 1992 \\
\hline Scirpus atrovirens & $\mathrm{OBL}$ & PNEGL & Both & NAs & 0.73 & 0.75 \\
\hline Scirpus validus & $\mathrm{OBL}$ & PNEGL & NAs & NAs & 0.40 & 0.30 \\
\hline Solidago spp. (narrow If.) & & & Both & Both & 0.31 & 0.31 \\
\hline Solidago spp. (wide If.) & & & Both & Both & 2.40 & 2.38 \\
\hline Typha $\times$ glauca & OBL & PNEF & Both & Both & 67.8 & 34.2 \\
\hline Ulmus americana & FACW- & NT & NAs & NAs & 0.05 & 0.05 \\
\hline Viburnum lentago & FAC & NTS & NAs & NAs & 0.20 (s) & 0.05 (s) \\
\hline Vicia cracca & UPL & NIF & Both & NAs & 0.50 & 2.15 \\
\hline
\end{tabular}

a Plant characteristics and life-forms assigned to each species, as indicated in this column, are explained in Reed (1988). (See Appendix B, Section B.2, for definitions of life-forms and origins).

b The species' greatest percent coverage is in the herb stratum unless otherwise noted: $(s)=$ shrub.

c Plant species occurred in both the NAs and the ROW.

d NIP $=$ not in plots 
TABLE D.7 Plant Species Present in Study Plots in 1991 Only - Forested Wetland Community

\begin{tabular}{|c|c|c|c|c|}
\hline Species Scientific Name & $\begin{array}{l}\text { Wetland } \\
\text { Indicator } \\
\text { Category }\end{array}$ & $\begin{array}{l}\text { Life- } \\
\text { Form/ } \\
\text { Origina }\end{array}$ & Occurrence & $\begin{array}{c}\text { Percent } \\
\text { Coverage }^{b}\end{array}$ \\
\hline Acer rubrum & FAC & NT & Both $\mathrm{c}$ & $40.0 \quad\left(t^{*}\right)$ \\
\hline Carex brunnescens & FACW & PNGL & Both & 1.25 \\
\hline Carex gracillima & FACU & PNGL & ROW & 1.50 \\
\hline Cornus foemina & FAC & NS & NAs & $10.0(\mathrm{~s})$ \\
\hline Fragaria spp. & & & NAs & 1.00 \\
\hline Lonicera tartarica & FACU & IS & Both & 0.63 \\
\hline Poa alsodes & FACW & PNG & Both & 10.5 \\
\hline Poa pratensis & FACU & PNG & NAs & 1.00 \\
\hline Populus deltoides & FAC & NT & NAs & $10.0(t)$ \\
\hline Ranunculus acris & FAC+ & PIF & Both & 0.50 \\
\hline Solidago spp. & & & Both & 2.50 \\
\hline Viburnum lentago & FAC & NTS & ROW & 1.00 \\
\hline Viola spp. & & & NAs & 0.50 \\
\hline
\end{tabular}

a Plant characteristics and life-forms assigned to each species, as indicated in this column, are explained in Reed (1988). (See Appendix B, Section B.2, for definitions of life-forms and origins).

b The species' greatest percent coverage is in the herb stratum unless otherwise noted: $(s)=$ shrub; $(t)=$ tree; $\left(t^{*}\right)=$ tree, NAs only.

c Plant species occurred in both the NAs and the ROW. 
TABLE D.8 Plant Species Present in Study Plots in 1992 Only - Forested Wetland Community

\begin{tabular}{|c|c|c|c|c|}
\hline Species Scientific Name & $\begin{array}{l}\text { Wetland } \\
\text { Indicator } \\
\text { Category }\end{array}$ & $\begin{array}{l}\text { Life-Form/ } \\
\text { Origin }^{\mathbf{a}}\end{array}$ & Occurrence & $\begin{array}{c}\text { Percent } \\
\text { Coverage }^{b}\end{array}$ \\
\hline Acer saccharinum & FACW & NT & Bothc & $40.0 \quad\left(t^{*}\right)$ \\
\hline Acorus calamus & OBL & PIEF & Both & 0.25 \\
\hline Alisma plantago-aquatica & OBL & PNEF & Both & 0.25 \\
\hline Ambrosia artemisiifolia & FACU & ANF & ROW & 0.25 \\
\hline Aster spp. & & & NAs & 0.50 \\
\hline Bidens cermua & OBL & AlF & Both & 0.88 \\
\hline Bidens frondosa & FACW & ANF & Both & 0.38 \\
\hline Caltha palustris & OBL & PNF & NAs & 0.25 \\
\hline Carex bromoides & FACW & PNGL & NAs & 0.25 \\
\hline Carex flava & OBL & PNGL & NAs & 0.50 \\
\hline Carex lupulina & OBL & PNEGL & NAs & 0.50 \\
\hline Carex normalis & FACU & PNGL & NAs & 0.25 \\
\hline Cicuta bulbifera & $\mathrm{OBL}$ & PNF & Both & 0.25 \\
\hline Cicuta maculata & OBL & PNF & NAs & 0.25 \\
\hline Cinna arundinacea & FACW+ & PNG & NAs & 0.25 \\
\hline Circeae lutetiana & FACU & PNF & NAs & 0.25 \\
\hline Cornus amomum & FACW & NS & Both & 0.25 \\
\hline Dryopteris spinulosa & $\mathrm{FAC}+$ & F3 & NAs & 0.25 \\
\hline Eleocharis obrusa & $\mathrm{OBL}$ & APNEGL & ROW & 0.25 \\
\hline Equisetum arvense & FAC & PNH2 & NAs & 0.25 \\
\hline Galium plaustre & OBL & PNF & Both & 0.25 \\
\hline Juncus tenuis & FAC- & PNGL & NAs & 0.25 \\
\hline Lemna minor & $\mathrm{OBL}$ & $\mathrm{PN} / \mathrm{F}$ & ROW & 0.25 \\
\hline Lemna trisulca & OBL & $\mathrm{PN} / \mathrm{F}$ & ROW & 0.25 \\
\hline Lilium philadelphium & FACU+ & PNF & NAs & 0.25 \\
\hline Lolium perenne & FACU- & $\mathrm{PIG}$ & Both & 1.13 \\
\hline Ludwegia palustris & OBL & PNEF & Both & 0.25 \\
\hline Lycopus americanus & OBL & PNF & NAs & 0.25 \\
\hline Medicago lupulina & UPL & PIF & ROW & 0.25 \\
\hline Poa palustris & FACW & PNG & NAs & 0.25 \\
\hline Quercus bicolor & FACW+ & NT & NAs & $1.00(t)$ \\
\hline Rhamnus cathartica & UPL & IS & NAs & $11.5(\mathrm{~s})$ \\
\hline Rhamnus frangula & FAC & is & NAs & 0.50 \\
\hline Ribes cyanosbata & UPL & NS & NAs & 0.25 \\
\hline Rosa palustris & OBL & NS & NAs & 0.25 \\
\hline Rubus strigosus & $\mathrm{NI}$ & PNS & NAs & 0.50 \\
\hline Salix fragilis & FAC+ & IT & Both & $20.0 \quad\left(t^{*}\right)$ \\
\hline Sambucus canadensis & FACW- & NS & NAs & 0.25 \\
\hline Solanum dulcamara & FAC- & PIF & NAs & 0.25 \\
\hline Sorbus americana & FACU & NT & NAs & 0.50 \\
\hline Sparganium sp & & & NAs & 1.00 \\
\hline Thalictrum pubescens & FACW+ & PNF & NAs & 0.25 \\
\hline
\end{tabular}


TABLE D.8 (Cont.)

\begin{tabular}{lllll}
\hline Species Scientific Name & $\begin{array}{c}\text { Wetland } \\
\text { Indicator } \\
\text { Category }\end{array}$ & $\begin{array}{c}\text { Life-Form/ } \\
\text { Origina }\end{array}$ & Occurrence & $\begin{array}{c}\text { Percent } \\
\text { Coverage }^{b}\end{array}$ \\
\hline Trifolium repens & FACU- & PIF & ROW & 0.25 \\
Typha latifolia & OBL & PNEF & NAs & 1.00 \\
Typha $\times$ glauca & OBL & PNEF & Both & 5.13 \\
Viburnum recognitum & FACW- & NS & NAs & 0.75 \\
\hline
\end{tabular}

a Plant characteristics and life-forms assigned to each species, as indicated in this column, are explained in Reed (1988). (See Appendix B, Section B.2, for definitions of life-forms and origins).

b The species' greatest percent coverage is in the herb stratum unless otherwise noted: $(s)=$ shrub, $(t)=$ tree, $\left(t^{\star}\right)=$ tree, NAs only.

c Plant species occurred in both the NAs and the ROW. 
TABLE D.9 Plant Species Present in Study Plots in 1991 and 1992 - Forested Wetland Community

\begin{tabular}{|c|c|c|c|c|c|c|}
\hline \multirow[b]{2}{*}{ Species Scientific Name } & \multirow{2}{*}{$\begin{array}{l}\text { Wetland } \\
\text { Indicator } \\
\text { Category }\end{array}$} & \multirow{2}{*}{$\begin{array}{l}\text { Life- } \\
\text { Form/ } \\
\text { Origina }^{\text {a }}\end{array}$} & \multicolumn{2}{|c|}{ Occurrence } & \multicolumn{2}{|c|}{ Percent Coverage ${ }^{b}$} \\
\hline & & & 1991 & 1992 & 1991 & 1992 \\
\hline Arisaema triphyllum & FACW- & PNF & Both $^{c}$ & NAs & 0.88 & 0.25 \\
\hline Athyrium filix-femina & FAC & PNF3 & Both & NAs & 3.25 & 0.25 \\
\hline Carex bebbii & OBL & PNGL & ROW & NAs & 0.25 & 0.25 \\
\hline Carex crinita & OBL & PNEGL & ROW & NAs & 0.50 & 0.25 \\
\hline Fraxinus pennys/vanica & FACW & NT & Both & NAs & 10.0 & 1.75 \\
\hline Geum canadense & FACU & PNF & Both & NAs & 0.75 & 0.25 \\
\hline Glyceria striata & OBL & PNEG & Both & Both & 1.75 & 2.90 \\
\hline Impatiens capensis & FACW & ANF & Both & Both & 23.8 & 2.50 \\
\hline Lonicera tatarica & $\mathrm{FACU}_{+}$ & is & Both & NAs & 0.63 & 0.50 \\
\hline Onoclea sensibilis & FACW & PNEF3 & Both & NAs & 2.00 & 12.8 \\
\hline Parthenocisscus quinquefolia & FACU & $\mathrm{NWW}$ & Both & NAs & 3.50 & 1.75 \\
\hline Pilea pumila & FACW & ANF & Both & NAs & 0.75 & 0.50 \\
\hline Rhamnus catharticus & UPL & IS & Both & NAs & $28.0(\mathrm{~s})$ & $11.5(\mathrm{~s})$ \\
\hline Ribes americana & FACW & NS & Both & NAs & 2.00 & 0.75 \\
\hline Rubus pubescens & FACW & PNF & Both & NAs & 3.50 & 2.00 \\
\hline Toxicodendron radicans & FAC & NWWS & NAs & NAs & 1.00 & 2.25 \\
\hline Ulmus americana & FACW- & NT & Both & Both & $5.00\left(t^{*}\right)$ & $1.00\left(\mathrm{~s}^{*}\right)$ \\
\hline Viburnum dentatum & FAC & NTS & Both & NAs & 0.38 & 0.25 \\
\hline Vitis riparia & FACW & NWW & ROW & NAs & 1.00 & 0.25 \\
\hline
\end{tabular}

a Plant characteristics and life-forms assigned to each species, as indicated in this column, are explained in Reed (1988). (See Appendix B, Section B.2, for definitions of life-forms and origins).

b The species' greatest percent coverage is in the herb stratum unless otherwise noted; $(s)=$ shrub; $\left(s^{*}\right)=$ shrub, NAs only; $\left(t^{*}\right)=$ tree, NAs only.

c Plant species occurred in both the NAs and the ROW. 